OCEAN DRILLING PROGRAM

LEG 143 PRELIMINARY REPORT

NORTHWEST PACIFIC ATOLLS AND GUYOTS

\author{
Dr. Edward L. Winterer \\ Co-Chief Scientist, Leg 143 \\ Scripps Institution of Oceanography \\ La Jolla, California 92092-0212
}

Dr. William W. Sager

Co-Chief Scientist, Leg 143

Department of Oceanography

Texas A\&M University

College Station, Texas 77843-3146

Dr. John Firth

Staff Scientist, Leg 143

Ocean Drilling Program

Texas A\&M University Research Park

1000 Discovery Drive

College Station, Texas 77845-9547

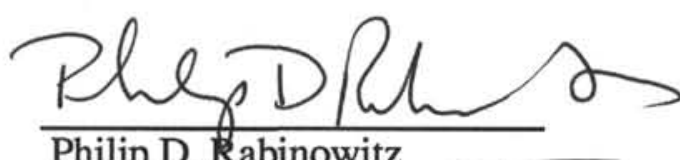

Philip D. Rabinowitz

Director

ODP/TAMU

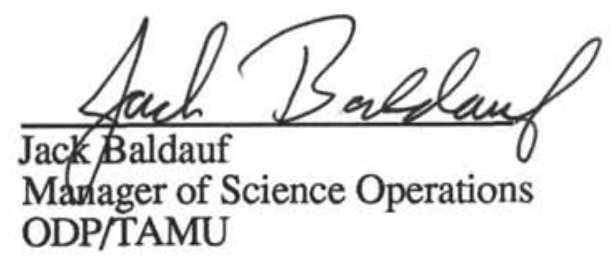

19G Dranai

Timothy J.G. Francis

Deputy Director

ODP/TAMU

August 1992 
This informal report was prepared from the shipboard files by the scientists who participated in the cruise. The report was assembled under time constraints and is not considered to be a formal publication which incorporates final works or conclusions of the participating scientists. The material contained herein is privileged proprietary information and cannot be used for publication or quotation.

\section{Preliminary Report No. 43}

First Printing 1992

\section{Distribution}

Copies of this publication may be obtained from the Director, Ocean Drilling Program, Texas A\&M University Research Park, 1000 Discovery Drive, College Station, Texas 77845-9547. In some cases, orders for copies may require payment for postage and handling.

\section{I $\underline{\mathrm{C}} \underline{\mathrm{L}} \underline{\mathrm{A}} \underline{\mathrm{M}} \underline{\mathrm{E}} \underline{\mathrm{R}}$}

This publication was prepared by the Ocean Drilling Program, Texas A\&M University, as an account of work performed under the international Ocean Drilling Program, which is managed by Joint Oceanographic Institutions, Inc., under contract with the National Science Foundation. Funding for the program is provided by the following agencies:

Academy of Sciences (Russia)

Canada/Australia Consortium for the Ocean Drilling Program

Deutsche Forschungsgemeinschaft (Federal Republic of Germany)

Institut Français de Recherche pour l'Exploitation de la Mer (France)

Ocean Research Institute of the University of Tokyo (Japan)

National Science Foundation (United States)

Natural Environment Research Council (United Kingdom)

European Science Foundation Consortium for the Ocean Drilling Program

(Belgium, Denmark, Finland, Greece, Iceland, Italy, The Netherlands, Norway, Spain, Sweden, Switzerland, and Turkey)

Any opinions, findings, and conclusions or recommendations expressed in this publication are those of the author(s) and do not necessarily reflect the views of the National Science Foundation, the participating agencies, Joint Oceanographic Institutions, Inc., Texas A\&M University, or Texas A\&M Research Foundation. 
SCIENTIFIC REPORT 
Leg 143

Preliminary Report

Page 4

The scientific party aboard JOIDES Resolution for Leg 143 of the Ocean Drilling Program consisted of:

Edward L. Winterer, Co-Chief Scientist (Scripps Institution of Oceanography, University of California, San Diego, La Jolla, California 92093-0220)

William W. Sager, Co-Chief Scientist (Department of Oceanography, Texas A\&M University, College Station, Texas 77843-3146)

John Firth, ODP Staff Scientist (Ocean Drilling Program, Texas A\&M University Research Park, 1000 Discovery Drive, College Station, Texas 77845-9547)

Hubert M. Arnaud (Institut Dolomieu, Rue Maurice Gignoux, 38031 Grenoble Cedex, France)

Peter E. Baker (Department of Earth Sciences, University of Leeds, Leeds LS2 9JT, United Kingdom)

François Baudin (Laboratoire de Stratigraphie, Université Pierre et Marie Curie, 4 place Jussieu, 75252 Paris Cedex 05, France)

Timothy Bralower (Geology Department, University of North Carolina, CB\# 3315 Mitchell Hall, Chapel Hill, North Carolina 27599-3315)

Paterno Castillo (Geological Research Division, Scripps Institution of Oceanography, University of California, San Diego, La Jolla, California 92093-0220)

Patricia A. Cooper (Geology and Geophysics Department, School of Ocean and Earth Science and Technology, University of Hawaii, 2525 Correa Road, Honolulu, Hawaii 96822)

Peter G. Flood (Geology Department, University of New England, Armidale, NSW 2351, Australia)

Xenia Golovchenko (Borehole Research Group, Lamont-Doherty Geological Observatory, Columbia University, Palisades, New York 10964)

Yasufumi Iryu (Institute of Geology and Paleontology, Faculty of Science, Tohoku University, Aobayama, Sendai 980, Japan)

Mikhail K. Ivanov (Moscow State University, Geological Faculty, Leninskie Gory MGU, Moscow 117234, Russia)

Hugh C. Jenkyns (Department of Earth Sciences, University of Oxford, Oxford OX1 3PR, United Kingdom) 
Leg 143

Preliminary Report

Page 5

Jeroen A.M. Kenter (As of 1 July 1992: Department of Earth Sciences, Free University,

De Boelelaan 1085, 1081 HV Amsterdam, The Netherlands. Currently at:

RSMAS/MGG, University of Miami, 4600 Rickenbacker Causeway, Miami, Florida 33149)

Ivar O. Murdmaa (P.P. Shirshov Institute of Oceanology, U.S.S.R. Academy of Sciences, Krasikova st. 23, 117218 Moscow, Russia)

Jörg Mutterlose (Institut für Geologie und Paläontologie, Universität Hannover, Callinstrasse 30, D-3000 Hannover 1, Federal Republic of Germany)

Yoshifumi Nogi (Geochemical Laboratory, Meteorological Research Institute, Tsukuba, Ibaraki 305, Japan)

Charles K. Paull (University of North Carolina, CB\# 3315 Mitchell Hall, Chapel Hill, North Carolina 27599-3315)

Evelyn Polgreen (Department of Oceanography, Texas A\&M University, College Station, Texas 77843-3146)

Ursula Röhl (Bundesanstalt für Geowissenschaften und Rohstoffe, Stilleweg 2, D-3000 Hannover 51, Federal Republic of Germany)

William V. Sliter (U.S. Geological Survey, Branch of Paleontology, MS 915, 345

Middlefield Road, Menlo Park, California 94025)

André Strasser (Institute of Geology, University of Fribourg, Pérolles, 1700 Fribourg, Switzerland)

Nicola H.M. Swinburne (University of California, Berkeley, Department of Geology/Geophysics, Berkeley, California 94720)

John A. Tarduno (Geological Research Division, Scripps Institution of Oceanography, University of California, San Diego, La Jolla, California 92093-0220)

Robert van Waasbergen (Scripps Institution of Oceanography, University of California, San Diego, La Jolla, California 92093-0220) 
Leg 143

Preliminary Report

Page 7

\begin{abstract}
Leg 143 drilled on the summits of two guyots in the Mid-Pacific Mountains (Sites 865, 866, and 867/868), the archipelagic apron adjacent to an atoll-guyot pair in the Marshall Islands (Site 869), and within the lagoon of a modern Marshall Islands atoll (Site 870). Scientific party objectives were to study the development, growth, and drowning of Cretaceous Pacific carbonate platforms, to examine their record of sea-level change, and to decipher the tectonic and volcanic history of these edifices. At Site 870, the purpose was mainly a test of the shallow-water drilling capability of JOIDES Resolution.
\end{abstract}

Deep holes drilled into the Cretaceous lagoonal limestones of Allison (Hole 865A) and Resolution (previously named Huevo; Holes 866A and 866B) Guyots yielded thick, shallow-water limestone caps that record the histories of the guyots from the submergence of the volcanic pedestal through the final drowning of the carbonate platform. Both guyots have alternated between subsidence and uplift, with Resolution Guyot having an additional chapter in its history owing to its greater age. The carbonate platform on Resolution formed during the Barremian, on a small, rapidly subsiding volcanic pedestal. It quickly accumulated about $1350 \mathrm{~m}$ of carbonate sediments by early to middle Aptian time. After a hiatus of perhaps as great as 10-15 m.y., during which time the carbonate platform either drowned with currents sweeping the summit clear of pelagic sediment or was uplifted and eroded, approximately $270 \mathrm{~m}$ of late Albian sediments accumulated above. Allison Guyot formed during late Albian time and it also accumulated a late Albian shallow-water limestone cap, $731 \mathrm{~m}$ of which were drilled on Leg 143. Despite the rapid subsidence of both guyots, their lagoonal facies sediments indicate very shallow water throughout most of the carbonate platform histories. Furthermore, the limestone sections are in many places characterized by meter-scale facies shifts that imply short-period cycles of emergence and submergence. Cores from both guyot summits also show evidence of dissolution and mineralization (by manganese and phosphate), indicating emergence and karsting at some time after the late Albian. Pelagic sediments infilling dissolution cavities from Hole 866B imply that this event occurred before mid-Turonian time. Drilling results and guyot morphology indicate that the relative sea-level drop was at least $160 \mathrm{~m}$.

Holes drilled into (867A and 867B) and next to (868A) the perimeter mound surrounding the summit on Resolution Guyot failed to find the expected abundant reefal material, suggesting that these mounds, commonly seen on guyot profiles, are not necessarily reefs like those on Cenozoic 


\section{Leg 143}

Preliminary Report

Page 8

atolls. These results point out important differences between Cretaceous and Cenozoic atolls - the latter were probably more open platforms with low relief.

An entirely different geologic history was recorded at Site 869 , on the apron adjacent to the atollguyot pair, Pikinni and Wodejebato. At this site, surprisingly little shallow-water debris was encountered. Instead, an abundance of volcaniclastic material was delivered to the site by turbidity currents, grain flows, and mass flows from late Cenomanian to Maastrichtian time. Especially large influxes during the Cenomanian and Campanian imply the existence of nearby land and shallow-water carbonate shoals at that time. During the Cenozoic, volcanism ceased and pelagic sedimentation prevailed, interrupted by turbidity currents carrying debris from shallow water.

\section{INTRODUCTION}

Across the western Pacific Ocean are scattered scores of Cretaceous seamounts (Menard, 1964; 1984a; Matthews et al., 1974). Their source is uncertain, but may have been a large-scale intraplate volcanic episode (Schlanger et al., 1981; Menard, 1984a; Winterer and Metzler, 1984) perhaps related to overturn in the mantle (Tarduno et al., 1991; Larson, 1991). Many of these seamounts have flat summits and are called "guyots" (Hess, 1946); still others are surmounted by modern atolls. Though some guyots may have formed by wave plantation (e.g., Menard, 1984b), many clearly have limestone caps. Because of this and morphologic resemblances to modern atolls (e.g., Ladd et al., 1974), the classic Darwinian model for atoll formation (Darwin, 1842) has often been extended to account for the formation of Cretaceous guyots. For reasons unknown, the atoll reefs apparently were unable to grow apace with the subsidence of the underlying edifice and so they drowned.

A corollary of the idea that guyot summits are created by waves or reefs is that they must have been at sea level. They can be thought to be giant "dipsticks" that measure the depth of the ocean at the time they drowned (Wheeler and Aharon, 1991). Indeed, this idea has been used in the western Pacific to connect guyot summits of the same depth and infer a large region of Cretaceous uplift, termed the "Darwin Rise" (Menard, 1984a). Guyot sediments may also give records of sea level during their formation. Their sediments are usually deposited close to sea level and thus record relative sea level rises and falls caused by subsidence or uplift in addition to fluctuations of eustatic sea level. Shifting climates also leave their imprints on the biota, facies, compositions, and textures 
Leg 143

Preliminary Report

Page 9

of guyot carbonates. Consequently, drilling of guyots offers the promise of answering fundamental questions about Cretaceous climate, sea level, biotic assemblages, and tectonics.

Leg 143 was the first of two Ocean Drilling Program (ODP) legs whose purpose was to drill atolls and guyots of the western Pacific. Eight atolls and guyots and one site on an archipelagic apron were to be drilled on Legs 143 and 144 , spanning nearly $35^{\circ}$ of longitude and $30^{\circ}$ of latitude. Provinces to be sampled were the mid-Pacific Mountains, Marshall Islands, Marcus-Wake Guyots, and Japanese guyots. Two-thirds of the time for Leg 143 were concentrated on two guyots in the mid-Pacific Mountains (Fig. 1), Allison (Site 865), and Resolution (Sites 866 and 867/868). The remainder of the time was spent in the Marshall Islands, where Site 869 was drilled in the basin adjacent to Wodejebato Guyot (formerly Sylvania) and Pikinni Atoll (formerly Bikini) and Site 870 was drilled in the lagoon of Anewetak Atoll (formerly Eniwetak) as a test of shallow-water drilling capability of JOIDES Resolution.

\section{Drilling Objectives}

Leg 143, drilling the limestone pedestals and pelagic caps of the guyots in the Mid-Pacific Mountains, had the following goals:

- To develop a history of Cretaceous carbonate platform growth and evolution by determining the lithologic, biostratigraphic, isotopic, geochemical, and seismic stratigraphic succession within the limestone cap, for comparison with other northwest Pacific guyots and with eustatic sea-level curves developed from other regions;

- To provide constraints on the timing and cause(s) of reef platform drowning;

- To examine the timing and extent of the emergence and karstification event(s) evident in the morphology and in seismic reflection profiles of Allison, Resolution, and other western Pacific guyots;

- To recover the oldest and deepest lagoonal sediments, providing constraint on the age of platform formation;

- To study the diagenetic history of guyot platform carbonates;

- To compare the shallow-water reef biotic assemblages to others of similar age elsewhere as a clue to migration patterns; 
Leg 143

Preliminary Report

Page 10

- To gather pore water samples, to infer residence times and chemical evolution of interstitial waters;

- To examine pelagic sediments, deposited above the CCD atop the guyots, for Late Cretaceous and Paleogene stable isotope and biostratigraphic data as well as additional constraints on the timing of platform drowning;

- To obtain a suite of downhole logs that would illuminate the structure, stratigraphy, and composition of the carbonate cap and upper volcanic layers of a guyot; and

- To collect data on seismic wave velocities in Cretaceous platform carbonates to use in the interpretation and correlation of seismic reflection and refraction data from Pacific guyots.

At Resolution Guyot (Sites 866-868), the drilling of the volcanic pedestal of the guyot addressed these additional goals:

- To determine a reliable Early Cretaceous paleolatitude for constraining the tectonic history of the guyot and the Pacific plate as a whole;

- To obtain a reliable radiometric date for the volcanic pedestal for evidence of the timing of volcanism in the Mid-Pacific Mountains;

- To compare geochemical and isotopic signatures of the guyot's basalts to those of other seamounts for evidence of the magma source; and

- To assess the long-term history of the Dupal isotopic anomaly in the Pacific.

Drilling in the basin adjacent to Wodejebato (formerly "Sylvania") Guyot (Site 869 in the Marshall Islands) also addressed the following specific goals:

- To calculate paleolatitudes for constraining the tectonic history of the Marshall Islands and the Pacific plate;

-To refine the magnetic polarity reversal time scale for the Early to Late Cretaceous;

-To study the diagenetic history of deep-water sediments;

-To determine seismic wave velocities in Cretaceous to Tertiary deep sea sediments for use in interpretation and correlation of seismic reflection and refraction data;

-To obtain a suite of downhole logs that illuminate the structure, stratigraphy, and composition of deep-sea sediments in the vicinity of atolls and guyots;

-To determine the history of volcanism on nearby Pikinni Atoll and Wodejebato Guyot; 
Leg 143

Preliminary Report

Page 11

-To develop a model of Cretaceous, mid-ocean guyot/atoll carbonate platform formation and evolution for the Marshall Islands; and

-To decipher the cause(s) for the drowning(s) of some Marshall Islands guyots (such as Wodejebato) versus the existence of Cenozoic reefs on nearby atolls (such as Pikinni).

\section{RESULTS *}

\section{Site 865}

Site 865 (proposed site All-A) is located at $18^{\circ} 26.41^{\prime} \mathrm{N}, 179^{\circ} 33.34 \mathrm{~W}$, at a water depth of 1518.4 mbsl atop Allison Guyot in the central Mid-Pacific Mountains (Figs. 1, 2, and 3). Allison is typical of Mid-Pacific Mountain guyots because it has a thick limestone cap with a seismic reflection signature that implies a sequence of ponded lagoonal sediments enclosed by a perimeter reef. Additionally, the limestones are surmounted by a thick cap of pelagic sediments to provide a post-drowning history.

Pre-Leg 143 site survey seismic profiles showed several prominent and many minor reflectors beneath the surface of the guyot. Strong reflections below the seafloor were thought to represent the top of shallow-water limestone and volcanic basement. Between these reflectors are a series of lesser seismic horizons that may have resulted from sea-level oscillations, and beneath the "basement" reflector are several additional weak returns that suggested layered volcanics, or interlayered sediments and volcanics.

Although the pre-cruise plan was to drill a single hole, three holes were drilled at Site 865. Hole $865 \mathrm{~A}$ was the primary deep hole, drilled using a single RCB bit. APC (Advanced Piston Corer) coring was postponed for use in Holes $865 \mathrm{~B}$ and $865 \mathrm{C}$ because it was feared that hard chert layers were present in the pelagics. Hole 865A penetrated $139.7 \mathrm{~m}$ of pelagic sediments ranging from late Paleocene to Quaternary age, but containing an expanded upper Paleocene to upper Eocene section. Core recovery through the pelagic section averaged $52 \%$, but the sediments were pervasively disturbed by rotary coring. Below 139.7 mbsf, upper Albian shallow-water limestones were drilled to within a few meters of the bottom of the hole, at $870.9 \mathrm{mbsf}$. Basalt intrusives interlayered with limestone were recovered in the last five cores, from $837.6 \mathrm{mbsf}$ to TD (total depth). Recovery in much of the shallow-water limestone section was low (1\%-2\%); however, it 
Leg 143

Preliminary Report

Page 12

improved notably (10\%-100\%) in the clayey limestones and basalts within the lowermost $100 \mathrm{~m}$ of the hole. Holes $865 \mathrm{~B}$ and $865 \mathrm{C}$ were $\mathrm{APC} / \mathrm{XCB}$ cored to obtain the expanded Paleocene-Eocene pelagic cap sediments for paleoceanographic and biostratigraphic study. Hole $865 \mathrm{~B}$ penetrated $141.5 \mathrm{~m}$ of pelagic sediments and an additional $24.0 \mathrm{~m}$ of mineralized limestone, to a total depth of $165.5 \mathrm{~m}$. Hole $865 \mathrm{C}$ extended to $136.3 \mathrm{mbsf}$ and was drilled with the APC only.

\section{Lithostratigraphy}

Using combined micro- and macro-fossil biostratigraphy, visual core descriptions augmented with smear-slide and thin section data, physical properties data, and downhole logging data, four principal stratigraphic units were distinguished (Fig. 4; Note: boundary depths given to tenths of meters were determined from cores; integer depths determined from logs). In stratigraphic order (from the bottom upward) these are as follows:

Unit IV (870.9-621.9 mbsf). Upper Albian clayey organic-rich limestone with decreasing amounts of clay and organic matter upward. Limestone layers contain a varied biota of benthic foraminifers, ostracodes, snails, bivalves, solitary corals, sponges, and dasycladacean and red algae. Mudstone beds are commonly extensively burrowed. Pyrite is common in dark-colored clay layers, and gypsum has been identified in several clay layers. Carbonaceous fragments of land plants are common, particularly near the bottom of the hole, and decrease in abundance upward. The lowest $30 \mathrm{~m}$ of the drilled section contains alkali basalt that is thought to be one or more sills, intruded into the sediments, rather than volcanic basement. Lithologic subunits IVD (870.9-837.6 mbsf), IVC (837.6-737.7 mbsf), IVB (737.7-660.4 mbsf), and IVA (660.4-621.9 mbsf) were distinguished based on varying amounts of clay, organic matter, dolomite, and bioclastic debris. Good core recovery $(10-100 \%)$ in the unit allowed recognition of depositional shallowing-upward cycles, repeating on a scale of about half a meter. These cycles were shown exceptionally well on the formation microscanner (FMS) logs, which could be matched very satisfactorily with the cores themselves in many intervals.

Unit III (621.9-207.3 mbsf). Upper Albian white limestones of several facies: peloidal mudstone, wackestone, packstone, and rare grainstone with molds of formerly aragonitic 
Leg 143

Preliminary Report

Page 13

mollusks. High-spired gastropods, small bivalves, sponges, and large sponge spicules are common; benthic foraminifers are relatively abundant; and ostracodes and dasycladacean algae occur sporadically. Rudists and corals occur in a few layers. Subunit IIIB (621.9$361.2 \mathrm{mbsf}$ ) is richer in lime mud than the overlying Subunit IIIA (361.2-207.3 mbsf). Induration is variable, and the limestone ranges from chalky to hard. Dissolution has removed most molluscan shells. Episodic subaerial exposure is suggested by the occurrence of erosional surfaces, reddish stains, and brecciated well-indurated wackestones. The FMS logs show a continuation of the cyclic alternations seen in Unit IV.

Unit II (207.3-139.7 mbsf). Upper Albian phosphatized, karstified limestone, riddled in the upper $40 \mathrm{~m}$ with internal cavities encrusted with phosphatic pelagic limestone and manganese oxyhydroxides (Subunit IIA). The cavities are partly filled with geopetal sediment containing Late Cretaceous nannofossils and planktonic foraminifers. The upper part of Subunit IIB is genetically like Unit III below it except for the mineralization. Unit II is silicified at the very top and shows concentrations of uranium on the downhole logs.

Unit I (139.7-0 mbsf). Middle Paleocene/Quaternary foraminiferal nannofossil ooze and foraminiferal sand. Approximately $90 \%$ of this section is of middle Paleocene to late Eocene age and probably formed as the guyot drifted beneath the equatorial high productivity zone. These sediments generally contain a large fraction of sand-sized foraminifers, suggesting winnowing by currents.

The pelagic sections at Site 865 had good recovery, averaging 52\%, 90\%, and $84 \%$ for Holes $865 \mathrm{~A}, 865 \mathrm{~B}$, and $865 \mathrm{C}$, respectively. Core recovery in the shallow-water limestones of Holes $865 \mathrm{~A}$ and $865 \mathrm{~B}$ was disappointing for some intervals, particularly in Units II and III, where values of $1 \%-2 \%$ were typical. In Unit IV of Hole $865 \mathrm{~A}$, recovery improved in basalts and clayey limestones and ranged from $10 \%$ to $100 \%$ in the deepest $100 \mathrm{~m}$ of the hole.

Despite the overall low core recovery, it was possible to reconstruct the lithologic sequence by comparing the cored material with a suite of geophysical, geochemical, and formation microscanner logs. The logs, compared with the measurements of sonic velocity and density on cored specimens, allowed a satisfactory correlation to be made between the reflectors seen on seismic profiles at the site and the observed sequence of strata drilled at the site. 
Leg 143

Preliminary Report

Page 14

Pelagic Cap Biostratigraphy

Biostratigraphic studies of the pelagic cap show the Paleogene section to be relatively complete, spanning nannofossil zones NP4-NP21 and foraminiferal zones P2-P17 (early Paleocene to early

Oligocene). This section is rare, not only because it contains sediments from an epoch (the Paleocene) that is rarely cored in Pacific pelagic sediments, but also because the guyot was near the equator, and its summit had a paleodepth of only about $1000 \mathrm{~m}$. What is more, the section appears to contain the Paleocene/Eocene boundary, a transition of considerable interest to paleoceanographers studying the shift of climate from warm in the Cretaceous to cold in the late Tertiary.

\section{Geochemistry}

Organic geochemistry measurements showed, as expected, that the percentage of $\mathrm{CaCO}_{3}$ in the cored material from Site 865 is generally high, typically greater than $95 \%$. A small percentage of lower values (as low as $27 \% \mathrm{CaCO}_{3}$ ) was found in clay-rich intervals in Unit IV. Despite the abundance of plant remains in the lowest sedimentary unit, total organic-carbon values were typically very low to low (less than $0.5 \%$ ). Moderate to high percentages (as much as $35.6 \%$ ) were found in Unit IV in small, organic-rich beds. Analyses of inorganic compounds in interstitial waters showed values consistent with seawater throughout all holes at the site. This suggests that both the pelagic cap and the limestones have a high permeability and are essentially open to seawater circulation. With the exception of samples from the very bottom of the hole, sulfate concentrations stay relatively constant and imply that sulfate reduction is not occurring quickly enough to deplete sulfate concentrations. A slight decrease in sulfate deep in Hole 865A suggests a small amount of reduction.

\section{Density and Seismic Velocity}

Physical properties show a discontinuity from the pelagic cap to limestone: porosities drop from $>60 \%$ to about $10 \%-20 \%$, and bulk densities jump from $1.6-1.7 \mathrm{~g} / \mathrm{cm}^{3}$ to $2.3-2.7 \mathrm{~g} / \mathrm{cm}^{3}$ (Fig. 4). Furthermore, seismic velocities are high in the limestones, with values $>4 \mathrm{~km} / \mathrm{s}$ from $140-400$ mbsf and decreasing to typically $2.0-3.5 \mathrm{~km} / \mathrm{s}$ below $500 \mathrm{mbsf}$. Downhole physical logs gave similar trends in bulk density, but show that the shipboard velocity readings are biased to the high 
Leg 143

Preliminary Report

Page 15

side by the selective recovery of the harder layers. In the limestone between 140 and 350 mbsf, the sonic log displays large variations in velocity, from about $2.0 \mathrm{~km} / \mathrm{s}$ to $4.5 \mathrm{~km} / \mathrm{s}$, apparently resulting from alternating hard and soft layers. Velocities below $350 \mathrm{mbsf}$ are more consistent, but average from about $2.9 \mathrm{~km} / \mathrm{s}$ to $3.5 \mathrm{~km} / \mathrm{s}$ with short excursions to higher values. Overall, both the sonic log and physical properties measurements demonstrate that the velocities used to calculate depths to seismic reflectors during pre-cruise planning, based mainly on plateau carbonate sediments, are significantly too low.

\section{Downhole Logs}

In addition to the FMS logs, mentioned above, downhole logs yielded valuable information about the structure and composition of the shallow-water limestones. The gamma-ray log showed significantly higher counts in the upper $60 \mathrm{~m}$ of the shallow-water limestone. This is possibly a result of scavenging of uranium by the phosphorite. Resistivity logs give numerous shortwavelength variations that probably result from thin beds. Finally, the formation microscanner gave a unique view of the structure of the limestone section. In the lowermost portion of Hole $865 \mathrm{~A}$, it is possible to make a detailed correlation of beds in the cores and imaged beds in the borehole wall. Moreover, in many intervals, structures such as vugs are visible in the microscanner recording. Clearly, the low recovery in the cores has biased the limestone samples, but the microscanner data will allow these samples to be put into perspective by comparison with the borehole images.

Interpretation

Data from Site 865 paint a classic Darwinian picture of carbonate atoll evolution from early formation to final drowning. The deepest recovered sediments (Subunit IVD) contain abundant fossil oyster specimens and evidence of intense burrowing, suggesting a restricted, shallow lagoonal environment. Abundant plant remains imply a nearby shoreline and marshy conditions. The presence of pyrite with associated organic matter indicates bacterial sulfate reduction in anoxic sediments, but the water must have been well-enough oxygenated for shallow infaunal activity. Gypsum and early diagenetic dolomite occur in some layers and may be due to seasonally evaporative conditions. Basaltic dikes intruded these sediments, probably at shallow depths. This event may represent late-stage volcanics or a rejuvenation of volcanism. 
Leg 143

Preliminary Report

Page 16

Subunit IVC shows periods of more open-marine conditions. The land-derived organic matter wanes through this sequence and disappears at the top of this subunit. Dolomite was not observed in sediments above Subunit IVB, and the clay disappears by the top of Subunit IVA, implying that the shoreline gradually retreated. Episodic concentrations of clay seams in these subunits suggest cyclic variations in water depth, caused either by autocyclic processes such as sedimentary-lobe switching, by allocyclic mechanisms such as irregular subsidence of the seamount foundations, by eustatic sea-level fluctuations, or by combinations of all of these.

The facies of Unit III suggest a quiet-water lagoonal environment. The degree of faunal diversity is not high, but the occurrence of rudists and corals higher in the section indicates conditions evolving from more restricted (Subunit IIIB) to open marine (Subunit IIIA). Winnowed carbonate sands in this unit suggest sporadic storm activity, whereas scattered reddish stains attest to periods of subaerial exposure. Evidence for prolonged emergence occurs at the top of the shallow-water carbonates in Unit II. Although these limestones are genetically the same as those in Unit III, they display mineralization, dissolution, and infilling of cavities by fine, possibly eolian, sediments as well as by upper Cretaceous pelagic sediments. High gamma-ray log readings imply concentrations of uranium either from eolian deposits or from association with phosphorite. The high uranium values suggest that the thickness of the exposed layer is approximately $68 \mathrm{~m}$. Shipboard biostratigraphic data (primarily benthic and planktonic foraminifers) suggest that the reef evolved and died quickly; the entire 731-m drilled section of shallow-water limestones appears to have been deposited within the last half of the Albian Stage (about 105-97.5 Ma).

Following exposure near the end of the Albian, the carbonate reefs drowned. The oldest pelagic fossils, in the cracks and cavities, are between mid-Turonian and late Coniacian (approximately 90 $87.5 \mathrm{Ma}$ ) in age. Sometime during the 5-10-m.y. interval between uplift and installation of pelagic conditions over the guyot, the emergent carbonate cap subsided below sea level, but without reestablishment of reefs. Since the seamount was probably located in low southern latitudes during all this time (Winterer et al., submitted; Sager et al., submitted), unusual conditions are required, for example, a rapid and substantial rise in sea level such as the rise postulated for CenomanianTuronian boundary (Suess, 1906; Hancock and Kauffman, 1979; Schlanger, 1986). During the remainder of the Cretaceous, after the carbonate platform drowned, the environment was mainly 
Leg 143

Preliminary Report

Page 17

non-depositional, leaving only a thin veneer of sediments. It is not yet clear whether later Cretaceous sediments were simply not deposited, or whether they were removed by subaerial erosion.

During the Paleogene, the guyot rode the Pacific plate northward across the equator. As it passed beneath the equatorial high-productivity zone, it acquired a substantial pelagic cap, consisting mainly of late Paleocene and early to mid-Eocene nannofossil and foraminiferal ooze and sand. Currents swirling around the summit eroded some of the cap and produced winnowed foraminiferal sands. Neogene sedimentation was slow, producing only a thin frosting that appears to rest unconformably on top of the thick Paleogene pile.

\section{$\underline{\text { Site } 866}$}

Sites 866 and 867/868 (proposed sites Hue-A and Hue-B, respectively) were drilled on the north rim of Resolution Guyot in the western Mid-Pacific Mountains (Figs. 5, 6, and 7). Sites 866 and $867 / 868$ were conceived as part of a transect across a Mid-Pacific Mountains guyot. Together with Site 463, drilled on DSDP Leg 62 (Thiede, Vallier, et al., 1981) and located about $24 \mathrm{nmi}$ (44.4 km) away in the basin to the east, they form a transect from lagoon to perimeter reef to basin. Site 866 is located at $21^{\circ} 19.95^{\prime} \mathrm{N}, 174^{\circ} 18.84^{\prime} \mathrm{E}$, in $1346.1 \mathrm{~m}$ of water (mbsl) and was placed to penetrate lagoonal facies limestones just behind (approximately $1.5 \mathrm{~km}$ ) the perimeter mound, so to be able to correlate lagoonal sediment facies, ages, and horizons with those drilled at Site 865 on Allison Guyot. It was also to be a multiple-reentry site whose goal was penetration of the entire limestone cap and a significant section of the volcanic pedestal.

Originally, one hole to a depth of about $950 \mathrm{~m}$ was planned at Site 866, but two were actually drilled. The first, Hole 866A, was drilled with a rotary core barrel and reached a total depth of 1743.6 mbsf, bottoming in basalt. Its great depth is a result of basalt being far deeper than estimated and the fact that the limestones of the carbonate cap made a stable hole, allowing deep drilling. From it, $1620 \mathrm{~m}$ of mostly shallow-water limestone and $124 \mathrm{~m}$ of subaerial basalt were cored. Recovery in the limestone section of Hole $866 \mathrm{~A}$ was poor at the top (average $1.4 \%$ in the top $300 \mathrm{mbsf}$ ) but increased downhole (average $34 \%$ in the bottom $220 \mathrm{~m}$ of limestone). The second hole, 866B, was drilled in the upper part of the limestone platform using a diamond core bit rather than a regular rotary bit, where recovery was poor in the first hole. The pelagic ooze 
Leg 143

Preliminary Report

Page 18

section, missed in $866 \mathrm{~A}$, was cored in $866 \mathrm{~B}$, showing that the mud line was incorrectly placed in the first hole and that the seafloor is actually $15.5 \mathrm{~m}$ shallower than assumed. Hole $866 \mathrm{~B}$ reached $117.4 \mathrm{mbsf}$, bottoming in limestone. Hole $866 \mathrm{~B}$, located about $30 \mathrm{~m}$ away from $866 \mathrm{~A}$, took only a short time to drill, $16.5 \mathrm{hr}$. Its average recovery was low, $4.3 \%$, but far better than that achieved in the same section of the previous hole.

Ages for the cores from Site 866 range from Barremian to Pliocene. Most of the section is Barremian to upper Albian shallow-water limestone, dated primarily from benthic foraminifers, resting upon basalt of uncertain age. Foraminiferal assemblages in the limestones indicate a Barremian age from 1620 to about 1200 mbsf, early to middle Aptian from 1200 to 271 mbsf, and late Albian from 271 to 0.9 mbsf. The break at $270 \mathrm{mbsf}$ appears to be a hiatus encompassing the late Aptian and early Albian, a period of perhaps 10-15 m.y. Another possible hiatus is suggested at about 1400 mbsf by an abrupt change in the paleodepth implied by the foraminifers. The basalt below the limestone is reversely polarized, implying that it formed during or prior to Chron M0. The shallow-water limestones are capped by a thin veneer of winnowed and reworked pelagic sediments containing both calcareous nannofossils and planktonic foraminifers ranging in age from Maastrichtian to Pliocene.

\section{Lithostratigraphy}

Using combined micro- and macro-fossil biostratigraphy, visual core descriptions, augmented with smear-slide and thin-section data, physical properties data, and downhole logs, eight principal stratigraphic units were recognized above volcanic basement (Fig. 8). Because core recovery was low in some intervals, the downhole logs were invaluable in constructing a stratigraphic framework and in correlating sedimentary layers with seismic horizons. In normal stratigraphic order (from bottom to top) the lithologic divisions are as follows:

Unit VIII (1620.0-1399.7 mbsf). Barremian dolomitized and undolomitized oolitic/oncoidal grainstone. The unit is divided into two subunits on the basis of dolomitization: the lowest $19 \mathrm{~m}$, overlying basalt, is almost undolomitized, whereas the upper $202 \mathrm{~m}$ is pervasively dolomitized and tan in color with lighter colored, unreplaced oncoids in parts. Common biogenic components are gastropods, bivalve fragments, echinoid spines, and green algae. 
Leg 143

Preliminary Report

Page 19

Coral fragments and bryozoans occur rarely. Dolomitization decreases upward and becomes patchy near the top of the unit.

Unit VII (1399.7-1203.4 mbsf). Barremian dolomitized oolitic/peloidal grainstone, oncoidal wackestone, and algal laminites, with clay/organic-rich layers. The main characteristic of this unit is the pervasive sucrosic dolomitization and the abundance of oncoids. It is split into four subunits by an interval of bright white dolomitized peloidal grainstone overlying a layer of coral peloidal grainstone in the middle part of the unit. Components include oncoids, benthic foraminifers, peloids, fragments of rudist and other bivalve shells, serpulid worm tubes, echinoids, corals, nerineiid gastropods, stromatoporoids, and dasycladacean algae. Intergranular and moldic porosity is common near the bottom of the unit.

Unit VI (1203.4-791.8 mbsf). Lower to middle Aptian cyclic packstone/wackestone with algal laminites, clay/organic-rich layers, and patchy dolomitization. The primary characteristic of Unit VI is the cyclic repetition of lithologies in meter-scale, shallowingupward sequences that imply fluctuations in relative sea level. Cycles typically begin with peloidal wackestone or packstone and grade upward into wackestone or mudstone. The tops of these sequences are commonly truncated and show small-scale desiccation cracks, implying emergence and erosion. Unit VI is subdivided into three parts based on the occurrence of a caprinid rudist biostrome in the middle.

Unit V (791.8-676.6 mbsf). Lower to middle Aptian oolitic grainstone. Unit V consists of $115 \mathrm{~m}$ of massive, well-sorted, oolitic grainstone which is cross-laminated in some spots. Though grainstone is predominant, there are short intervals with rudstone, where large fossils occur, and wackestone, where micrite is abundant. Other components are peloids, grapestones, intraclasts, rare oncoids, bivalve debris, corals, and gastropods. Locally, ooids and peloids are blackened by manganese oxides. The oolitic grainstones exhibit a high degree of overpacking and grain interpenetration.

Unit IV (676.6-434.5 mbsf). Lower to middle Aptian cyclic packstone/wackestone with scattered clay/organic-rich layers. Bioturbated peloidal packstone, wackestone, and grainstone with gastropods and foraminifers characterize Unit IV. Meter-scale submergenceemergence cycles occur, similar to those in Unit VI, with laminated wackestone and 
Leg 143

Preliminary Report

Page 20

packstone decreasing in frequency upward in the unit. Other components in these limestones are bivalve fragments, dasycladacean algae, and scattered lignite fragments. Smectite clay layers occur in the lower part of the unit and decrease upsection.

Unit III (434.5-19.6 mbsf, Hole 866A; 117.4-32.8 mbsf, Hole 866B). Middle Aptian to upper Albian wackestone and mudstone. This unit is predominantly wackestone with lesser amounts of mudstone, packstone, and grainstone. Common components are gastropods, bivalves, benthic foraminifers, echinoids, ostracodes, sponges, and dasycladacean algae. Rare components are corals, serpulid worm tubes, and bryozoans. Aragonitic fossils have been largely dissolved to create a moldic porosity. Calcrete layers decrease upward. Three subunits were distinguished, based on porosity and the occurrence of calcrete zones. A significant hiatus occurs between Subunits IIIB and IIIC (271 mbsf), with a gap between the Aptian and upper Albian.

Unit II (19.6-0.9 mbsf, Hole 866A; 32.8-23.5 mbsf, Hole 866B). Cretaceous manganiferous limestone. This poorly recovered unit is known from only a few small pebbles of manganese-encrusted limestone and from comparison with the mineralized limestone unit of Allison Guyot (Site 865). It represents the mineralized surface layer of the shallow-water limestones.

Unit I (0.9-0.0 mbsf, Hole 866A; 23.5-0.0 mbsf, Hole 866B). Maastrichtian to upper Pliocene foraminiferal nannofossil ooze. Unit $\mathrm{I}$ is the thin pelagic layer representing part of the post-drowning history of Resolution Guyot. It has been winnowed and reworked and contains iron-manganese micronodules.

\section{Biostratigraphy}

Most of the preliminary shipboard biostratigraphy is based on benthic foraminifers because planktonic foraminifers and calcareous nannofossils are absent from, and palynomorphs are rare in, the shallow-water limestones. The deepest sediments from Hole 866A (1619-1200 mbsf) contain a Barremian foraminiferal assemblage. A gradual shift to an early to middle Aptian assemblage occurs at about $1200 \mathrm{mbsf}$. Higher up in the sequence, at approximately $271 \mathrm{mbsf}$, an abrupt change to late Albian foraminifers marks a hiatus encompassing the late Aptian and early 
Leg 143

Preliminary Report

Page 21

\begin{abstract}
Albian (approximately 115-105 Ma). The thin layer of pelagic sediment atop the guyot has nannofossils and foraminifers of Maastrichtian to late Pliocene age, some of which are in reworked layers.
\end{abstract}

Physical Properties

Bulk density and sonic velocity measurements in the thick shallow-water limestone sequence show remarkable trends. The shallowest $420 \mathrm{~m}$ of recovered limestone exhibits relatively high seismic velocities and densities, with values of 4.4-6.5 km/s and 2.4-2.7 g/cm3, respectively. In the lower part of the limestone section, from 1619 to $1200 \mathrm{mbsf}$, high velocities and densities are also found, but there is a much larger range, approximately $2.1-6.8 \mathrm{~km} / \mathrm{s}$ and $2.15-2.75 \mathrm{~g} / \mathrm{cm} 3$, respectively (Fig. 8). The large scatter is evidently caused by alternating hard dolomite and softer limestone layers. In the middle of the section, from about 1200 to $420 \mathrm{mbsf}$, is a low-velocity/density zone with consistent velocities of $1.8-4.5 \mathrm{~km} / \mathrm{s}$ and densities of $2.1-2.4 \mathrm{~g} / \mathrm{cm} 3$. These trends are a significant departure from the common monotonic increase in seismic velocity and bulk density observed in most deep-sea sediments. Their cause is undoubtedly related to a complex diagenetic history.

\title{
Downhole Logs
}

As at Site 865 , the downhole logs from Hole $866 \mathrm{~A}$ provided a valuable framework for understanding the core material. Unfortunately, collapse of the basement section of the hole prevented significant penetration of the logging tools into the basalt section. In the limestones, sonic velocity and density logs show trends similar to those in the physical properties data, but the values were generally somewhat lower, indicating that the core material is a preferential sample of the more indurated material. Resistivity logs display excellent correlation with lithology. Highresistivity layers between 271 and 434 mbsf correspond to the dense, high-seismic-velocity mudstones and wackestones of lithologic Unit III. Likewise, high-resistivity layers in lithologic Units VII and VIII appear to correlate with pervasively dolomitized sediments. Geochemical and formation microscanner (FMS) logs were also recorded in Hole 866A. The geochemical logs require additional processing and interpretation, but appear to show small variations probably related to clay content. The FMS logs show variations in borehole-wall resistivity that suggest correlations to porosity and structure. Some of the variations appear cyclic. 
Leg 143

Preliminary Report

Page 22

Igneous Geology

Drilling in Hole 866A penetrated $124.8 \mathrm{~m}$ of basalt with $37 \%$ overall recovery (Fig. 9). The basalt/limestone contact is at $1620.0 \mathrm{mbsf}$. The basalt itself is subaerial and lightly to heavily altered. Red clay zones were cored in several intervals, indicating subaerial weathering and the development of lateritic soils. Poorly recovered rubbly zones imply that the basalt flows were of the clinkery aa type. Twelve flow units are recognized, separated on the basis of intervening lateritic or rubbly intervals. Above the basalt/limestone contact, volcaniclastic grains are generally small, not very abundant, and restricted to the $40 \mathrm{~m}$ above the basalt. This likely indicates that any exposed volcanic remnant was small and not close to the site. The chemistry of the basalts have intra-plate tholeiitic or mildly alkaline characteristics, and lack the strongly defined alkalic signature of the Allison Guyot sills.

Paleomagnetism

Magnetic measurements of the basalt section at the bottom of Hole 866A show that the basalts have reversed polarity. This shows that they are older than Chron M0 (118 Ma; Kent and Gradstein, 1985), since the basalt is overlain by Barremian-age sediments.

Geochemistry

Studies of inorganic compounds from interstitial waters in the pelagic cap and limestones show that these waters are mostly indistinguishable from normal seawater. On the other hand, sulfate and ammonium concentrations indicate a slight amount of reaction with buried organic matter. Carbonate content is generally high in the limestones, typically $97 \%-99 \%$, but decreases locally in clay layers, where values as low as $22 \%$ were measured. Low (less than $0.3 \%$ ) total organic carbon (TOC) values are typical of most of the limestones. In clay-rich layers and algal laminites, values were typically, but not always, higher.

Interpretation

Hole $866 \mathrm{~A}$ records virtually the entire history of carbonate platform formation, drowning, and diagenesis on Resolution Guyot. The story begins with the waning eruptive stages on the volcanic 
Leg 143

Preliminary Report

Page 23

pedestal. Its age is as yet unknown, but the reversed magnetic polarity implies that it formed during or prior to Chron M0 (approximately $118 \mathrm{Ma}$; Kent and Gradstein, 1985). The height of the pedestal was much smaller than expected. A comparison of extrapolated depth to basement at DSDP Site 463 with the depth of basement in Hole 866A implies that the volcanic edifice had a relief of only about $500 \mathrm{~m}$ above the basaltic plateau that underlies most of the western Mid-Pacific Mountains (Winterer and Metzler, 1984; Nemoto and Kroenke, 1985). An implication of this result is that a very large region of the western Mid-Pacific Mountains was at depths less than about $1 \mathrm{~km}$ from sea level in Barremian time. The volcanic underpinnings were quickly submerged and added little sediment to the limestones above.

The carbonate cap on Resolution was surprisingly thick, with approximately $1620 \mathrm{~m}$ of shallowwater limestone. This carbonate sequence ranges in age from Barremian to late Albian, with perhaps two hiatuses. One possible lacuna, at about 1400 mbsf in the Barremian, was recognized solely on the basis of an abrupt change in the paleodepth implied by foraminiferal assemblages. Consequently, it is of uncertain duration and significance. The other, at approximately $271 \mathrm{mbsf}$, shows a distinct change in foraminiferal assemblages from early to middle Aptian below to late Albian above. Evidently the carbonate platform formed in two stages: a thick sequence during rapid subsidence in the Barremian and early to middle Aptian, and a thinner cap during slower subsidence in the late Albian.

During the active stage of carbonate platform growth, the platform stayed at or near sea level. Generally, sediment facies show that most sediments were deposited in shallow, often restricted, lagoonal environments that gradually deepened and became more open marine with time. On the other hand, meter-scale facies cycles in much of the limestone section imply small-amplitude, shortterm fluctuations in relative sea level.

The cause of the gap in the carbonate platform history, a period of perhaps as great as 10-15 m.y., is uncertain. Two plausible end-member models are (1) Aptian subsidence and drowning followed by Albian uplift into shallow water and the reestablishment of growing reefs, and (2) Aptian reef growth followed by uplift to sea level, subaerial erosion, resubmergence, and the reestablishment of a late Albian reef. Further study of our data, perhaps augmented by geophysical data from other guyots, should clarify this ambiguity. 
Leg 143

Preliminary Report

Page 24

Final drowning of the platform occurred between late Albian and Maastrichtian time, when the first preserved pelagic sediments were deposited atop the shallow-water limestones. Sometime during this period, the platform was emergent and subjected to karsting, as suggested by sinkhole and other karstic features seen on $3.5-\mathrm{kHz}$ and seismic profiles over the guyot. This is also shown by freshwater dissolution and cave deposits in the uppermost part of the shallow-water limestones at Sites 866 and $867 / 868$. Subaerial exposure and the increased porosity it caused also led to phosphatization of these limestones.

Diagenesis was important in modifying the shallow-water carbonates. In general, three effects were noted: differential lithification, dolomitization, and karstification. Differential lithification created alternating layers of harder and softer limestone, so that density and porosity do not increase monotonically downward. A notable interval is the denser wackestone layers at the top of the Aptian section from about 431 to 271 mbsf. Dolomitization was locally pervasive but patchy. Although deeper limestone layers show the most dolomitization, some interbedded layers and the overlying layers were unaffected or only lightly dolomitized. The timing of the dolomitization is uncertain, but indications are that it occurred soon after burial. Post-Albian subaerial exposure and the creation of a lens of fresh water within the uppermost limestone layers caused widespread dissolution and the formation of cavities and cavity deposits in the vadose zone. Many cavities were later filled by fine-grained sediments and permeated with phosphate and iron-manganese oxyhydroxides.

Drilling at Site 866 changed the way we view Cretaceous, carbonate-capped guyots. For years geophysical ships crossed these features and brought back profiles that were fitted to the classic picture of modern atolls. A prominent, deep seismic reflector was commonly seen and assumed to be the volcanic basement upon which a fringing reef grew. This volcanic pedestal was generally thought to make up the preponderance of the guyot, typically with several kilometers of volcano capped with less than a kilometer of limestone. Furthermore, prominent mounds around the guyot perimeter, and scattered seismic energy at the guyot edges, were presumed to show a drowned fringing reef. Layered seismic horizons in the interior were interpreted as lagoonal limestones with relatively low seismic velocities and densities, both of which should nominally increase with depth. 
Leg 143

Preliminary Report

Page 25

Hole 866A showed that, in the Mid-Pacific Mountains at least, the original volcano had much less relief than the final guyot. What is more, estimates of the thickness of the carbonate cap were off by a factor of 2 because the "basement" reflector was not associated with the top of the volcanic pedestal, and the acoustic wave velocities of the limestones were greatly underestimated. Both errors are a result of the diagenesis of the limestone cap. In addition to these misinterpretations, the modern atoll model may also be inadequate. Despite drilling nearly $2 \mathrm{~km}$ of carbonate material at Site 866 , a location only about $1.5 \mathrm{~km}$ from the edge of the guyot, little reef-derived material was recovered. Instead, open-water platform components, such as oolites, were common.

\section{Site $867 / 868$}

Site 867 , located at $21^{\circ} 20.96^{\prime} \mathrm{N}, 174^{\circ} 18.56^{\prime} \mathrm{E}$, in a water depth of $1352.2 \mathrm{mbsl}$, is on the perimeter mound nearest Site 866 (Figs. 5, 6). It was envisaged as a shallow hole to penetrate only the karsted upper $300 \mathrm{~m}$ of the atoll perimeter reef. Site 868 , located at $21^{\circ} 21.17^{\prime} \mathrm{N}, 174^{\circ} 18.56^{\prime} \mathrm{E}$, in a water depth of $1384.9 \mathrm{mbsl}$, is on a terrace, approximately $33 \mathrm{~m}$ deeper and $400 \mathrm{~m}$ outside the perimeter mound (Fig. 6). Because of the shallow water depth, a separate beacon had to be used for Site 868; hence, it is catalogued as a different site than 867. Because of their proximity in space and in scientific theme, the sites are joined for purposes of our reports.

Proposed site Hue-B (Site 867) was to be a single, shallow-penetration (approximately $300 \mathrm{~m}$ ) hole drilled into the perimeter mound surrounding the summit of Resolution Guyot. It had been assumed that this mound was a Cretaceous reef that had drowned and perhaps even been emergent owing to relative sea-level fall. A second hole (Site 868) was drilled because results from previous Leg 143 sites suggested that there is a significant gap in time between the oldest platform carbonates and the first pelagic sediments to accumulate atop the platform. It was thought that the lower terrace might be a sea-level lowstand reef complex, whose drilling might help to fill the gap.

Two holes were drilled at Site 867; both were spudded-in with no guide base on hard limestone having virtually no sediment cover. Hole $867 \mathrm{~A}$ consisted of a single core drilled with a diamond bit. The small-diameter bottom-hole assembly sheared off at the outer core barrel, so the hole was terminated. Hole 867B was drilled to a depth of $76.8 \mathrm{mbsf}$ with $29.2 \%$ average recovery. The average recovery would have been higher, but the section contained a 9-m cavity which, of course, yielded no core. Hole 868A, the only hole drilled at that site, penetrated $20.3 \mathrm{mbsf}$, recovering 
Leg 143

Preliminary Report

Page 26

$46.3 \%$ of the section. Slow drilling rates and time constraints did not allow accomplishment of $300 \mathrm{~m}$ of penetration.

\section{Lithostratigraphy}

Cores from Sites $867 / 868$ consist of shallow-water limestone with a thin veneer of pelagic limestone (Fig. 10). Based primarily on benthic foraminifers, the shallow-water limestone is late Albian in age, whereas planktonic foraminifers and nannofossils indicate an Eocene age for the overlying pelagics. Two lithologic units were recognized at Site 867, and core from Site 868 is equivalent to the second, stratigraphically lower, unit from Site 867. In stratigraphic order these units are:

Unit II (10.0-0.0 mbsf, Hole 867A; 76.9-0.29 mbsf, Hole 867B; 20.3-0.0 mbsf, Hole 868A). Albian bivalve/gastropod/echinoid wackestone to packstone, grainstone to floatstone beach deposits, and oolitic grainstone. A variable amount of skeletal material is present, including rudists, sponges, and corals. These limestones have two outstanding characteristics. First, they display meter-scale, fining-upward, transgressive-regressive sequences modulating an overall shift from restricted lagoon to open-marine shoreface going upsection. Second, virtually the entire sequence, down to at least $62 \mathrm{mbsf}$, contains centimeter-scale dissolution cavities, many of which contain speleothems and imply dissolution in the lower vadose zone. Some cavities may be much larger; one section of about 9-m length gave no resistance to the drill string and is thought to be a cavity. Unit II is subdivided into three subunits, the uppermost of which is distinguished by multiple generations of internal sediment (mudstone) of different colors and compositions, the most prominent of which is dark brown, fine-grained phosphatic material. This subunit also gives high readings on the gamma-ray logs, as did the upper limestone layers of Allison Guyot, probably owing to the pervasive phosphatization. The second subunit is essentially the same, except for the absence of cavity infilling and pervasive phosphatization. A notable feature of this subunit is coarse-grained intervals of floatstone to rudstone interbedded with finer grained wackestone, packstone, and grainstone. The coarser grained sediments are composed mainly of caprinid rudist and gastropod shell fragments, intraclasts, and peloids. The entire section drilled at Hole $868 \mathrm{~A}$ is distinguished as the third subunit because it is characterized by intervals of boundstone consisting of calcareous sponge fragments. 
Leg 143

Preliminary Report

Page 27

The boundstone is interbedded with floatstone and grainstone containing rudists, gastropods, sponge fragments, possible oyster fragments, and oncoidally coated particles. This subunit also contains a layer of red-stained limestone that suggests emergence.

Unit I (0.29-0.0 mbsf, Hole 867B). Eocene foraminiferal nannofossil limestone, heavily replaced and impregnated with phosphate and manganese dendrites. This unit represents the first permanent pelagic sedimentation at the site.

Interpretation

The facies evolution of Sites 867/868 implies an overall opening of the environment, from restricted lagoon to open-marine foreshore. This trend is modulated by meter-scale transgressiveregressive cycles. Many of the cycles begin with storm deposits, typically with an erosive base, and grade to lagoon, tidal flat, or beach. The most obvious diagenetic process is dissolution, probably due to subaerial exposure and karsting. Cavities formed by this process in the upper part of the section were partially or wholly filled by a later generation of fine-grained sediment. The final stage of carbonate platform evolution was the deposition of a thin cover of pelagic sediments.

The results from Sites 867/868 have two important implications. First, the dissolved cavities with speleothems are strong evidence of emergence and confirm inferences of karsting based on seismic reflection profiles and multibeam echo-sounder data over Resolution and other Pacific guyots. Furthermore, the depth of the dissolution, 62 mbsf at Site 867, combined with the nearly $100 \mathrm{~m}$ of limestone relief above the site in the guyot center, together imply a relative sea-level fall of at least $160 \mathrm{~m}$. Second, the cores from Sites $867 / 868$ contain much less reefal material than expected. The perimeter mound, once thought to be a reef, may be only a perimeter island chain instead. Furthermore, the volume contribution from reefs to the building of the carbonate platform atop the guyot may be smaller than previously thought.

\section{$\underline{\text { Site } 869}$}

Site 869 (proposed site Syl-3) is situated $45 \mathrm{nmi}(83 \mathrm{~km})$ southwest of the atoll-guyot pair Pikinni (formerly "Bikini") Atoll and Wodejebato (formerly "Sylvania") Guyot at $11^{\circ} 00.09 ' \mathrm{~N}$, $164^{\circ} 45.02^{\prime} \mathrm{E}$, in a water depth of $4826.7 \mathrm{mbsl}$ (Fig. 11). Dirilling at this location was planned to 


\section{Leg 143}

Preliminary Report

Page 28

provide a basinal reference section for comparison to Leg 144 drill holes on the summit of Wodejebato and prior drilling on Pikinni. Site-survey data suggested that there is a thick, layered succession of sediments at the site, consisting mainly of turbidites (Fig. 12). Volcanic basement is not obvious in the site-survey seismic lines (Fig. 12), so drilling was not expected to encounter basement basalt. Approximately $850 \mathrm{~m}$ of penetration was planned, and the expectation was to bottom in Cretaceous volcaniclastics produced by constructional volcanism on either or both Wodejebato and Pikinni.

Two holes were drilled at Site 869, an APC/XCB hole, 869A, and an RCB hole, 869B, the latter located about $30 \mathrm{~m}$ east of the former. The operational plan was to use the $\mathrm{APC} / \mathrm{XCB}$ combination to obtain relatively undisturbed cores from the upper 300-400 $\mathrm{m}$ of the sedimentary column. In analogy to Site 462 , hard chert layers were expected to frustrate drilling at about $300-400 \mathrm{mbsf}$, and a round-trip was planned to change to an $\mathrm{RCB}$ bit and begin a second hole. Chert and porcellanite were encountered at much shallower depths than expected, and Hole 869A was terminated at a depth of only $166.5 \mathrm{mbsf}$. Hole $869 \mathrm{~B}$ was washed to $140.0 \mathrm{mbsf}$ and cored continuously to a total depth of $796.2 \mathrm{mbsf}$.

Core recovery in Hole $869 \mathrm{~A}$, drilled with the $\mathrm{APC} / \mathrm{XCB}$ combination, was good, the average being over $100 \%$ for the APC cores and $77.6 \%$ overall. In Hole 869B, recovery was variable. In cherty sections, recovery was generally low $(<5 \%)$, obtaining only a few pebbles of chert in some cores. In contrast, recovery in Cretaceous volcaniclastic turbidites was typically in excess of $60 \%$. In general, recovery increased downhole in Hole 869B, averaging about $20 \%$ from 200 to 500 mbsf and increasing to $70 \%$ at the bottom of the hole.

\section{Lithology}

Using combined micro- and macrofossil biostratigraphy, visual core descriptions augmented with smear-slide and thin-section data, physical properties data, and downhole logs, three principal stratigraphic units were recognized (Fig. 13). In stratigraphic order, from bottom to top, the lithologic divisions are as follows:

Unit III (796.2-217.2 mbsf). Middle/upper Cenomanian to upper Campanian/lower Maastrichtian volcaniclastics interlayered with nannofossil and radiolarian claystone. 
Leg 143

Preliminary Report

Page 29

This unit is characterized by numerous gray to green volcaniclastic sandstones and breccias intercalated with lighter colored claystones. Seven lithologic subunits are recognized on the basis of changes in the mix, grain sizes, or depositional style of the dominant components. Subunits IIIF (780.7-653.3 mbsf), IIIE (653.3-536.1 mbsf), IIIC (487.8-458.8 mbsf), and IIIA (381.5-217.2 mbsf) consist mostly of volcaniclastic sandstone interbedded with claystone. These similar subunits are punctuated by Subunits IIIG (796.2-780.7 mbsf), a volcanic siltstone with calcareous claystone, IIID (536.1-487.8 mbsf), a volcanic breccia, and IIIB (458.8-381.5 mbsf), consisting mainly of radiolarian-rich claystone. The volcaniclastic layers consist mainly of sand-size grains, deposited by turbidites. Basaltic clasts are common, in places forming breccias, but also occurring within a fine-grained matrix and implying transportation by grain-flow. Most clasts are subangular to subrounded, suggesting a moderate transport distance. The largest clasts are up to $80 \mathrm{~mm}$ in diameter, and most have been affected by light to moderate alteration. The volcaniclastic layers contain clinopyroxene, palagonite, feldspar, zeolite, epidote, and chlorite grains, attesting to a basaltic parentage. Zeolites are a common cement.

Claystone occurs abundantly in some parts of the section (e.g., Subunit IIIB), but rarely in others (e.g., Subunit IIIF). The claystone is locally calcareous, siliceous, and/or zeolitic. Radiolarian and nannofossil concentration is variable; in some layers these fossils are dispersed through the matrix, and in others they are concentrated in millimeter-scale beds. Shallow-water biogenic fragments occur only rarely but are most abundant in Subunits IIIA, IIIB, and IIIC. Bivalve shell, gastropod, echinoid, red-algal, and recrystallized skeletal fragments were found, as were orbitolinid foraminifers, micritic ooids, peloids, and glauconite. Coalified woody fragments were found in Core 143-869B-51R, at a depth of 618 mbsf.

Unit II (217.2-88.2 mbsf, Hole 869A; 217.2-140.0 mbsf, Hole 869B). Late Campanian/late Maastrichtian to upper Eocene radiolarian-nannofossil ooze and nannofossil-radiolarian ooze with porcellanites and chert. Recovery of this unit was low (about $40 \%$ ), but it appears to consist of alternating layers of hard chert and soft ooze. Porcellanites and cherts make up a significant fraction of the recovered lithology in the bottom of the unit and decrease in abundance upward. Layers of nannofossil limestone and chalk occur in places through the section. 
Leg 143

Preliminary Report

Page 30

Unit I (88.2-0.0 mbsf). Upper Eocene to lower Miocene clayey nannofossil ooze and radiolarian-nannofossil ooze. Major components of the oozes are nannofossils, radiolarians, sponge spicules, and clay. Color and compositional changes show cycles, on various scales, as the mix of principal components varies. The unit is divided into two subunits by a stratigraphic gap between upper Oligocene and lower Miocene.

\section{Biostratigraphy}

Nannofossils provided most of the datable biomarkers for constructing an age framework for Holes 869A and 869B. Abundance increases uphole, from few to absent in the volcaniclastic turbidites to abundant in the ooze section. Preservation is generally moderate to poor. Foraminifers are few to rare and also generally increase in abundance uphole; however, they are missing from all but the Oligocene section of Hole 869A. Their preservation is typically poor. Radiolarians are common, but there was no specialist on board to study them, so they did not contribute to the shipboard biostratigraphy.

The lower portion of Hole $869 \mathrm{~B}$ consists of about $320 \mathrm{~m}$ of intercalated turbidites and claystones of late Cenomanian age. Extremely rapid sedimentation rates are indicated, as virtually the entire Cenomanian sequence is within the uppermost Cenomanian biozone CC10. Above the Cenomanian strata, up to 207 mbsf, are more volcaniclastic turbidites and intercalated claystones ranging in age from Turonian to late Campanian/early Maastrichtian. This interval contains an expanded Campanian section, from approximately 400 to $225 \mathrm{mbsf}$. Into the Cenozoic, there is a change in lithology to cherts and radiolarian-nannofossil oozes. The uppermost cored interval of Hole $869 \mathrm{~B}$ is late Paleocene to early Eocene in age. Hole $869 \mathrm{~A}$ yielded entirely Cenozoic-age sediments, ranging from middle Eocene to early Miocene. The stratigraphic progression at Site 869 is punctuated by five recognized hiatuses: the upper Coniacian to lower Santonian, upper Maastrichtian to lower Paleocene, part of the upper Paleocene, a section including the Oligocene/Miocene boundary, and post-early Miocene sediments missing at the seafloor. Of these, the most prominent is the upper Maastrichtian-lower Paleocene hiatus, which spans up to 10 m.y. and includes the Cretaceous/Tertiary boundary. 
Leg 143

Preliminary Report

Page 31

Paleomagnetism

Paleomagnetic measurements of the sediments cored in Hole 869A were ruined by pervasive rust contamination of the APC/XCB cores. Measurements of discrete samples and archive-half samples from the Cretaceous section of Hole 869B showed normal polarity down to Core 143-869B-21R, reversed polarity from Cores $143-869 \mathrm{~B}-21 \mathrm{R}$ to $-26 \mathrm{R}$, and normal polarity below. This reversed zone is interpreted as Chron 33R, the first reversed polarity epoch after the Cretaceous Quiet Period (Cretaceous Normal Superchron, K-N). Paleolatitudes from Hole 869B samples are in low southern latitudes, $10^{\circ}-20^{\circ}$ south.

\section{Sedimentation Rates}

Because shipboard interpretations of magnetic stratigraphy were hampered by rust contamination in Hole 869A and by the few reversals in the Cretaceous sections drilled in Hole 869B, calculated sedimentation rates were based solely on biostratigraphy. Sediments accumulated in the Cenomanian section, from the bottom of the hole up to about $470 \mathrm{mbsf}$, at the rapid rate of $60 \mathrm{~m} / \mathrm{m}$.y or greater. In the Cretaceous section above, up to about $207 \mathrm{mbsf}$, the overall rate was about $15 \mathrm{~m} / \mathrm{m}$.y. A hiatus of approximately 10 m.y. duration separates the Cenozoic and Mesozoic parts of the sedimentation curve, and the average sedimentation rate in the Cenozoic was about $4.5 \mathrm{~m} / \mathrm{m} . \mathrm{y}$.

\section{Geochemistry}

Marked downhole concentration trends of cations reflect diagenetic changes within the volcanogenic sediments: $\mathrm{Ca}$ and $\mathrm{Sr}$ are released by feldspars, whereas $\mathrm{Mg}, \mathrm{K}, \mathrm{Na}$, and $\mathrm{Rb}$ are decreased by incorporation into alteration products. High silica concentrations in Hole 869A result from high biogenic silica concentrations. $\mathrm{CaCO}_{3}$ percentage varied with the mix of sedimentary components, from highs of greater than $97 \%$ to lows of less than $1 \%$ in some cherts, claystones, and volcaniclastic layers. In Hole $869 \mathrm{~A}, \mathrm{CaCO}_{3}$ increases with depth from about $50 \%$ through lithologic Subunit IA, is nearly constant above $90 \%$ through Subunit IB, and decreases with depth to about $20 \%$ at the bottom of Unit II. In Hole $869 \mathrm{~B}, \mathrm{CaCO}_{3}$ concentration is highly variable but generally low, typically less than $10 \%$. Peaks of $\mathrm{CaCO}_{3}$ content, commonly greater than $20 \%$, 
Leg 143

Preliminary Report

Page 32

occur within chalk and claystone layers intercalated between volcanogenic layers. Total organic carbon in both Holes 869A and 869B is low to very low, with the greatest values less than $0.8 \%$.

Physical Properties

Overall, physical property trends at Site 869 are what would be expected for basinal sediments: bulk density and sonic velocity increase slightly downhole (from about 1.5 to $2.1 \mathrm{~g} / \mathrm{cm}^{3}$ and 1.5 to $2.6 \mathrm{~km} / \mathrm{s}$ ), whereas porosity and water content decrease (from $70 \%$ to $35 \%$ and $60 \%$ to $20 \%$, respectively). Superimposed upon these trends are fluctuations caused by variations in the composition and layering of turbidites and volcanic breccias. The radiolarian and nannofossil-rich oozes of Hole 869A show remarkable variations in bulk density, apparently owing to variable carbonate content; however, the sonic velocity remains nearly constant throughout except for intercalated chert layers. Physical properties are more variable in cores from Hole 869B because they have highly variable compositions, consisting mostly of volcaniclastic turbidites and breccias interlayered with marly, nannofossil and radiolarian-rich claystone. Sonic velocities as high as 4 to $5 \mathrm{~km} / \mathrm{s}$ and anisotropies over $15 \%$ are measured from samples taken out of cores from the lower $300 \mathrm{~m}$ of Hole 869B.

\section{Downhole Logs}

Four logging runs were done in Hole 869B. The first, with the quad tool (gamma-ray, sonicvelocity, neutron-porosity, resistivity, and temperature), extended from $777 \mathrm{mbsf}$ to the pipe at $112 \mathrm{mbsf}$. For the second and third, the Formation Microscanner (FMS) and Japanese magnetometer, hole-penetration problems dictated lowering the pipe to $235 \mathrm{mbsf}$, below the Cenozoic chert layers. The FMS and magnetometer were then lowered to 775 and $724 \mathrm{mbsf}$, respectively, and run up to the base of the pipe. The final run, with the geochemical tool string, was abbreviated because of time constraints, but it recorded data from 560 to $360 \mathrm{mbsf}$.

The quad tool produced good data showing excellent correlation of resistivity, density, and gammaray reflectance with lithology and the seismic reflection record (Fig. 13). In particular, several prominent volcaniclastic turbidite-breccia layers show up as upward-fining sequences. The Japanese magnetometer showed prominent anomalies that also correspond to some of these units. 
Leg 143

Preliminary Report

Page 33

Interpretation of the FMS and geochemical tool data awaits processing, but the preliminary FMS data in particular promise a good record of the structure of the borehole wall.

\section{Seismic Stratigraphy}

Combining downhole sonic velocity logs with lithologic and physical properties data, changes in acoustic impedance can be determined that correlate with most seismic reflectors. In general, the Cenozoic layers show hummocky forms that suggest turbidite channels, and strong reflectors appear to be caused by silicified layers of porcellanite or chert. The upper Mesozoic layers appear more flat-lying, and reflectors come in packets that are probably caused by volcaniclastic turbidites. The strongest and most continuous reflector, at a two-way traveltime of $0.44 \mathrm{~s}$, appears to correlate with the sharp base of a unit of coarse volcanic breccia and turbidites cored from 509 to $543 \mathrm{mbsf}$. Reflectors beneath this depth become increasingly intermittent and show more relief, corresponding to massive volcaniclastic turbidites and breccias of the rapidly deposited Cenomanian section. Drilling at Site 869 terminated at a depth of $796.2 \mathrm{mbsf}$, short of at least two additional reflectors at two-way traveltimes of 0.89 and $1.05 \mathrm{~s}$, with extrapolated depths of 1000 and $1230 \mathrm{mbsf}$. There is no indication on the seismic records of true basaltic basement, suggesting that the sedimentary section at Site 869 may be quite thick.

\section{Interpretation}

Site 869 shows rapid deposition of Cretaceous sediments, mainly volcaniclastic sandstones, siltstones, and breccias, against a background of pelagic sedimentation. A thick section of Cenomanian volcaniclastics, over $300 \mathrm{~m}$ in thickness, was cored from the bottom of Hole 869B, and no bottom was reached. It suggests that volcanism on nearby seamounts (probably Wodejebato or Pikinni) contributed a large volume of material to the adjacent basin. Interestingly, dredges from nearby Wodejebato Guyot yielded Albian shallow-water carbonates, implying that the underlying seamount formed during or prior to the Albian, a chapter of the depositional history not sampled at Site 869 .

The Cenomanian section is essentially devoid of shallow-water material, suggesting that the massive influx of volcaniclastics overwhelmed any input of such material. Conversely, higher in the section, shallow-water debris becomes more important, although it is never abundant. 
Leg 143

Preliminary Report

Page 34

Volcaniclastic material waxed and waned through the rest of the Cretaceous, with a significant influx during the early to late Campanian, perhaps signalling another phase of volcanism on a nearby seamount. Grain sizes and distributions vary greatly in the volcaniclastic layers. There are large-grained breccias (with clasts up to $80 \mathrm{~mm}$ in diameter), sand- and silt-sized turbidites, and grain flows with large clasts surrounded by fine-grained matrix. These structures imply energetic, probably channelized, transport by turbidites, grain flows, and mass flows from relatively nearby sources.

At the end of the Cretaceous, the volcaniclastic input waned and the sediments changed to nannofossil and radiolarian-rich oozes, some of which were silicified into chert and porcellanite layers. Sedimentation was episodic, with numerous hiatuses and low sedimentation rates in the Cenozoic. Many of the Cenozoic sedimentary layers are turbidites, probably shed from the nearby Wodejebato-Pikinni edifice. Interestingly, sediments younger than early Miocene are not found at Site 869 , and the seafloor morphology suggests they have been removed, probably by bottom currents.

$\underline{\text { Site } 870}$

Site 870 (proposed site Ane-1) was drilled at $11^{\circ} 20.83^{\prime} \mathrm{N}, 162^{\circ} 15.78^{\prime} \mathrm{E}$, in $38.6 \mathrm{~m}$ of water in the lagoon of Anewetak Atoll in the Marshall Islands (also known as Enewetak or Eniwetok). The main purpose of this site was a test of the shallow-water station-keeping and drilling capabilities of the JOIDES Resolution. Anewetak has been extensively surveyed and drilled by the U.S.

Geological Survey, and its location close to Site 869 made it a convenient location for the shallowwater test. The location for drilling was to be in a water depth of $<40 \mathrm{~m}$ near the southern end of the lagoon (Fig. 14), near the cross point of USGS lines 405, 407, and 409. The actual position was based on finding the clearest spot away from shallow coral knolls, which could pose a hazard to the ship. Because this was an engineering test, scientific goals were considered secondary; nevertheless, it was hoped that core could be retrieved from the upper $100 \mathrm{~m}$ of this modern atoll and provide a contrast and comparison with Cretaceous shallow-water carbonates drilled at other Leg 143 sites.

Station-keeping and positioning tests provided valuable insights to the handling of the drill ship in shallow water with variable currents. The taut-wire system was able to hold the ship on position 
for a period of hours, although an abrupt change in current speed and direction caused an unacceptable excursion at one point. Changing the ship heading by small angles caused insignificant pipe-angle deflections, but heading changes of $45^{\circ}$ gave rise to $5^{\circ}-7^{\circ}$ deflections. A modified deep-water beacon was tried as a backup position reference, but it saturated the hydrophones. Additionally, the taut-wire tugger-winch was damaged by stress on the taut-wire arm at high wire angles. Overall, the positioning tests were successful and indicated areas where improvements can be made.

Drilling at Site 870 produced little core material. Hole conditions were unstable, probably owing to loose sand, and eventually caused drilling to be terminated. In all, $0.6 \mathrm{~m}$ of material was recovered from $31.5 \mathrm{~m}$ of coring. Hole 870A was cored with an APC/XCB BHA to a sub-bottom depth of $0.2 \mathrm{~m}$. Core $143-870 \mathrm{~A}-1 \mathrm{H}$ had $0.19 \mathrm{~m}$ recovery and consists of unconsolidated bioclastic sand and gravel with foraminifers, gastropods, bivalves, bryozoans, and encrusting red and green algae. Hole 870B was cored with an APC/XCB BHA to a sub-bottom depth of $31.3 \mathrm{~m}$. Cores 143-870B-1X to $-3 \mathrm{X}$ had $<1 \%$ recovery, consisting of more indurated bioclastic rudstone and grainstone and coral debris. The age of the sediments is Holocene. 
Leg 143

Preliminary Report

Page 36

\section{REFERENCES}

Darwin, C., 1842. The Structure and Distribution of Coral Reefs: London (Smith, Elder).

Hancock, J.M. and Kauffman, EG., 1979. The great transgressions of the Late Cretaceous.

J. Geol. Soc. London 136:175-186.

Hess, H.H., 1946. Drowned ancient islands of the Pacific basin. Am. Jour. Sci. 244:772-791.

Kent, D.V., and Gradstein, F., 1985. A Cretaceous and Jurassic geochronology.

Geol. Soc. Am. Bull. 96:1419-1427.

Ladd, H.S., Newman, W.A., and Sohl, N.F., 1974. Darwin Guyot, the Pacific's oldest atoll. Proc. 2nd Int. Coral Reef Symp. 2:513-522.

Larson, R.L., 1991. The latest pulse of the Earth: evidence for a mid-Cretaceous super plume. Geology 19:547-550.

Matthews, J.L., Heezen, B.C., Catalano, R., Coogan, A.; Tharp, M., Natland, J., and Rawson, M., 1974. Cretaceous drowning of reefs on Mid-Pacific and Japanese guyots. Science 184:462-463.

McNutt, M.K., Winterer, E.L., Sager, W.W., Natland, J.H., and Ito, G., 1990. The Darwin Rise: a Cretaceous superswell? Geophys. Res. Lett. 17:1101-1104.

Menard, H.W., 1964. Marine Geology of the Pacific: New York (McGraw-Hill), 271 pp.

Menard, H.W., 1984a. Darwin reprise. Jour. Geophys Res. 89:9960-9968.

Menard, H.W., 1984b. Origin of Guyots: the Beagle to SeaBeam. Jour. Geophys. Res. 89:1111711123.

Nemoto, K., and Kroenke, L.W., 1985. Sio Guyot: a complex volcanic edifice in the western MidPacific Mountains. Geo-Mar. Lett. 5:83-89.

Sager, W.W., Duncan, R.A., and Handschumacher, D.W., submitted. Paleomagnetism of Japanese and Wake seamounts, western Pacific. In Pringle, M., Sager, W.W., Sliter, W.V., and Stein, S. (Eds.), The Mesozoic Pacific: Washington (Am. Geophys. Union).

Schlanger, S.O., Jenkyns, H.C., and Premoli-Silve, I., 1981. Volcanism and vertical tectonics in the Pacific Basin related to global Cretaceous transgressions. Earth Planet. Sci. Lett. 52:435449.

Schlanger, S.O., 1986. High frequency sea-level fluctuations in Cretaceous time: an emerging geophysical problem. In Hsü, K.J. (Ed.), Mesozoic and Cenozoic Oceans: Washington (Am. Geophys. Union); Boulder, Colorado (Geol. Soc. Am.), 61-74. 
Leg 143

Preliminary Report

Page 37

Suess, E., 1906. The Face of the Earth Vol. 2: Oxford (Clarendon Press), 759 pp.

Tarduno, J.A., Sliter, W.V., Kroenke, L., Leckie, E.L., Mayer, H., Mahoney, J.J., Musgrave, R., Storey, M., and Winterer, E.L., 1991. Rapid formation of Ontong Java Plateau by Aptian mantle plume volcanism. Science 254:399-403.

Thiede, J., Vallier, T.L., and Shipboard Scientific Party, 1981. Site 463: western Mid-Pacific Mountains. Init. Repts. DSDP 62: Washington (U.S. Govt. Printing Office), 33-156.

Wheeler, C.W., and Aharon, P., 1991. Mid-oceanic carbonate platforms as oceanic dipsticks: examples from the Pacific. Coral Reefs 10:101-106.

Winterer, E.L., Duncan, R.A., McNutt, M.K., Natland, J.H., Premoli-Silva, I., Sager, W.W., Sliter, W.V., van Waasbergen, R.J., and Wolfe, C.J., submitted. Cretaceous guyots in the northwest Pacific: an overview of their geology and geophysics. In Pringle, M., Sager, W.W., Sliter, W.V., and Stein, S. (Eds.), The Mesozoic Pacific: Washington (Am. Geophys. Union).

Winterer, E.L., and Metzler, C.V., 1984. Origin and subsidence of guyots in the Mid-Pacific Mountains. J. Geophys. Res. 89:9969-9979. 
Leg 143

Preliminary Report

Page 38

\section{FIGURES}

Figure 1. Map of western Pacific showing Leg 143 drill sites and ship's survey track between sites from Honolulu to Majuro. Stippled areas denote regions above $4000 \mathrm{~m}$ water depth. Larger islands are shown in black.

Figure 2. Bathymetric map of Allison Guyot summit, showing location of Site 865. Bathymetric contours (in hundreds of meters) are shown at 100-m intervals, with heavy contours at $400-\mathrm{m}$ intervals. Supplementary $50-\mathrm{m}$ contours on the guyot summit are shown by dashed lines. Bathymetric data were obtained with the SeaBeam multibeam echo-sounder during 1988 on Leg 10 of the Roundabout Expedition of the Thomas Washington of Scripps Institution of Oceanography.

Figure 3. Single-channel seismic profile over the summit of Allison Guyot, showing location of Site 865. Profile was collected during Leg 10 of the Roundabout Expedition of the Thomas Washington of Scripps Institution of Oceanography.

Figure 4. Summary of lithologic, biostratigraphic, physical properties, and logging data from Site 865. Measurements of P-wave velocity are discriminated for orientation: $\mathrm{Vpu}=$ unoriented; $\mathrm{Vpta}$ and $\mathrm{Vptb}=$ transverse (horizontal); $\mathrm{Vpl}=$ longitudinal (parallel to core). Age of pelagic sediments is from Hole 865B; other data are from Hole 865A.

Figure 5. Bathymetry of Resolution Guyot and geophysical ship tracks. Bathymetric contours (in hundreds of meters) are shown at 100 -m intervals where there is SeaBeam multibeam echosounder coverage. Contours include data acquired during pre- and post-drilling surveys aboard the JOIDES Resolution. Dashed lines show ship tracks. Site 463 (DSDP Leg 62; Thiede, Vallier, et al., 1981) is denoted by an open circle. Site survey data were acquired during 1988 on Leg 10 of the Roundabout Expedition of the Thomas Washington of Scripps Institution of Oceanography. Roundabout cruise dredges shown by filled squares.

Figure 6. 3.5-kHz echo-sounder profile over Sites 866,867 , and 868 taken on board the JOIDES Resolution during pre-drilling survey. 
Leg 143

Preliminary Report

Page 39

Figure 7. Seismic reflection profile across Resolution Guyot, taken by the Thomas Washington during Roundabout Leg 10. Locations of Sites 866,867 , and 868 were projected to this line from their actual locations approximately 0.5 to $1.2 \mathrm{nmi}(0.9$ to $1.9 \mathrm{~km})$ to the east.

Figure 8. Site 866 hole summary, including age, lithology, core recovery, physical properties, and downhole logs. Measurements of velocity on discrete samples are labeled for direction: Vpu is unoriented; Vpt (A) is transverse (horizontal) in Hole 866A; Vpl (A) is longitudinal (parallel to core axis) in Hole 866A; Vpt (B) is transverse in Hole 866B; $\mathrm{Vpl}(\mathrm{B})$ is longitudinal in Hole $866 \mathrm{~B}$.

Figure 9. Summary of igneous rocks cored in Hole 866A:

Figure 10. Site $867 / 868$ hole summary.

Figure 11. Location of Site 869. Bathymetry shown in hundreds of meters. Supplementary 50-m contours are shown by dashed lines. Seismic profile A-A' is shown in Figure 12.

Figure 12. Seismic profile across Site 869. Profile taken by the Thomas Washington in January 1992 on cruise TUNE08WT. See Figure 11 for location.

Figure 13. Site 869 hole summary, including age, lithology, core recovery, physical properties and downhole logs.

Figure 14. Location of Site 870 in Anewetak lagoon. 


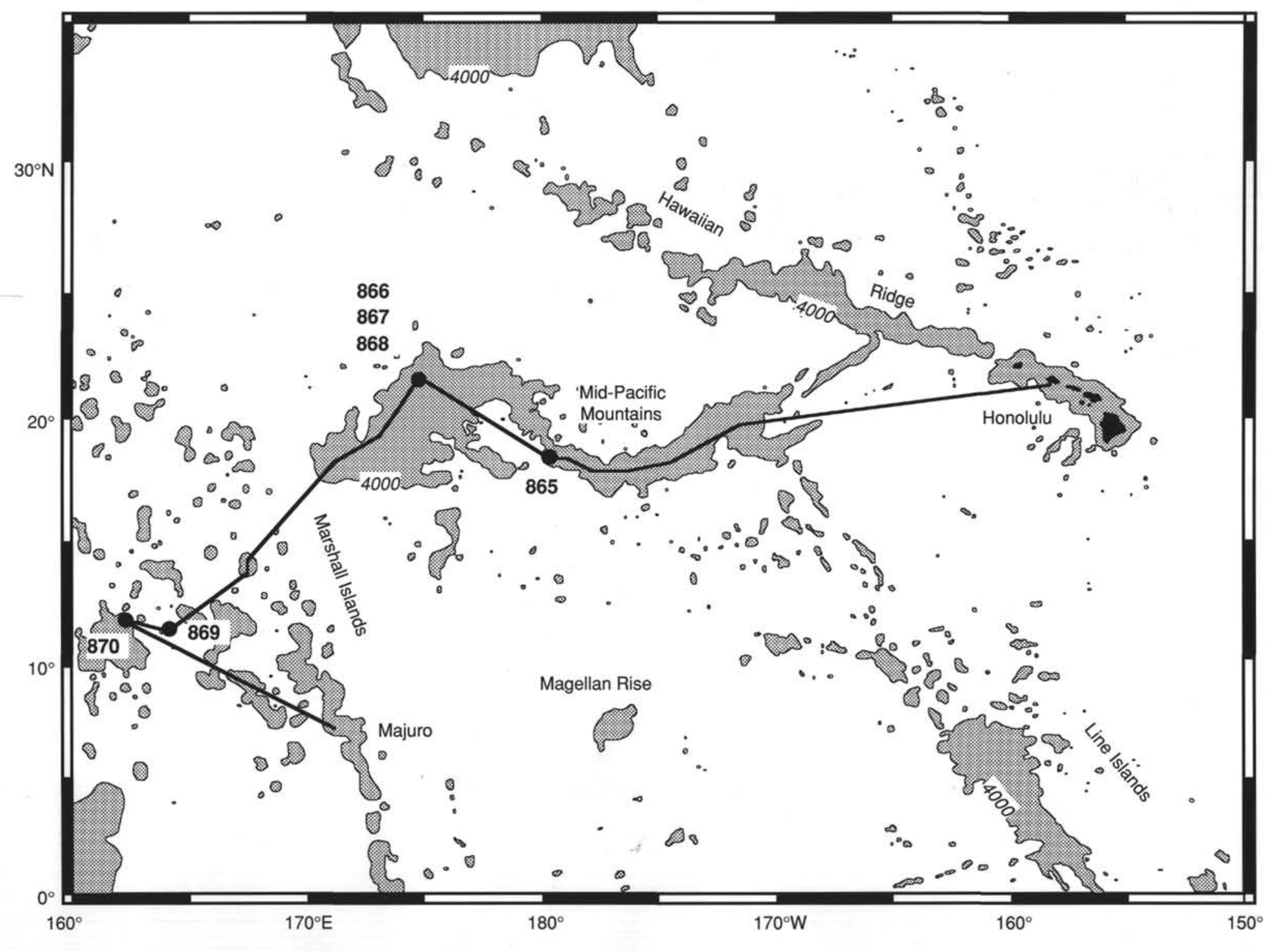

Figure 1

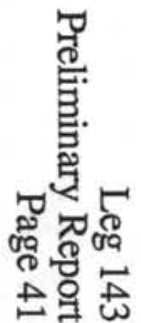




\section{Leg 143}

\section{Preliminary Report}

\section{Page 42}

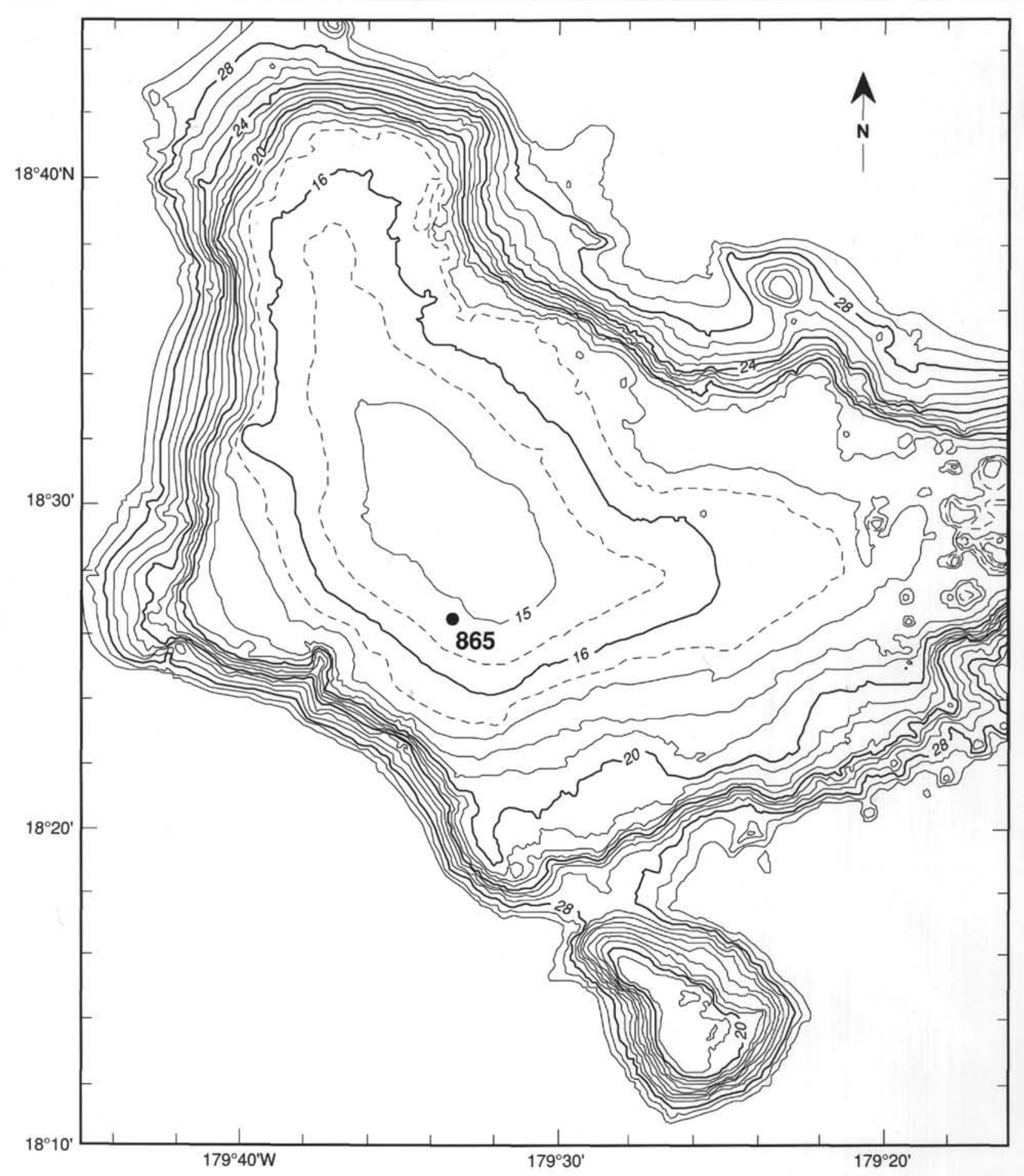

Figure 2 


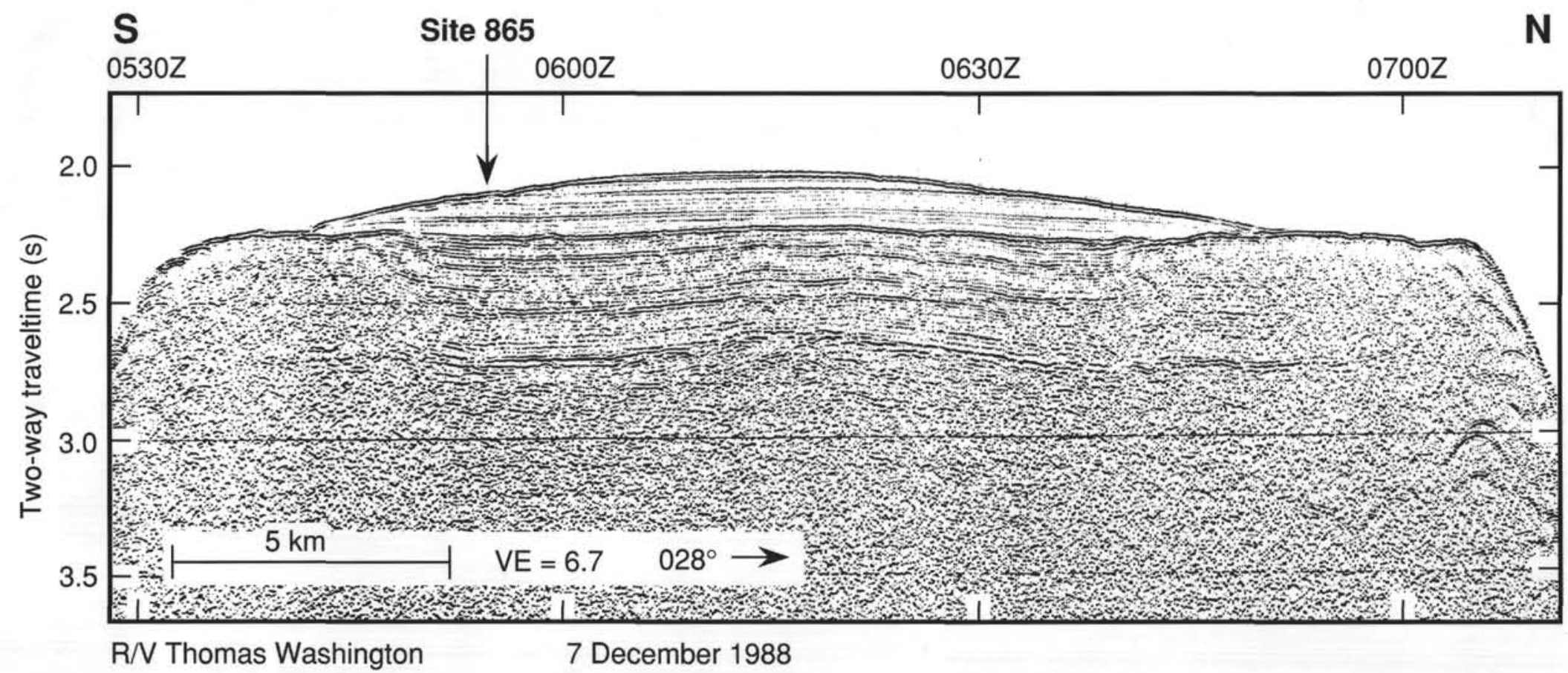

Figure 3

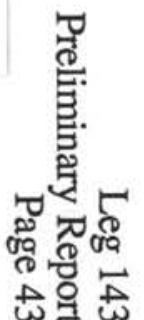


Leg 143

Preliminary Report

Page 44

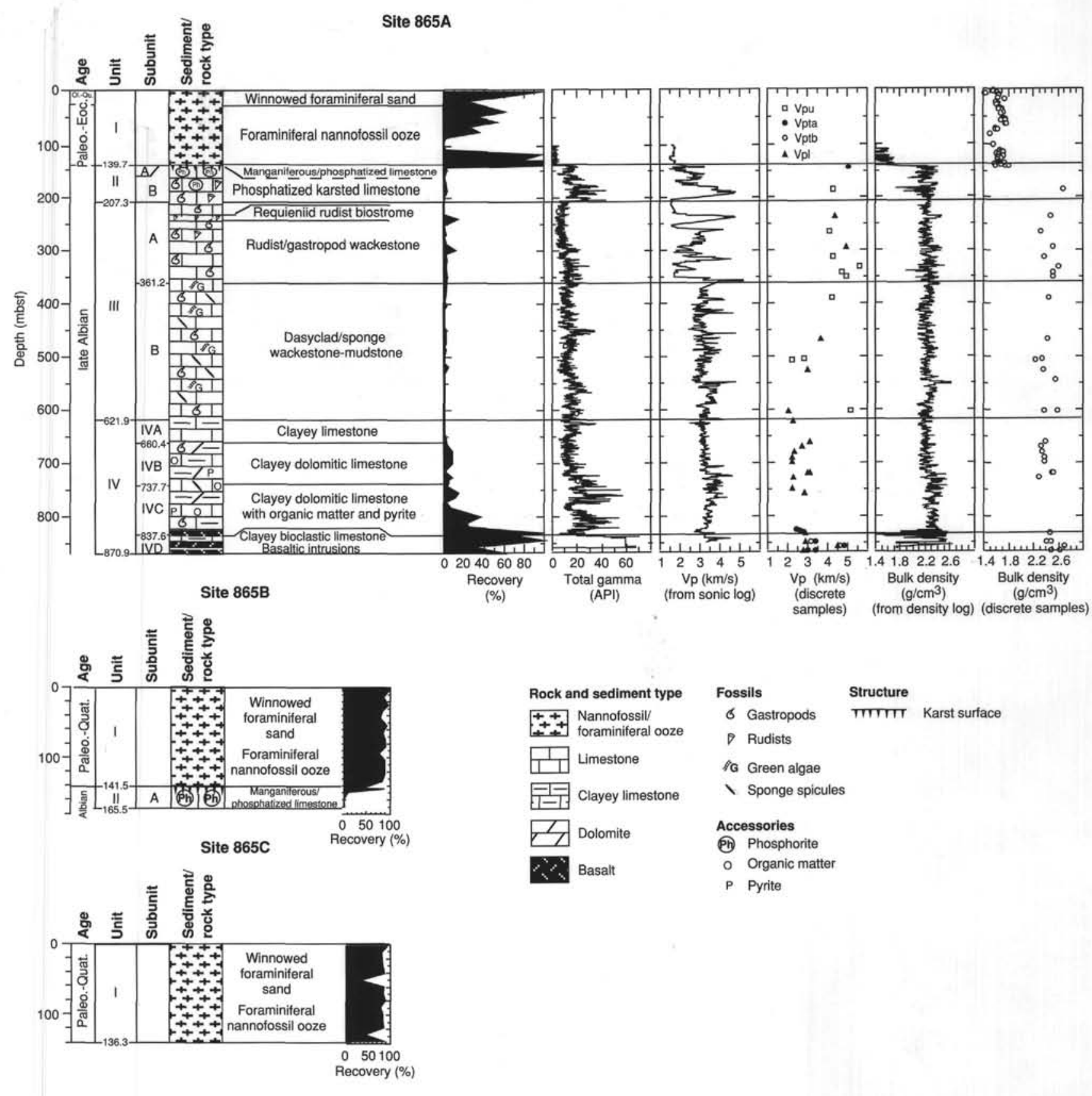

Figure 4 


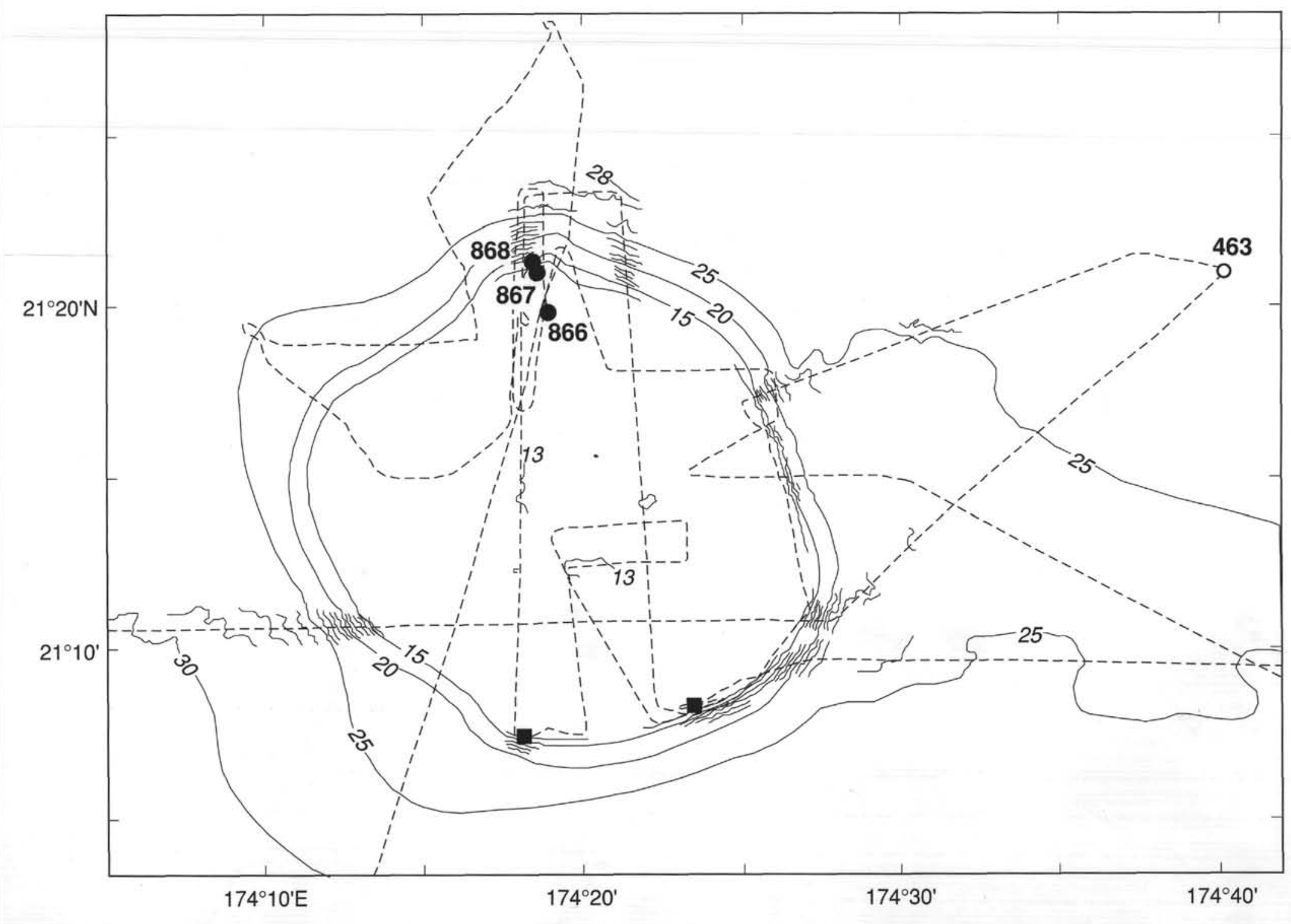

Figure 5

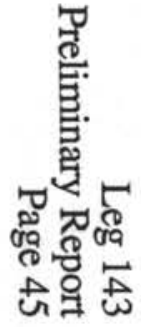




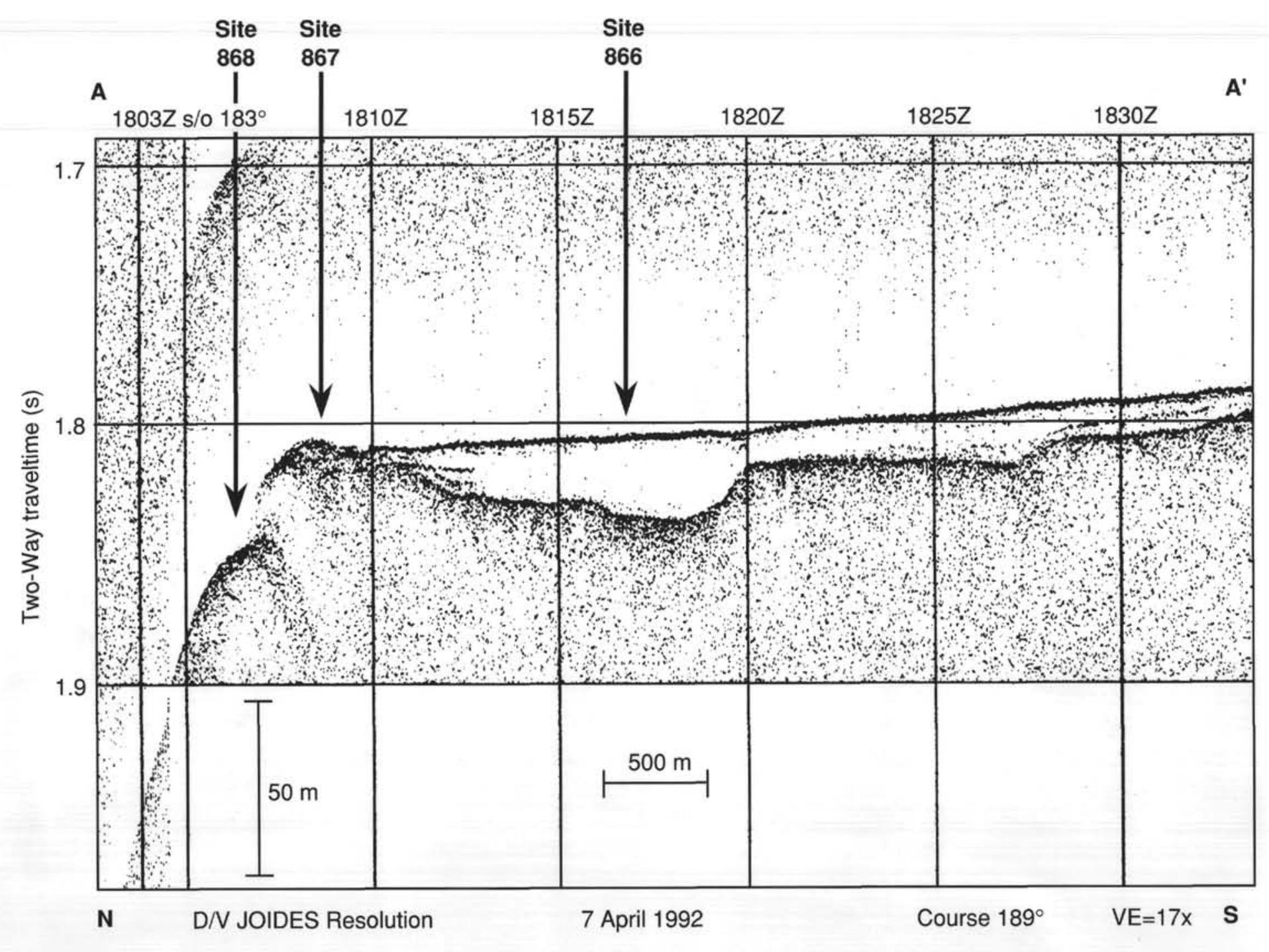

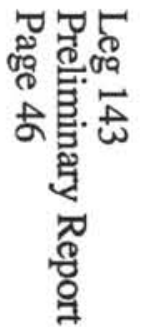

Figure 6 


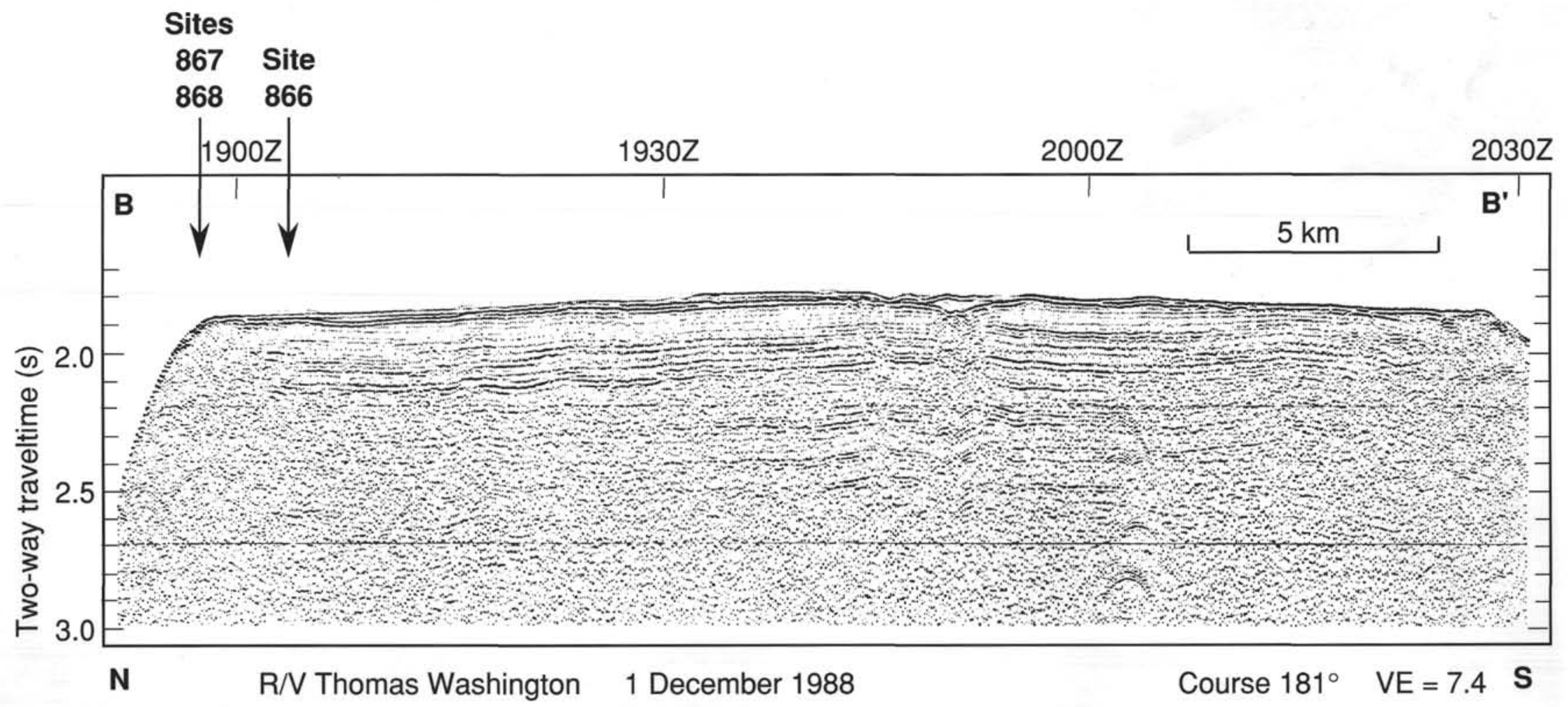

Figure 7

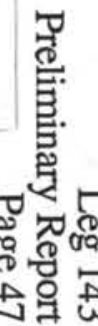




\section{Leg 143}

\section{Preliminary Report}

Page 48

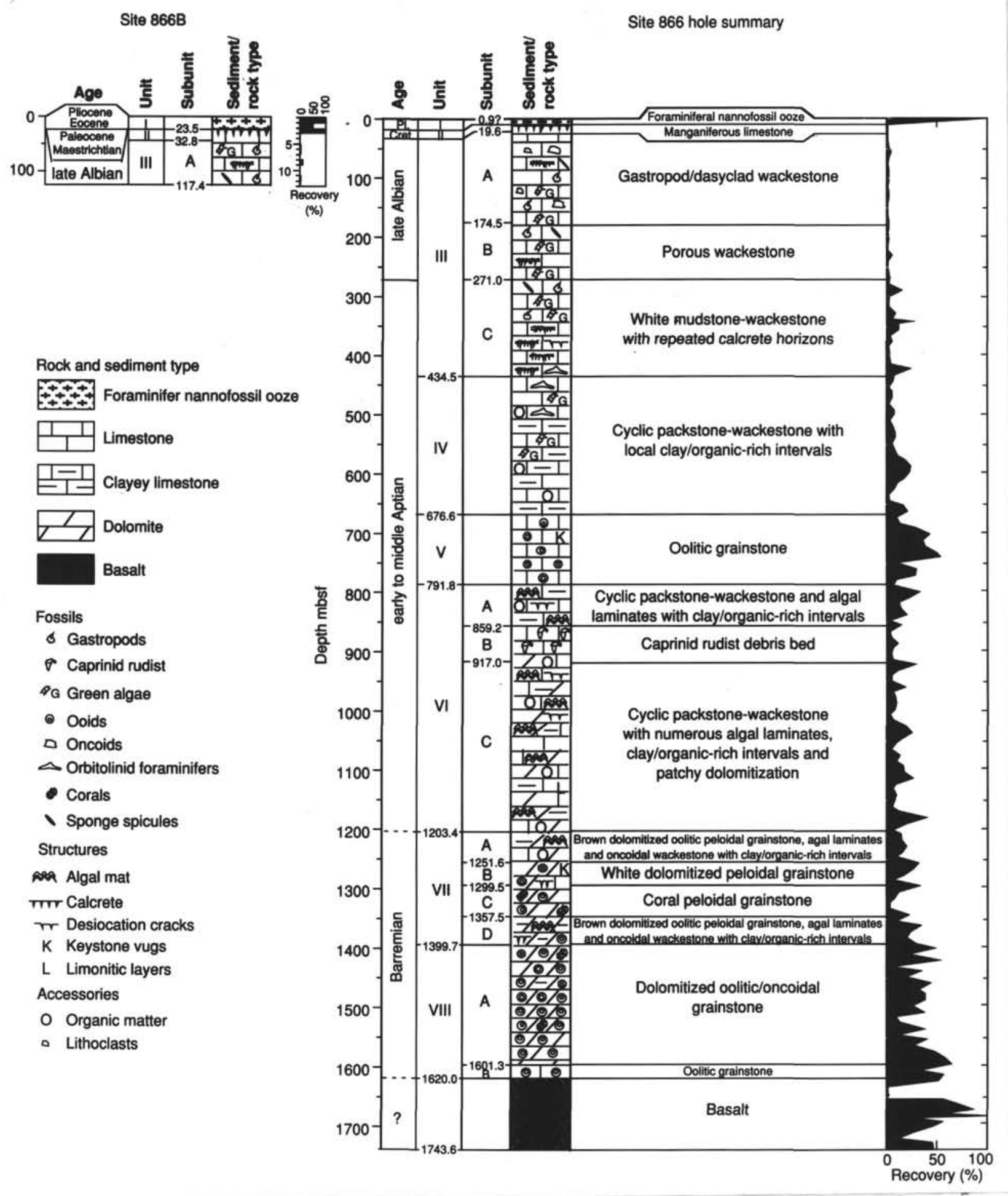

Figure 8 (Part I) 
Leg 143

Preliminary Report

Page 49

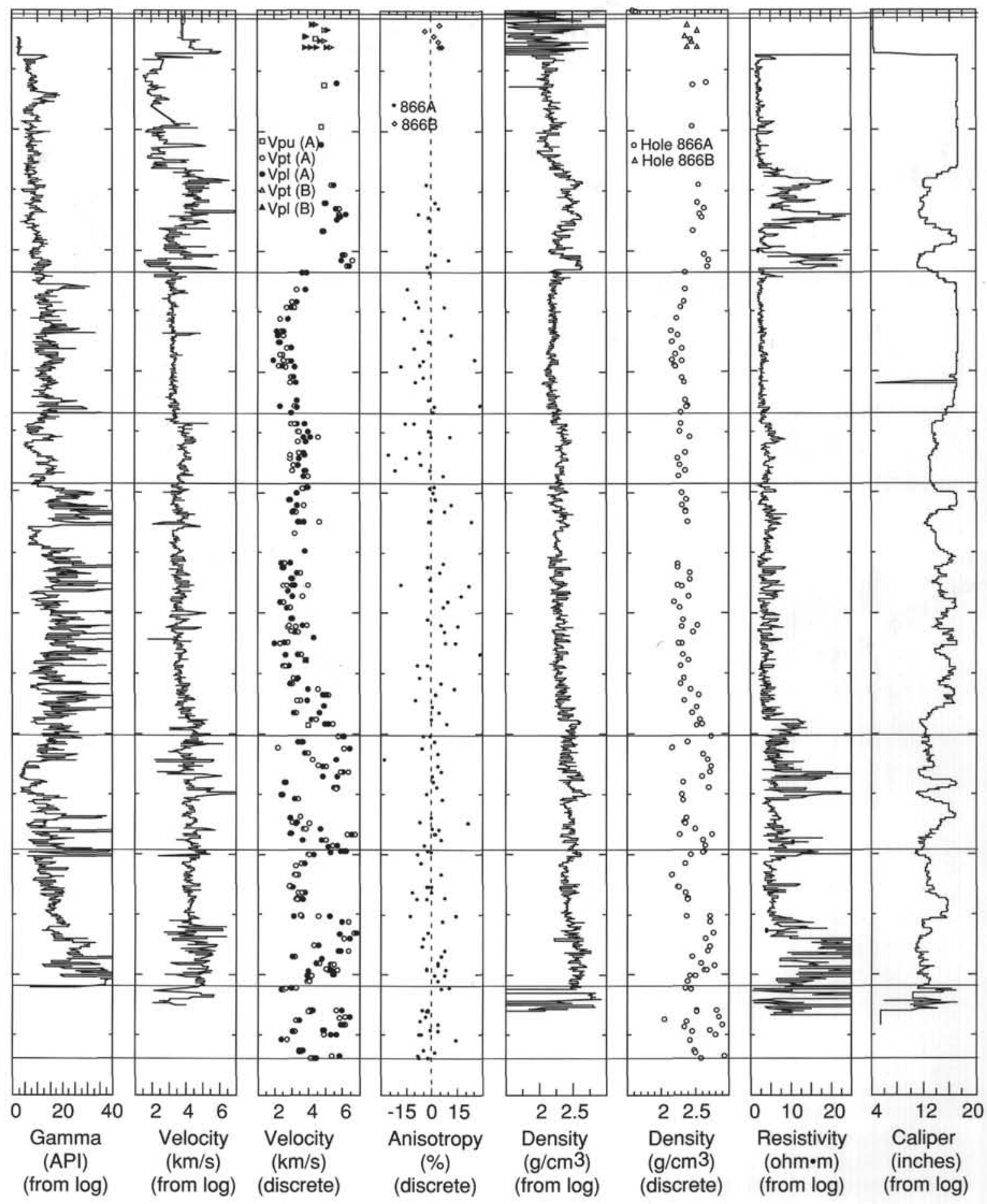

Figure 8 (Part II) 
Leg 143

Preliminary Report

Page 50

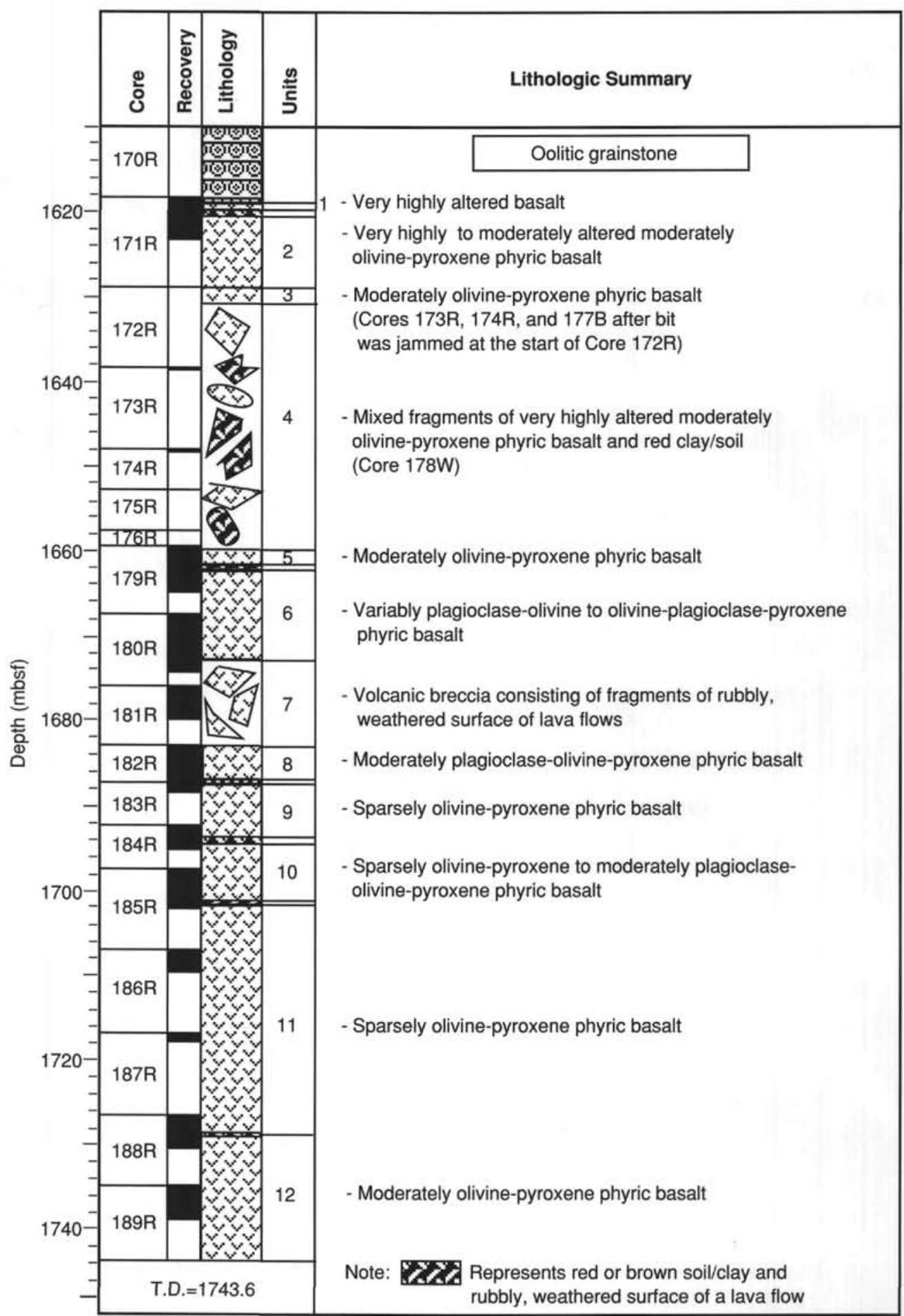

Figure 9 


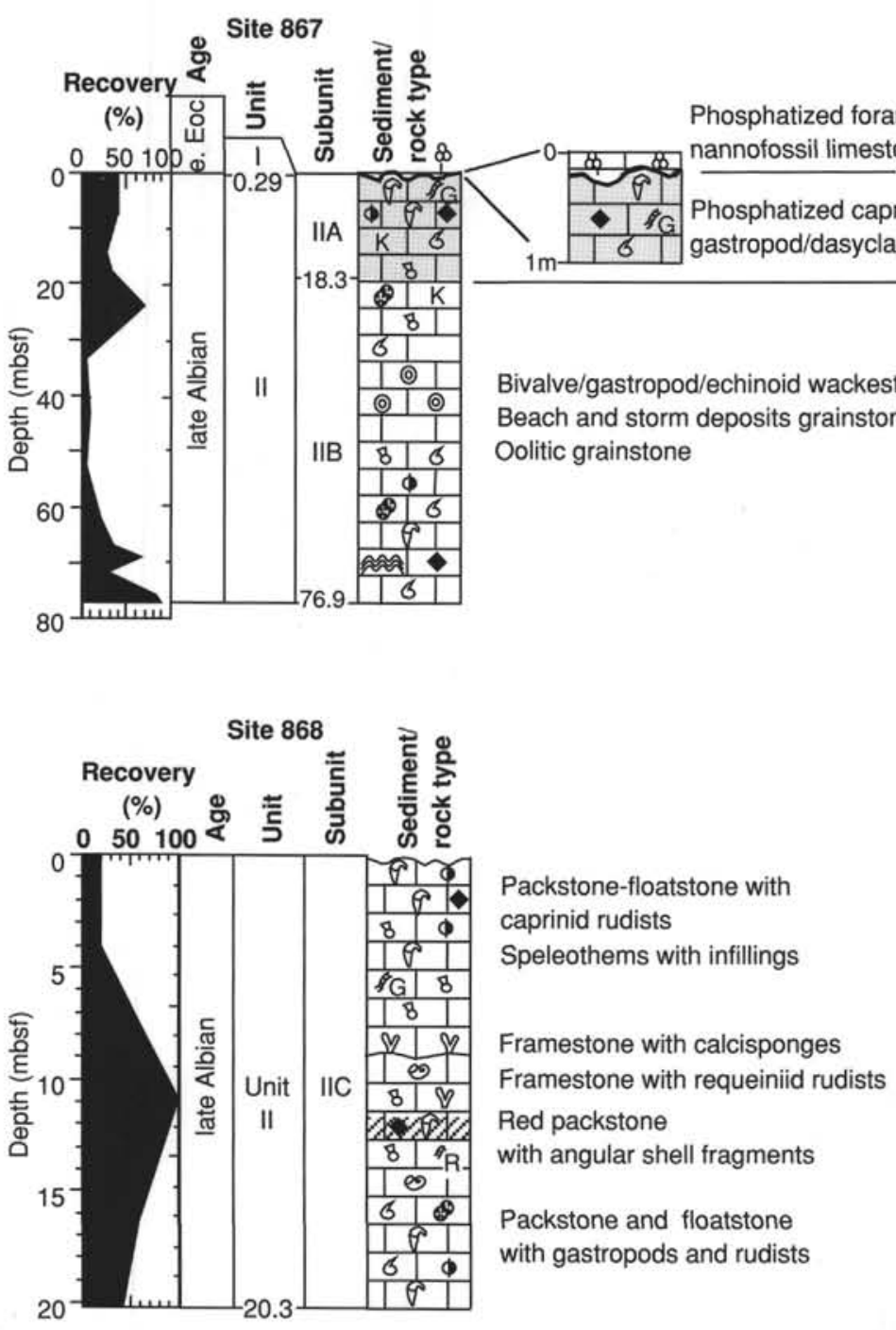

Rock \& sediment type

\&ा\& Foraminiferal nannofossil

$|8|$ limestone

प1 Limestone

$\square$ Limestone with

(1) diffuse phosphatization

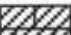

Red limestone

Fossils

6 Gastropods

$\uparrow$ Caprinid rudists

e Requieniid rudists

8 Other bivalves

- Corals

G Green algae

'R Red algae

$\checkmark$ Calcisponges

- Benthic foraminifers

\& Pelagic foraminifers

\section{Structures}

(๑) Ooids

Algal mat

K Keystone vugs

\section{Accessories}

- Black pebbles

Figure 10 
Leg 143

Preliminary Report

Page 52

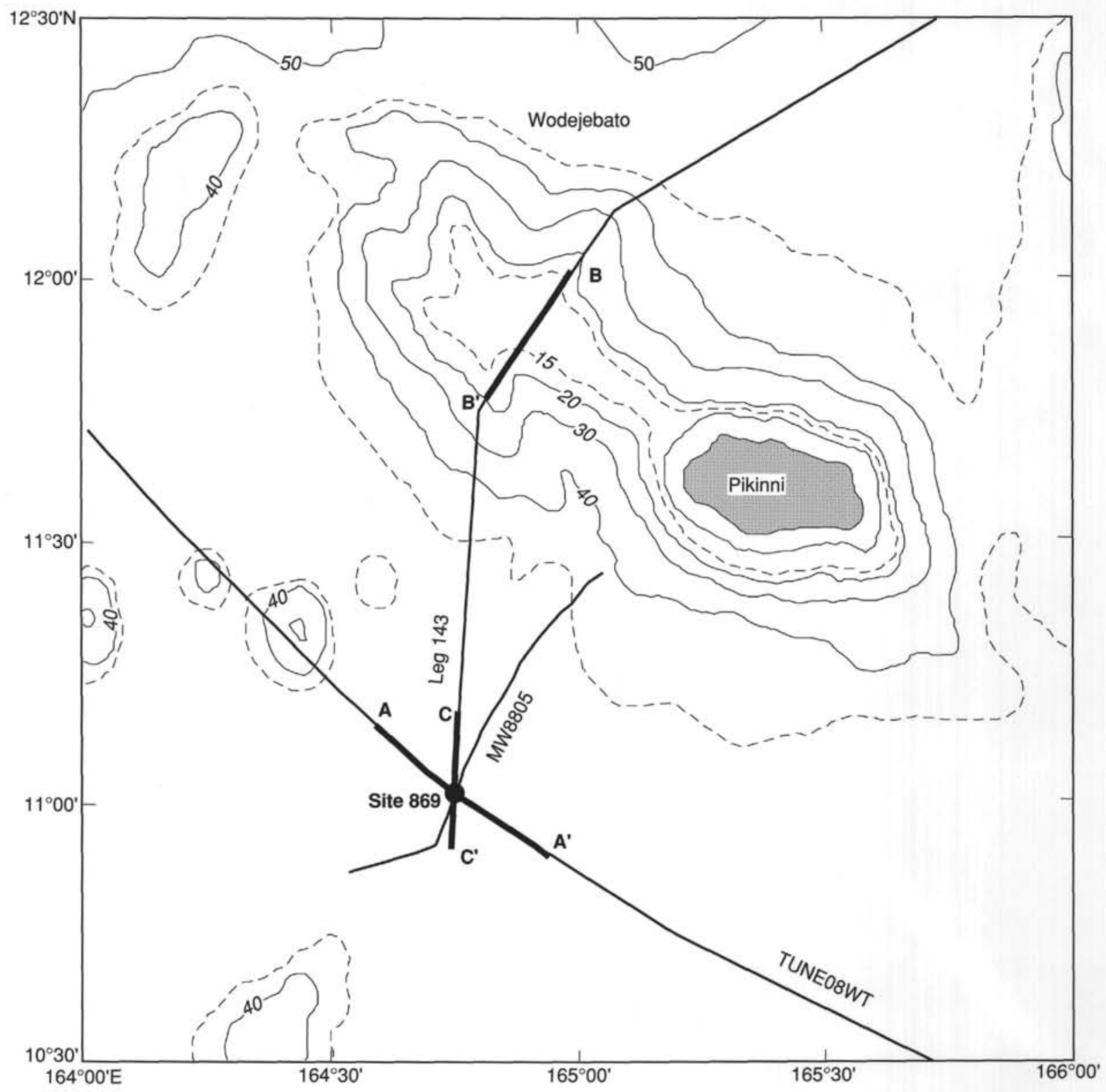

Figure 11 


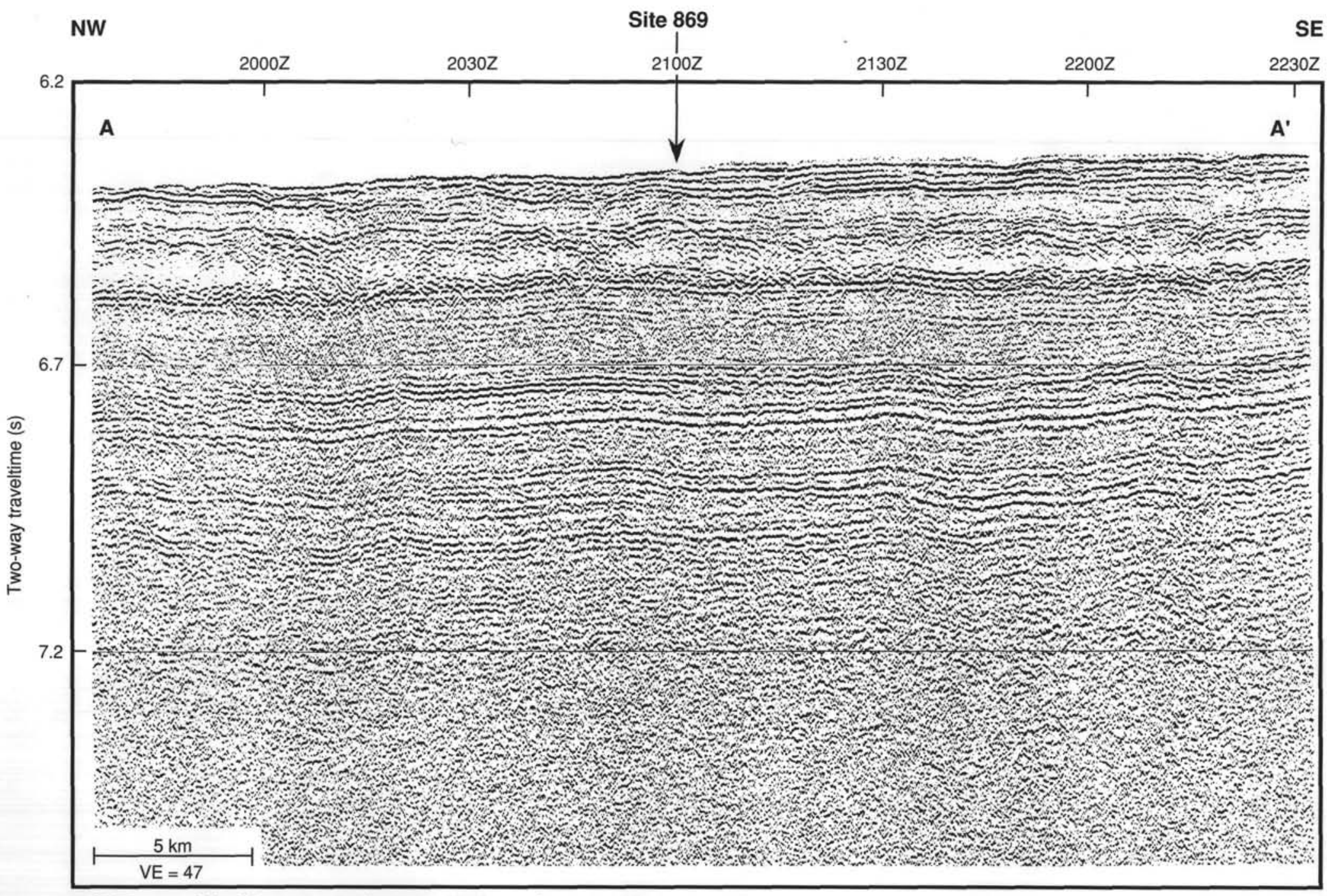

R/V Thomas Washington 29 January 1992

Course $133^{\circ}$

Figure 12 


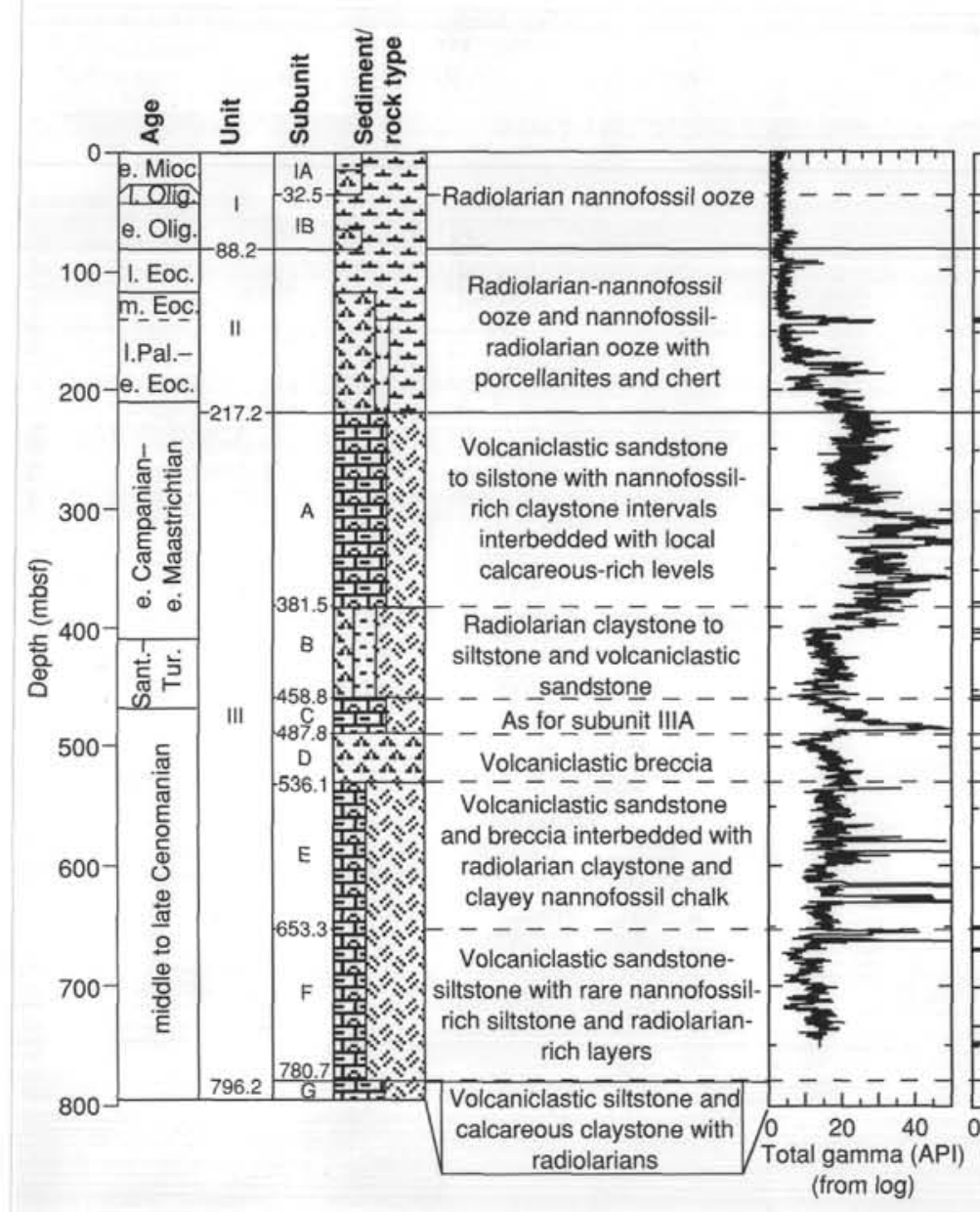

Site 869

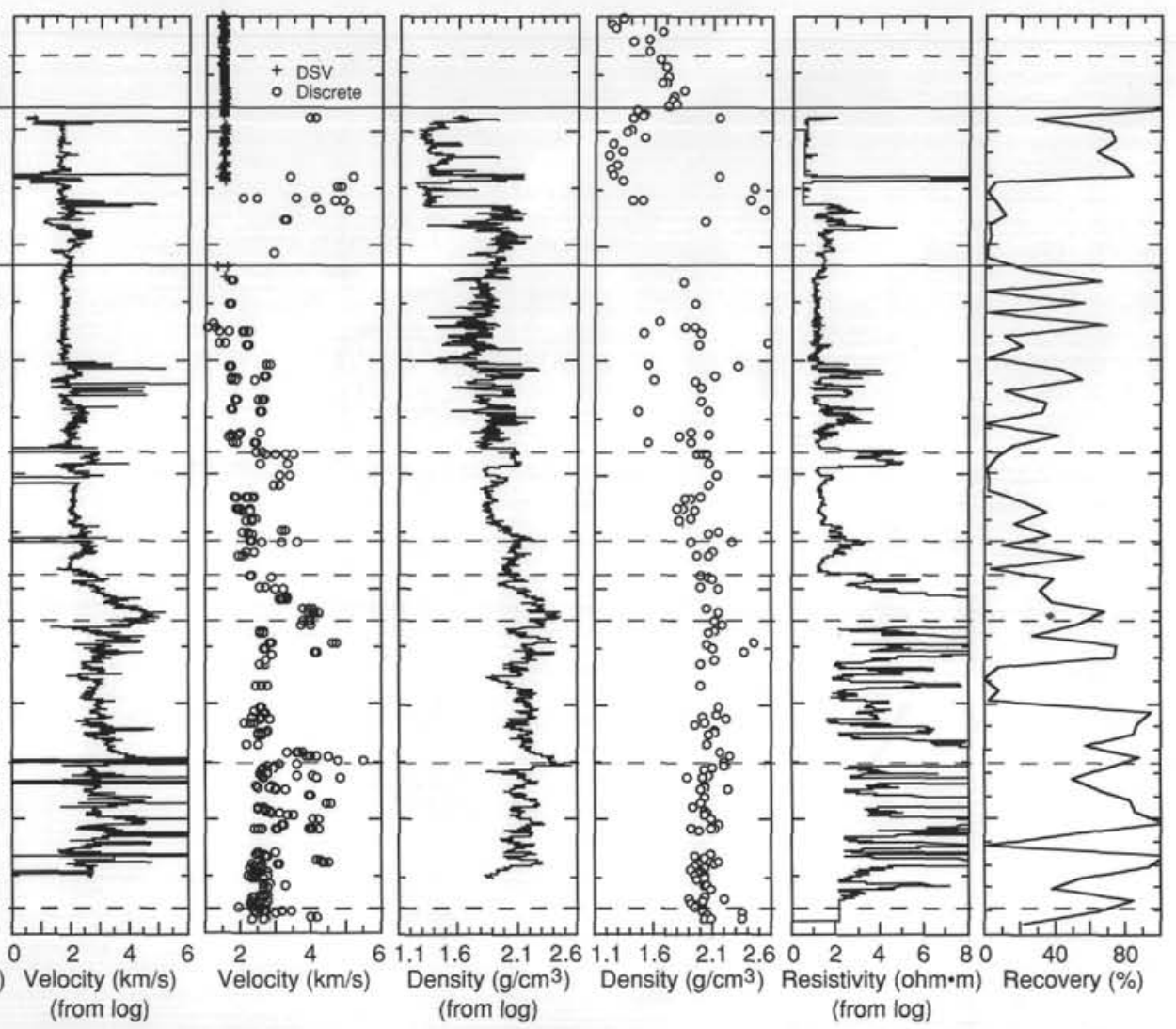

क्षै

क

台豆. 岕

焉

శ్ర

Figure 13 
Leg 143

Preliminary Report

Page 55

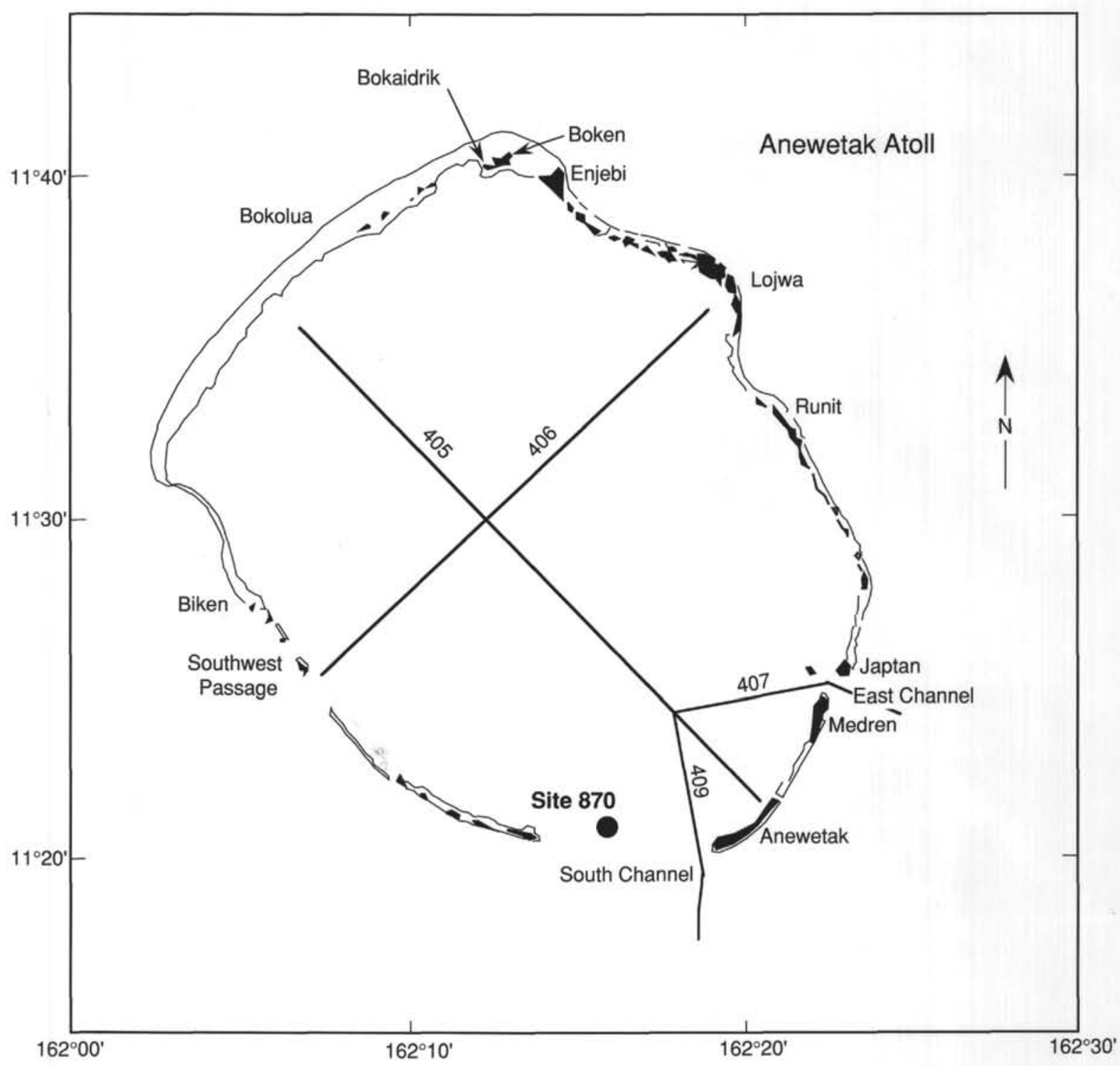

Figure 14 
OPERATIONS REPORT 
Leg 143

Preliminary Report

Page 58

The ODP Operations and Engineering personnel aboard JOIDES Resolution for Leg 143 were:

Operations Superintendent:

Development Engineer:

Schlumberger Engineer:

LDGO Logging Technician:
Eugene Pollard

William Rhinehart

David Ritz

Vladimir Kouzmin 
Leg 143

Preliminary Report

Page 59

\section{OVERVIEW}

Legs 143 and 144 of the Ocean Drilling Program were dedicated to drilling Cretaceous carbonatebearing guyots of the Western Pacific, with the objective of using them as monitors of relative sealevel changes and thereby of the combined effects of the tectonic subsidence (and uplift) history of the seamounts and of global fluctuations of sea level. The records from widely separated guyots would be compared to separate tectonic effects from eustatic effects. Cores from the volcanic edifice under the carbonate caps would provide data for estimating the paleolatitude of formation of the guyots and for assessing the long-term history of the Dupal isotopic anomaly in the Pacific. The Wodejebato (Sylvania) Guyot site was drilled on a sediment apron built during three stages of reef development on the adjacent guyot and atoll (Pikinni), and the Anewetak site in the lagoon of a living atoll was an engineering test to evaluate the ability of JOIDES Resolution to core in shallow water.

\section{HONOLULU, HAWAII, PORT CALL}

Leg 143 began with the first mooring line on Honolulu's Pier No. 1 at $1000 \mathrm{hr}, 18 \mathrm{March} 1992$ (local). The DCS (diamond coring system) was off-loaded onto trucks, and supplies, and 1839 MT (metric tons) of fuel, and drill water were taken on. DEC computer and Zeiss microscope service techs performed service calls. A new seismic levelwind was installed on the aft starboard reel. Drill collars and the 6-3/4-in. DCB (diamond core barrel) equipment were repositioned to accommodate the two hard rock bases, drill collars, 50 joints of 11-3/4-in. casing, and equipment loaded on board. Bulk trucks loaded 62 ST (short tons) of cement, 120 ST of barite, and 80 ST of gel on board. Divers changed out a bad transformer in the sonar dome, cleaned the Doppler sonar well, and measured the moon-pool opening. Two new Xerox machines were installed. An attempt to hook up a seaphone was unsuccessful because the PABX was incompatible. The cryogenicmagnetometer was loaded with liquid helium. Tours for students, the JOIDES Shipboard Measurements Panel, and other VIPs were completed. Extensive modifications were made to the shipboard core laboratory to improve core-handling flow.

The ODL (Overseas Drilling Ltd.) taut-wire system was serviced, and dynamic positioning system adjustments were made and tested. The no. 2 thruster pod pinion shaft was serviced. Divers completed a video-camera hull inspection for the ABS (American Bureau of Shipping), and the 
Leg 143

Preliminary Report

Page 60

props were cleaned. The helicopter fuel was changed out. Cargo-handling gear, radiotelegraph, and derating certifications were completed. Life rafts were inspected. The swivel and top drive was changed out, the heave compensator was repacked, and the Bowen wireline blow-out preventer was bored out to 4-1/8-in. Crane load cells were replaced, and the subsea shop received an ABS inspection, but additional documentation was required before certification. Port-call activities were completed, and the last line was onboard at $1500 \mathrm{hr}, 22 \mathrm{March}$.

\section{HONOLULU TO ALLISON GUYOT (SITE 865)}

The transit to Allison Guyot covered $1239 \mathrm{nmi}$ (nautical miles) in $109.5 \mathrm{hr}$ at an average speed of $11.4 \mathrm{kt}$ (knots). The magnetometer was deployed as soon as the ship was clear of port traffic. Despite the heavy fuel and consumables load ( $22.4 \mathrm{ft}$ draft), the ship made over $12.0 \mathrm{kt}$ with clean props, following 15-kt trade winds and 5-ft-high Force 5 moderate seas.

The ship's course was deflected slightly to run a 3.5-kHz and high-speed seismic survey over guyots near the ship's straight-line track. The high-speed seismic system with two 80 in 3 water guns was deployed at $0320 \mathrm{hr}, 25 \mathrm{March}$, and the ship's speed was reduced from 11.6 to $10.5 \mathrm{kt}$ to improve seismic record quality. The ship's clock was retarded $1 \mathrm{hr}$ from Hawaii time at $2400 \mathrm{hr}, 23 \mathrm{March}$.

A 29-nmi seismic survey was run over Allison Guyot in $5.75 \mathrm{hr}$ at $5.0 \mathrm{kt}$ to verify position. A sonobuoy was dropped about $10 \mathrm{mi}$ from the drill site on the edge of Allison Guyot. A Datasonics model 354B commandable release beacon, $14.0 \mathrm{kHz}, \mathrm{S} / \mathrm{N} 764$, was dropped at $0815 \mathrm{hr}, 27$ March.

\section{HOLE 865A}

The scientific objective at Allison Guyot was to investigate the history of the pelagic cap, date the pelagic/lagoonal facies contact, correlate limestone seismic reflectors with Resolution Guyot, and examine the subsidence history, sea-level cycles, and causes of drowning using lagoonal and backreef facies sediments. Due to previous coring problems in similar environments and uncertainty about lithological conditions, the 9-7/8-in. RCB (rotary core barrel) coring system was chosen for the first hole to assure deep penetration in the limestone, and evaluate hole conditions, 
Leg 143

Preliminary Report

Page 61

and determine if hard dolomites and cherts were present. The RCB hole would be logged, and if time permitted, an APC/XCB (advanced piston corer/extended core barrel) coring system would be used to sample soft upper sediments and evaluate the effectiveness of an alternate core-recovery system.

Heavy rust was noted in the drill collars, so the BHA (bottom-hole assembly) was circulated first without the inner barrel. The water depth was estimated at 1526.4 mbrf with the $3.5-\mathrm{kHz}$ PDR (precision depth recorder). A punch core taken with the RCB bit at $1534.8 \mathrm{mbrf}$ recovered $5.7 \mathrm{~m}$; therefore, the water depth was estimated at $1529.1 \mathrm{mbrf}$ (1518.4 mbsl).

To recover as much of the soft pelagic cover as possible, the soft nannofossil-foraminifer ooze was punch cored and dry cored with the RCB bit from Cores $865 \mathrm{~A}-1 \mathrm{R}$ to $-16 \mathrm{R}$ at $1529.1-1668.8 \mathrm{mbrf}$ (0.0-139.7 mbsf). A total of $139.7 \mathrm{~m}$ was cored, and $71.84 \mathrm{~m}$ was recovered for a recovery of $51.42 \%$. Most of the punch cores were unusually soft and deformed in the upper half of the hole; however, many of the lower cores appeared to be less disturbed. The core-barrel seals were checked as a precaution against internal APC seal failure, which could fluidize the core. The coring parameters were 0-10K lb WOB (weight on bit), 0-10 rpm, and 50-125 gpm (gallons per minute). Recovery improved again in nannofossil/foram ooze; however, the formation became noticeably harder during Core $865 \mathrm{~A}-17 \mathrm{R}$ (139.7-144.7 mbsf), and recovery was poor thereafter.

The shallow-water lagoonal limestone and marsh mudstone section from Cores $865 \mathrm{~A}-17 \mathrm{R}$ to $-85 \mathrm{R}$ at 1668.8-2324.9 mbrf (139.7-795.8 mbsf) was cored with 15-30K lb WOB, 10-60 rpm, and 125-200 gpm. After Core 865A-21R at 178 mbsf, the formation apparently caved in, causing high torque and overpull and plugging of the drill pipe.

Despite very low circulation rates (30\%-50\% of normal to avoid washing away the soft, friable core matrix) and heavy backflow up the pipe (the flapper valve was staying open), fill was negligible, and coring continued without incident in the lagoonal sediments. The hard limestone lumps that could be recovered were apparently in a softer, friable, water-sensitive carbonate matrix that was breaking up and washing away. Recovery was very poor (about 2\%) from 140 to $747 \mathrm{mbsf}$. All combinations of single and 4-pedal core catchers, hard, soft, and combination finger catchers, and operating parameters and techniques failed to improve recovery markedly or consistently. 


\section{Leg 143}

Preliminary Report

Page 62

A decision was made to expend additional time to deepen the hole to basement if possible at $500 \mathrm{mbsf}$. The formation got harder at $548 \mathrm{mbsf}$. Below Core 865A-70R at $650 \mathrm{mbsf}$, the lagoonal limestones had increasing mudstone and dolomite content grading to marl, and recovery improved to $7 \%$ on average. Basalt, red clay, and limestone interbeds were encountered in Core $865 \mathrm{~A}-90 \mathrm{R}$ at $840 \mathrm{mbsf}$, and recovery increased to a $43 \%$ average.

The entire HRO (hard rock orientation) system was tested with Cores $865 \mathrm{~A}-91 \mathrm{R}$ and $-94 \mathrm{R}$ for the first time. The HRO system consists of the SCM (sonic core monitor), tensor electronic orientation tool, and scribing core catcher. The SCM battery died in Core 865A-91R (847 mbsf), but the tensor and scribe shoe worked. All systems seemed to work in Core 865A-94R (871 mbsf); however, the tensor tool recorded some unstable readings that may have been caused by tool vibration, rotation, or the magnetic influence of the basalt. The tops of some cores were "lathed" by rotation in the scribe shoe, and other cores had multiple scribe marks, indicating several passes through the shoe. Hole angle was recorded at $1.9^{\circ}$ to $1.3^{\circ}$.

$\mathrm{RCB}$ coring was terminated with Core $865 \mathrm{~A}-94 \mathrm{R}$ at $2400.0 \mathrm{mbrf}(870.9 \mathrm{mbsf})$ at $0330 \mathrm{hr}$, 1 April. The 9-7/8-in. RBI C-4 bit was dropped with the MBR (mechanical bit release), the sleeve was shifted, and the pipe was pulled to $1629 \mathrm{mbrf}(100 \mathrm{mbsf})$ to $\log$.

Log no. 1: NGT (natural gamma ray tool)/CNT (neutron porosity tool)/HLDT (hightemperature lithodensity tool)/DIT (phasor induction tool). LDGO (Lamont-Doherty Geological Observatory) elected to run the SDT (sonic digital logging tool) on the bottom of the string for safety so the nuclear tools could still be recovered in case the tool parted. The tool string lost telemetry when the sonic tool was turned on; therefore, the sonic tool was laid out for $\log$ no. 1. It was determined later that the sonic tool could be run only on top of this configuration with the present equipment. The DIT and NGT were logged while running in from 1579 to 2398 mbrf (no fill above the MBR and bit). The cable head failed when an attempt was made to $\log$ up. The $\log$ required $4.25 \mathrm{hr}$.

Log no. 2: Magnetometer. The sonic log was considered critical for seismic-velocity verification, and the problem was unclear; therefore, the 150-lb Ocean Research Institute (Tokyo University) magnetometer (which has a self-contained memory and Gearhart connection) was run next to allow Schlumberger time to troubleshoot the sonic tool. 
Leg 143

Preliminary Report

Page 63

The magnetometer was logged down from 2029 to $2395 \mathrm{mbrf}$ ( $3 \mathrm{~m}$ fill above the MBR) and up from 2395 to $2029 \mathrm{mbrf}$. The log required $4.5 \mathrm{hr}$.

Log no. 3 (RR Log No. 1): HLDT/CNT/SDT/NGT. The logging cable was reheaded, and the sonic tool was run on top of the string. The logs were run from 2393 to $1629 \mathrm{mbrf}$ ( $5 \mathrm{~m}$ fill above the MBR) and required $6 \mathrm{hr}$.

Log no. 4: GST (induced spectral gamma-ray tool)/ACT (aluminum clay tool)/CNT/NGT (geochemical). The geochemical tool would not calibrate downhole (at $\left.2^{\circ} \mathrm{C}\right)$; therefore, it was pulled back to the surface (where it calibrated all right again at $20^{\circ} \mathrm{C}$ ). Apparently the tool will not calibrate at low temperatures. The log was run from 2370 to $1629 \mathrm{mbrf}$ and required $10 \mathrm{hr}$. The TD (total depth) was at $2381 \mathrm{mbrf}$ ( $17 \mathrm{~m}$ fill above the MBR).

Log no. 5: NGT/GPIT (general purpose inclinometer)/FMS (formation microscanner). The FMS log was run from 2379 to $1627 \mathrm{mbrf}$ ( $19 \mathrm{~m}$ fill above the MBR) and required $6 \mathrm{hr}$.

Hole conditions were good except for severe hole enlargement in the top half of the hole (despite low circulation rates). Hole conditioning and logging required $43.5 \mathrm{hr}$. The drill collars cleared the seafloor at $2315 \mathrm{hr}, 2$ April, ending Hole 865A.

\section{HOLE 865B}

The ship was moved $20 \mathrm{~m}$ north while the RCB core barrel from Hole $865 \mathrm{~A}$ was pulled and laid down. A PDR check indicated the water depth was 1527.4 mbrf. An APC/XCB BHA was run. The purpose of Holes $865 \mathrm{~B}$ and $865 \mathrm{C}$ was to obtain a good double-APC sample of the Eocene/Paleocene boundary as well as additional cores from the manganese-nodule-encrusted surface of the Cretaceous limestone.

The bit was positioned at $1526 \mathrm{~m}$, and Core $865 \mathrm{~B}-1 \mathrm{H}$ was taken. The core recovered $8.51 \mathrm{~m}$; therefore, the water depth by DPM (drill pipe measurement) was $1527 \mathrm{~m}$. APC Cores $865 \mathrm{~B}-1 \mathrm{H}$ to $14 \mathrm{H}$ were taken from 1527.0 to $1659.0 \mathrm{mbrf}(0.0-132.0 \mathrm{mbsf})$ with $132.0 \mathrm{~m}$ cored and $118.98 \mathrm{~m}$ recovered ( $90.14 \%$ recovery). Pore water samples were obtained with the WSTP (water sampler temperature probe) after Core 865B-6H (56.0 mbsf), Core 865B-13H (no sample was obtained 
Leg 143

Preliminary Report

Page 64

because the WSTP latch stuck in the drill pipe), and Core 865B-14H (132.0 mbsf). The backup Uyeda temperature recording package failed $6 \mathrm{~min}$ into the first run at $56.0 \mathrm{mbsf}$ (possibly a thermistor failure). The primary Uyeda temperature tool had been lost on Leg 141. An Adara APC temperature shoe was available.

The deeper APC cores were unusually soft and contained much water, however, the cores were no more disturbed than normal, and a check of the APC seals provided no substantive mechanical explanation for the problem. Therefore, the pelagic cap appears simply to have retained more water than normal.

To obtain a sample of the phosphatized, karstified, manganese-encrusted limestone surface, $\mathrm{XCB}$ Cores $865 \mathrm{~B}-15 \mathrm{X}$ to $-19 \mathrm{X}$ were taken from 1659.0 to $1692.5 \mathrm{mbrf}$ (132.0-165.5 mbsf), with $33.5 \mathrm{~m}$ cored and $4.68 \mathrm{~m}$ recovered (13.97\% recovery). The hard layer was encountered at $141.5 \mathrm{~m}$ in the bottom of Core 865B-15X. Core 865B-15X was the first test of the XCB horizontal jet coring shoe and 4-pedal flapper core catcher designed specifically to core soft sediments, and it recovered $3.87 \mathrm{~m}$ of soft nanno ooze in a $9.5 \mathrm{~m}$ core ( $40.74 \%$ recovery). The bit cleared the seafloor at $0130 \mathrm{hr}, 4$ April, ending Hole 865B.

\section{HOLE 865C}

The ship was moved $20 \mathrm{~m}$ north, and Hole $865 \mathrm{C}$ (Site All-A) was spudded at $0215 \mathrm{hr}, 4$ April. The bit was at $1522 \mathrm{~m}$ for Core $865 \mathrm{C}-1 \mathrm{H}$ and $3.32 \mathrm{~m}$ was recovered; therefore, the seafloor was at $1528.2 \mathrm{mbrf}$. APC Cores $865 \mathrm{C}-1 \mathrm{H}$ to $-15 \mathrm{H}$ were taken from 1528.2 to $1664.5 \mathrm{mbrf}$ (0.0-136.3 mbsf) with $136.3 \mathrm{~m}$ cored and $113.39 \mathrm{~m}$ recovered ( $83.19 \%$ recovery). The bit was pulled and cleared the rotary table at $1415 \mathrm{hr}, 4$ April, ending Hole $865 \mathrm{C}$.

\section{TRANSIT FROM ALLISON GUYOT TO RESOLUTION GUYOT}

A 200 -in ${ }^{3}$ water gun (with 80 -in 3 backup), seismic gear, and magnetometer were deployed upon departing Hole $865 \mathrm{C}$. A sonobuoy was dropped, and a $25-\mathrm{nmi}$ seismic survey was run in $4 \mathrm{hr}$ over Allison Guyot at $6.25 \mathrm{kt}$. The transit to Resolution Guyot covered $360 \mathrm{nmi}$ in $33.75 \mathrm{hr}$ at an average speed of $10.7 \mathrm{kt}$. The calendar was advanced 1 day on crossing the International 
Leg 143

Preliminary Report

Page 65

Date Line at $1200 \mathrm{hr}, 5$ April, to $1200 \mathrm{hr}, 6$ April, which left the ship on Majuro Daylight Savings Time for the rest of Leg 143.

The 3.5-kHz seismic control panel failed shortly after leaving Allison Guyot, and the $10 \mathrm{~kW}$ unit could not be repaired despite a herculean effort by the ODP ETs (electronics technicians). The old, original $2 \mathrm{~kW}$ equipment was wired-in, and the $3.5-\mathrm{kHz}$ instrument was working as Resolution Guyot was approached. The zig-zag survey over the reef rim of Resolution Guyot covered $33 \mathrm{nmi}$ in $6 \mathrm{hr}$ at $5.5 \mathrm{kt}$. A thicker sediment cover than the $25 \mathrm{~m}$ cover at site Hue-A could not be found; however, the Co-Chiefs wanted to position the hole closer to the guyot rim, so the beacon for Hole $866 \mathrm{~A}$ was dropped closer to the rim in approximately $25 \mathrm{~m}$ of sediment at a site about $1.9 \mathrm{~km}$ to the east of proposed site Hue-A. The Datasonics model 354B beacon was dropped at $0930 \mathrm{hr}$, 7 April.

\section{HOLE 866A}

Hole $866 \mathrm{~A}$ was intended to be a deep penetration into the volcanic basement under Resolution . The hole depth was estimated at $850 \mathrm{~m}$ in the Prospectus; however, using seismic velocities from Allison Guyot, the basement depth was recalculated at $950 \mathrm{~m}$, and a $200-\mathrm{m}$ basement penetration was planned. Although the RCB system was plagued by poor recovery at Allison Guyot, the RCB system was chosen again as the coring tool most likely to produce a successful deep penetration in the hard limestones anticipated at Resolution.

The same RCB BHA was run, and Hole $866 \mathrm{~A}$ was spudded at $1330 \mathrm{hr}, 7$ April. The mud line was estimated with the PDR at $1364.4 \mathrm{mbrf}$. An RCB punch core to $1373.5 \mathrm{~m}$ recovered $0.91 \mathrm{~m}$ for a mud line measurement of 1372.6 mbrf. Cores $866-3 R$ to $-4 R$ (10.2-28.9 mbsf) were cut with $0-5 \mathrm{~K}-\mathrm{lb}$ WOB, $10 \mathrm{rpm}$ and $50 \mathrm{gpm}$ at a ROP (rate of penetration) of $20-40 \mathrm{~min} /$ joint with rough rotation and torque in hard limestone crust. The drilling parameters were gradually increased as the BHA was buried. Recovery was $1 \%$ in limestone with a soft, friable, vuggy matrix. All types of core catchers, low circulation rate, dry coring, and all known drilling techniques failed to increase recovery on a consistent basis.

The first bit run was terminated at $917 \mathrm{mbsf}$ with 37.75 rotating $\mathrm{hr}$ as a precaution to eliminate a premature bit failure (this was the second run for this new bit model), to condition the hole after 
Leg 143

Preliminary Report

Page 66

6 days of coring, and to assure a fresh bit for deep penetration and basalt. The bit stuck at $223 \mathrm{mbsf}$, the rotary was stalled at $900 \mathrm{amps}$, and the string could not be freed with up to $150 \mathrm{~K} \mathrm{lb}$ overpull. Attempts to set the Hydrolex jars were not successful. A 30-bbl viscous mud pill was pumped, but the string came free while working the pipe. Two small ledges were noted while reaming through the stuck point. The four dog windows in the MBR lower sub were later found to have been deformed, indicating that the string was stuck at the bit. Only $3 \mathrm{~m}$ of fill was noted on returning to TD, so the hole remained in very good condition.

A FFF (free-fall funnel) was dropped, and the TV, sonar, and a beacon were run to determine the condition of the FFF in the unusually soft ooze and determine the exact offset coordinates of the hole from the positioning beacon. Variable $0.5-2$-kt currents had been affecting offsets. Two of three floats were visible above the impact crater (a hole was visible for the third), and the FFF rim was buried about $2 \mathrm{~m}$ below the visible seafloor. The BHA was pulled out.

The TV was run for the reentry, and the first three reentry attempts resulted in the bit rolling out of the FFF and stopping on hard limestone at $11 \mathrm{mbsf}$ on the side of the FFF without a float visible. On the assumption that the FFF was tilted, the fourth reentry attempt was made on the high side of the crater and was successful.

The current was variable, averaging about $0.5 \mathrm{kt}$ from $100^{\circ}$, but it ran from a few hours up to 6 days at $2 \mathrm{kt}$ from $50^{\circ}$ (speed estimated from forcing functions and visual observation of ship effects).

$\mathrm{RCB}$ coring continued from Cores $866 \mathrm{~A}-97 \mathrm{R}$ to $-165 \mathrm{R}$ (917.0-1569.3 mbsf) with recovery increasing from $10 \%$ to $28 \%$ in progressively harder limestones, oolitic grainstones, and wackestone/packstone with increasing dolomitic content. Erratic torque was noted on Core 866A$162 \mathrm{R}$ after 49.5 rotating $\mathrm{hr}$, and the rotary locked up on Core 866A-165R. The bit appeared to be failing, and only enough 5 -in. drill pipe had been run to reach $1650 \mathrm{mbsf}$; therefore, the bit was pulled to $1418 \mathrm{mbrf}$, and 20 stands of 5 -in. drill pipe was added. The TV was run to check the condition of the FFF, but the FFF was not visible in the cloudy ooze on bottom. The pipe appeared slightly off center in the crater, but sonar indicated the pipe was in the FFF. After reconsidering the risks involved, the pipe was pulled for a bit change. The 9-7/8-in. RBI C-4 spiral stabilizer RCB 
Leg 143

Preliminary Report

Page 67

bit showed junk damage (from 3 of 4 core guides that were broken off by contact with the bit cones as the bearings wore).

The reentry and trip in the hole were uneventful, and there was no evidence of undergage hole or junk. RCB coring continued from Cores $866 \mathrm{~A}-166 \mathrm{R}$ to $-171 \mathrm{R}$ (1569.3-1628.8 mbsf) with a $46.62 \%$ recovery in dolomitized oolitic grainstone and oolitic limestone. Highly altered basalt and red-brown clay were encountered at $1620 \mathrm{mbsf}$ in Core 866A-171R. After little or no recovery from Cores $866 \mathrm{~A}-172 \mathrm{R}$ through $-174 \mathrm{R}$, the pipe-type deplugger was dropped four times. Cores 866A-175R and -176R (1652.7-1659.4 mbsf) also recovered no core; therefore, the bit was pulled. The bit throat was plugged with two fist-sized unaltered basalt fragments and basalt gravel, but the bit was not damaged.

A 9-7/8-in. RBI C-7 bit, S/N BC753, was run with a new MBR and Hydrolex jars, and the reentry was uneventful, although the FFF was still not visible in the crater.

$\mathrm{RCB}$ coring continued with Cores $866 \mathrm{~A}-179 \mathrm{R}$ to $-188 \mathrm{R}$ (1659.4-1735.9 mbsf), with $48.85 \%$ recovery in altered basalt and red-brown clay. After dropping the core barrel for Core $866 \mathrm{~A}-189 \mathrm{R}$ and making the connection, the string started sticking, indicating that the hole had sloughed and packed-off. The hole was eventually circulated clean with $170 \mathrm{bbl}$ of viscous mud sweeps, and a short trip was made to $100 \mathrm{~m}$ above the top of the basalt at $1520 \mathrm{mbsf}$. Two additional cores were needed for paleomagnetic determinations. Core 866A-189R was cut from 1735.9-1743.6 mbsf without incident; however, because of poor hole conditions, coring was terminated at this time. A more accurate water-depth reading taken on the next hole indicates that Hole 866A may actually be $15 \mathrm{~m}$ deeper than reported. A conditioning trip was made to $80 \mathrm{mbsf}$ to prepare the hole for logs.

The bit was dropped with the MBR, the sleeve was shifted, and the pipe was pulled to $1472 \mathrm{mbrf}$ (100 mbsf) to log.

Log no. 1: NGT/SDT/CNT/HLDT/DIT/LTL (LDGO temperature tool)/TCC (telemetry cartridge). The tool was recorded down from 230.0 to $679.4 \mathrm{mbsf}$ and up from 1679.4 to $74.5 \mathrm{mbsf}$ to $20 \mathrm{mbsf}$ ) and required $7.5 \mathrm{hr}$. The tool was worked down through four obstructions from $3020 \mathrm{mbrf}$ and started sticking at $3048 \mathrm{mbrf}$; therefore, logging was commenced from that point. The unstable weathered basalt and red-brown clay appeared to 


\section{Leg 143}

Preliminary Report

Page 68

have sloughed into the hole again, despite four reamings. There was no hope of stabilizing the hole, and conditions appeared to be deteriorating.

Log no. 2: NGT/GPIT/FMS/LTL. The tool was logged from 1639.5 to $1527.0 \mathrm{mbsf}$, 1635 to $253 \mathrm{mbsf}$, and 354 to $253 \mathrm{mbsf}$ and required $8.5 \mathrm{hr}$.

Log no. 3: Magnetometer. The tool was recorded from 1645.5 to $1589 \mathrm{mbsf}$ and required $2.5 \mathrm{hr}$.

Log no. 4: Digital BHTV (borehole televiewer). The logs were recorded from 1640.5 to $260 \mathrm{mbsf}$ and required $9.5 \mathrm{hr}$. The data from this log was lost, however, due to a procedural error with the computer that was to read the data.

Log no. 5: GST/ACT/CNT/NGT (geochemical)/LTL. The log was recorded from 1626.4 to $925 \mathrm{mbsf}$ and required $13 \mathrm{hr}$. The tool was rerun from 1028 to $45 \mathrm{mbsf}$ because readings indicated the calibration settings had drifted, and from 175 to $45 \mathrm{mbsf}$ for quality control.

Hole conditions were good above the basalt at $1620 \mathrm{mbsf}$ except for severe hole enlargement in the top half of the hole. Hole conditioning and logging required $61 \mathrm{hr}$. The drill collars cleared the rotary table at $0730 \mathrm{hr}, 24 \mathrm{April}$, ending Hole $866 \mathrm{~A}$.

\section{HOLE 866B}

The poor recovery with the 4-cone RCB bits in the previous holes prompted an attempt to improve recovery using a rotary core barrel with an $\mathrm{RCB}$ wireline retrievable inner barrel and surface-set diamond bit. A 7-1/4-in. Longyear surface-set carbonado diamond bit was used. A punch core to $1363.1 \mathrm{~m}$ recovered $6.0 \mathrm{~m}$; therefore, the water depth was established at $1357.1 \mathrm{mbrf}$.

Spud-in at Hole 866B was in $27 \mathrm{~m}$ of soft nanno-foram ooze and was uneventful except for the string pounding bottom at times. The DCB cut 13 cores at Hole $866 \mathrm{~B}$ in 4.67 rotation hours. Recovery was $80 \%$ from punch coring with the DCB system in soft nanno-foram ooze. Recovery was $5 \%$ in hard, vuggy wackestone; however, hard-rock recovery was still 5 times better with the 
Leg 143

Preliminary Report

Page 69

DCB diamond bit than with the 9-7/8-in. RBI C-4 4-cone RCB insert bits. The bit cleared the seafloor at $0100 \mathrm{hr}, 25$ April, ending Hole 866B.

\section{HOLE 867A}

The success of the DCB system in improving recovery at Hole $866 \mathrm{~B}$ encouraged an attempt to spud-in on a hard reef-top site at Hole 867A. The ship was moved $1 \mathrm{nmi}$ north in DP (dynamic positioning) mode with the drill string hanging in the rotary.

The DCB failed on Hole 867A after spudding-in on a hard, bare reef top and coring $10.0 \mathrm{~m}$ in 1.42 rotation hours. Special care was exercised to spud-in with minimum WOB and rotary; however, the spud-in was very slow and difficult, with ledges and/or fill causing the string to pound bottom and the torque to be highly erratic.

The DCB BHA was pulled on Hole 867A when an obstruction $10 \mathrm{~m}$ above the bit (probably the dropped core) was followed by irregular pump pressure (from the parted bit sub). Only $0.07 \mathrm{~m}$ of core was recovered. The top four 6-3/4-in. drill collars had belled (flared) boxes from overtorquing (probably from wobbling while rotating unsupported in compression to activate the heave compensator on spud-in). The bottom pin of the core barrel parted (typical circumferential stress crack), leaving the Longyear carbonado diamond bit and bit sub in the hole.

\section{HOLE 867B}

The ship was moved $20 \mathrm{~m}$ east. The bit was a 9-7/8-in. RBI anti-whirl PDC (polycrystalline diamond compact) bit that had been rebuilt by RBI (after Leg 136-Hawaii) and used for the Amoco Catoosa bit test. The seafloor was an irregular, hard, bare manganese/phosphorite limestone surface at $1363.2 \mathrm{mbrf}$. Special care was exercised during spud-in; however, the spud-in was slow and difficult, with ledges and/or fill causing the string to pound bottom and making the torque highly erratic.

RCB (PDC) Cores 867B-1R to -14B were taken from 1363.2 to $1440.0 \mathrm{mbrf}$ (0.0-76.8 mbsf) with $76.8 \mathrm{~m}$ cored in 18.4 rotating $\mathrm{hr}$. Recovery averaged $29.17 \%$ in hard manganese/phosphorite 
Leg 143

Preliminary Report

Page 70

reef top and reefal/lagoonal limestones with laminated cave fill and stalagmites. (Note: Recovery with the RCB 4-cone insert bits was about $15 \%$ in similar lithologies.) Short, hard core sections jammed in the plastic core liner, reducing recovery on nearly a third of the cores. Coring parameters were 10-15K lb WOB, 30-100 rpm, 200-300 gpm, and 1-375 amps torque. The bit appeared to fall about $9 \mathrm{~m}$ in a cavern (?) and a very soft section from 24.5 to $52.5 \mathrm{mbsf}$, and the ROP was $28-55 \mathrm{~m} / \mathrm{hr}$. The normal ROP was $1.33-5.89 \mathrm{~m} / \mathrm{hr}$ (4.17 overall ROP).

The cores were of such interest that a decision was made to attempt to log the very shallow hole with short logging-tool assemblies (to get close to bottom). The hole was conditioned to log from 20 mbsf because the hard reef top would restrain the pipe. The PDC bit did not have a large enough bore for logging and could not be released (no MBR was run to maintain a stiff, strong bit/bit sub connection, and because the bit was experimental); therefore, a trip and reentry were required.

A FFF could not be used because the hard, bare reef top had virtually a 9-7/8-in. gage hole diameter; therefore, the 16-in. or 11-3/4-in. FFF casing stem would not fit in the hole. A 5-ft-tall 24-in. diameter hole marker pipe (junk VIT (vibration isolated television) guide) with a 30-in. funnel rim was painted with stripes, and a float and floating 3-m polypropylene rope were attached. The marker pipe was dropped, and a TV inspection found the marker pipe upright on the seafloor over the hole. The beacon on the VIT frame also locked in the offset coordinates of the hole for exact reentry positioning. The PDC bit was pulled, an 8-1/4-in. reentry/logging bit was run, and Hole 867B was reentered.

The logs were run without the wireline heave compensator (because the hole was so shallow) as follows:

Log no. 1: NGT/LSS/TCC. Logs were recorded down from 16.3 to $76.5 \mathrm{mbsf}$ and up from 76.5 to the seafloor. There was $0.3 \mathrm{~m}$ fill.

Log no. 2: TCC/DIT/NGT. Logs were recorded both up and down from 16.3 to 76.5 mbsf.

Log no. 3: NGT/CNT/TCC/HLDT. Two passes were recorded from 76.2 to $16.3 \mathrm{mbsf}$. 
Leg 143

Preliminary Report

Page 71

Log no. 4: TCC/GPIT/FMS/NGT. Two passes were recorded from 74.3 to $16.3 \mathrm{mbsf}$. There was no fill.

After logging, the reentry bit was pulled, clearing the seafloor at $1630 \mathrm{hr}, 27$ April. The ship was moved $400 \mathrm{~m}$ north in DP mode with the TV on bottom for a visual survey of the limestone surface. The irregular rough coral surface (at Hole 867B) gave way to a smooth, gentle slope with a 30-m drop onto a series of 6-ft-wide flat, rectangular manganese-coated phosphorite limestone slabs with 1-ft-wide ooze- and sand-filled cracks and shallow troughs on the outer reef (Hole 868A).

\section{HOLE 868A}

A Datasonics model 354B recall beacon, S/N 757, $17.0 \mathrm{kHz}$, was dropped at $1700 \mathrm{hr}, 27 \mathrm{April}$, commencing Hole 868A (Hue-B). Despite obvious dulling, spalling, and wear to the PDC cutters and slow ROP, the good recovery with the PDC bit on Hole 867B led to a second test on Hole 868A. The PDC bit was run with the same BHA for Hole 868A. The seafloor was tagged at $1396 \mathrm{mbrf}$, and Hole 868A was spudded at $2330 \mathrm{hr}, 27 \mathrm{April}$. The spud-in was on hard, bare reef top with $0-10 \mathrm{~K} \mathrm{lb}$ WOB and $20-30 \mathrm{rpm}$ to control erratic torque. PDC Cores $868 \mathrm{~A}-1 \mathrm{R}$ to $-5 \mathrm{R}$ were cut from 1396.0 to $1416.3 \mathrm{~m}(0.0-20.3 \mathrm{mbrf})$ in hard limestone with $46.31 \%$ average recovery. Core jamming in the plastic core liners was noted in nearly half the cores. Short cores were taken because of the jamming and with slow ROP (average $0.67-1.03 \mathrm{~m} / \mathrm{hr}$ ).

Coring was terminated at $0200 \mathrm{hr}, 29$ April, due to time limitations, and the PDC bit was pulled, clearing the rotary table at $0900 \mathrm{hr}, 29$ April, ending Hole 868A.

\section{TRANSIT FROM RESOLUTION GUYOT TO WODEJEBATO (SYLVANIA) GUYOT}

A 56-nmi seismic survey was run at $6 \mathrm{kt}$ over Resolution Guyot using one 200-in 3 water gun. Two 200 -in ${ }^{3}$ water guns were run on the final 14-nmi crossing.

A 255-nmi high-speed seismic survey was run at $10 \mathrm{kt}$ over the Mid-Pacific Mountains using one 200 -in ${ }^{3}$ water gun. The cooling water system was shut down for $6 \mathrm{hr}$ to repair a leak. A 345-nmi 
Leg 143

Preliminary Report

Page 72

transit was made to near Wodejebato Guyot, and a 196-nmi high-speed seismic survey was run at 10 kt over Wodejebato Guyot. A 23-nmi seismic survey was run at $5.4 \mathrm{kt}$ over site Syl-3. A Datasonics model 354B recall beacon, S/N 759, $14.0 \mathrm{kHz}$, was dropped on site Syl-3 at $0635 \mathrm{hr}$, 3 May. The signal became intermittent, so a backup beacon was dropped at $0845 \mathrm{hr}, 3 \mathrm{May}$.

\section{HOLE 869A}

Hole $869 \mathrm{~A}$ was sited on a sediment apron built during volcanism and reef development on the adjacent guyot and atoll; therefore, the $\mathrm{APC} / \mathrm{XCB}$ coring system was chosen to maximize recovery in soft carbonate sediments and reefal debris. An 11-7/16-in. APC/XCB bit was run. The PDR was at $4842.4 \mathrm{~m}$.

Core $869 \mathrm{~A}-1 \mathrm{H}$ was fired from $4838.0 \mathrm{~m}$, and the $9.5-\mathrm{m}$ shot recovered $9.69 \mathrm{~m}$; therefore, the water depth was established at $4837.8 \mathrm{mbrf}$ (the top of the core was very soupy). Cores $869 \mathrm{~A}-1 \mathrm{H}$ through $-9 \mathrm{H}$ were shot from 4837.8 to $4923.5 \mathrm{~m}(0.0-85.7 \mathrm{mbrf})$ with $85.7 \mathrm{~m}$ cored and $89.28 \mathrm{~m}$ recovered for $104.12 \%$ recovery in nannofossil radiolarian ooze and brown clay. The next core stood-up with no penetration or core recovery; therefore, XCB coring was initiated. Cores 869A10X through -18X were taken from 4923.5 to $5004.3 \mathrm{~m}(85.7-166.5 \mathrm{mbsf})$ with $80.8 \mathrm{~m}$ cored and $39.99 \mathrm{~m}$ recovered for $49.49 \%$ recovery in hard porcellanite chert, soft chalk, and brown clay. The XCB bit on Core 869A-18X made $1.0 \mathrm{~m}$ in $0.92 \mathrm{hr}$ and was worn down 1/4-in.; therefore, $\mathrm{XCB}$ coring was terminated. The bit cleared the rotary table at $2330 \mathrm{hr}, 4$ May, ending Hole 869A.

\section{HOLE 869B}

The ship was moved $30 \mathrm{~m}$ east, and an RCB BHA was run. The PDR indicated a water depth of $4843.4 \mathrm{mbrf}$, so the water depth for Hole $869 \mathrm{~A}$ was accepted (4837.8 mbrf). The bit was washed to 140.0 mbsf, and wash Core $869 \mathrm{~B}-1 \mathrm{~W}$ was retrieved. RCB Cores $869 \mathrm{~B}-2 \mathrm{R}$ to $-69 \mathrm{R}$ were taken from 4977.8 to $5634.0 \mathrm{~m}$ (140.0-796.2 mbsf) with $656.2 \mathrm{~m}$ cored and $252.04 \mathrm{~m}$ recovered (38.41\%) in hard porcellanite chert, soft chalk, and clay grading to volcaniclastic sands, breccias, and calcareous claystones. 
Leg 143

Preliminary Report

Page 73

At $333 \mathrm{mbsf}$, a wiper trip was made to $100 \mathrm{mbsf}$ to condition the hole through the 150 -m chert and clay interval that had been cored.The ROP slowed appreciably below $333 \mathrm{mbsf}$, and recovery was poor from 352 to $420 \mathrm{mbsf}$ because of soft brittle clay crumbling, compacting-in, and plugging the bit throat, core catcher, and core-liner throat. The drill string was plugged after the inner barrel was pulled and was cleared either by pumping (four times) or dropping the pipe deplugger (at 362 and $429 \mathrm{mbsf})$.

No swelling clays were encountered, but the clays did dissolve into fine particles in contact with fresh water. The $50 \%$ seawater $/ 50 \%$ freshwater-gel viscous mud sweeps were circulated completely out of the hole (based on pump and differential hydrostatic pressure) to avoid causing the hole to react. Viscous mud sweeps were gradually increased from $20 \mathrm{bbl} \mathrm{every} \mathrm{fourth} \mathrm{core} \mathrm{at}$ $227 \mathrm{mbsf}$ to 50 bbl every core near TD. Some core-catcher "lathing" and "discing" of soft clays and sands occurred sporadically.

Clays were encountered again from 564 to $603 \mathrm{mbsf}$, causing the core barrel to become plugged. The deplugger was dropped twice at 584 and $603 \mathrm{mbsf}$. After hole-cleaning problems and tight hole (80K OP) were encountered at $614 \mathrm{mbsf}$, another wiper trip was made at $642 \mathrm{mbsf}$.

Coring was halted at $796.2 \mathrm{mbsf}$ when time ran out, so a wiper trip was made to $100 \mathrm{mbsf}$, the MBR was released, and the sleeve was closed. The bit was pulled up to $90 \mathrm{mbsf}$ to log:

Log no. 1: LTL/NGT/SDT/CNT/HLDT/DIT. The HLDT was erratic and was changed out. The tool was run in to $778.2 \mathrm{mbsf}$ and recorded up, requiring $7.75 \mathrm{hr}$.

Log no. 2: NGT/FMS. The tool was run in to $128.2 \mathrm{mbsf}$, where it would not pass through a 12-in.-diameter hole in a chert ledge with washouts above in soft ooze. The Schlumberger engineer saw the magnetometer exit the drill pipe (but did not check the GR (gamma ray) to verify the tool was moving) and gave the OK to run-in the hole, which coincided with a relatively inexperienced winch operator coming on duty at a crew change. About $800 \mathrm{~m}$ of cable was slacked-off on the tool before stopping, which badly kinked the cable and loosened the armor. The drum had $8062 \mathrm{~m}$ of logging cable, and $750 \mathrm{~m}$ was cut off, leaving $7312 \mathrm{~m}$ on the drum. The spare spool has $9240 \mathrm{~m}$. The drill pipe was run in to 148 mbsf to get past the chert ledge. After the cable was reheaded, the FMS tool was rerun, 


\section{Leg 143}

Preliminary Report

Page 74

but the tool was again unable to pass the chert ledge. The pipe was run in to $234.8 \mathrm{mbsf}$, and the FMS tool was run successfully to $774.2 \mathrm{~m}$. The log required $23.5 \mathrm{hr}$.

The chert ledges proved not to be a problem for the longer $(32 \mathrm{~m})$, heavier $(1700 \mathrm{lb})$ combo tool, but the 12-m-long, 400-lb FMS tool was not long enough to be centralized by upper ledges or heavy enough to negotiate the rugose chert ledges.

Log no. 3: Magnetometer. The tool recorded from $727.2 \mathrm{mbsf}$ and required $6.0 \mathrm{hr}$.

Log no. 4: GST/ACT/CNT/LTL/NGT (geochemical). The log was recorded from $562.2 \mathrm{mbsf}$ in the remaining $7.5 \mathrm{hr}$ of logging time.

The drill string was treated with corrosion inhibitor and pulled, clearing the rotary at 1930 hr, 15 May (ending Hole 869B).

\section{TRANSIT FROM WODEJEBATO (SYLVANIA) GUYOT TO ANEWETAK ATOLL}

The sea voyage to Anewetak Atoll covered $136 \mathrm{nmi}$ in $15.0 \mathrm{hr}$ at an average speed of $9.1 \mathrm{kt}$. Seismic and magnetometer data were obtained en route.

\section{HOLE 870A}

The primary purpose of the Anewetak engineering test was to determine if the ship could continue coring while rotating into current and weather and maintaining position on the taut-wire system. Anewetak lagoon was entered through the east passage at $0855 \mathrm{hr}, 16$ May (low tide at $1116 \mathrm{hr}$ ). A site was selected in the mouth of the south passage in $38 \mathrm{~m}$ water depth (PDR). The taut-wire was lowered with a 2-drum anchor $(2000 \mathrm{lb})$ at $1055 \mathrm{hr}$. The ship was stabilized on the taut-wire and ASK (automatic station keeping) gains were adjusted for stability by $1258 \mathrm{hr}$. The ASK system was found to be capable of holding location to $3 \%$ of water depth in the fore/aft axis and to $4 \%$ in the port/starboard axis. The current averaged $1 / 2 \mathrm{kt}$, but was highly variable in strength and direction (the site location is in a tidal channel).

A shallow-water beacon with a low-power, wide-angle signal was considered the ideal backup for the taut-wire system, because the ship could temporarily position on the beacon in the event of 
Leg 143

Preliminary Report

Page 75

taut-wire problems and when turning the ship through wide angles. A shallow-water beacon was not available; therefore, a Datasonics $354 \mathrm{~b}$ beacon, $18.0 \mathrm{kHz}, \mathrm{s} / \mathrm{n} 750$, was modified with a $12-\mathrm{v}$ battery to give a 195-db signal and dropped at $1258 \mathrm{hr}$ near the taut-wire. The strong signal saturated the hydrophones on high variance. The beacon was recalled and recovered at $1400 \mathrm{hr}$. Testing resumed on the ASK performance until $1630 \mathrm{hr}$, when testing was initiated to determine how well the ship could turn into current and weather using the taut-wire. Some 5-1/2-in. transition pipe was run, and it tagged a firm seafloor at $49.8 \mathrm{mbrf}$ ( $38.6 \mathrm{mbsl})$. A heading change test was conducted with the taut-wire while turning $70^{\circ}$ starboard and $45^{\circ}$ port. The test demonstrated the ability to change heading into weather and current using only the taut-wire.

An 11-7/16-in. APC/XCB bit was run, and Hole 870A (Ane-1) was spudded at $2015 \mathrm{hr}, 16 \mathrm{May}$. APC Core $870 \mathrm{~A}-1 \mathrm{H}$ was taken from 49.8 to $50.0 \mathrm{~m}(0.0-0.2 \mathrm{mbsf})$ and recovered $0.19 \mathrm{~m}$ of coral, carbonate sand, and shell fragments. The core was checked for radiation but was clean. Core $870 \mathrm{~A}-1 \mathrm{H}$ did not stroke fully and had negligible penetration; therefore, APC coring was terminated.

\section{HOLE 870B}

The ship was moved $5 \mathrm{~m}$ north to avoid moving the taut-wire, and Hole $870 \mathrm{~B}$ was spudded with the XCB system at $2200 \mathrm{hr}, 16$ May. XCB Core $870 \mathrm{~B}-1 \mathrm{X}$ was taken from 48.7 to $61.1 \mathrm{~m}(0.0-$ $12.4 \mathrm{mbsf}$ ) with $0.10 \mathrm{~m}$ of hard, vuggy coral recovered. At $2345 \mathrm{hr}$ the ASK system lost heading, and the yellow caution light ( $10 \%$ of water depth) was lit. The bit was pulled out of the hole as a precaution. The excursion was apparently caused by an abrupt change in current at slack tide. The ship was quickly repositioned, and (to avoid repeating the spud-in) Hole 870B was reentered at $0000 \mathrm{hr}, 17$ May, by rolling the bit off into the washout crater. Cores $870 \mathrm{~B}-2 \mathrm{X}$ to $-3 \mathrm{X}$ were taken from 61.1 to $80.0 \mathrm{mbrf}$ (12.4-31.3 mbsf) with $0.31 \mathrm{~m}$ of hard coral recovered. The coring parameters were: $5-10 \mathrm{~K} \mathrm{lb}$ WOB, $40-45 \mathrm{rpm}, 150-300 \mathrm{gpm}$, and torque of $125-150 \mathrm{amps}$. The cores were checked for radiation, and none was found.

The hole was extremely unstable and filled in rapidly. Hole conditions were too bad to continue drilling; however, the taut-wire system was still holding the ship stable on location. The bit was pulled, clearing the seafloor at $0315 \mathrm{hr}, 17$ May, and the rotary at $0430 \mathrm{hr}$, ending Hole 870B. Anewetak Atoll was exited via the south pass with $36 \mathrm{ft}$ of clearance. 
Leg 143

Preliminary Report

Page 76

\section{SEA VOYAGE FROM ANEWETAK ATOLL TO MAJURO ATOLL}

Having been advised that an oil tanker would take our dock in Majuro from approximately

$1000 \mathrm{hr}, 20 \mathrm{May}$, to $1000 \mathrm{hr}, 21 \mathrm{May}$, the ship proceeded directly to Majuro. The ship docked in Majuro at approximately $1200 \mathrm{hr}, 19$ May 1992, ending Leg 143. 


\section{LEG 143 OPERATIONS SUMMARY}

Water Water Number Interval Recovered Percent Interval Total Time

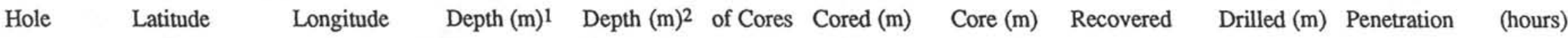

\begin{tabular}{|c|c|c|c|c|c|c|c|c|c|c|c|}
\hline $865 \mathrm{~A}$ & $18^{\circ} 26.410^{\prime} \mathrm{N}$ & $179^{\circ} 33.339^{\prime} \mathrm{W}$ & 1529.1 & 1518.4 & 94 & 870.90 & 132.07 & 15.16 & 0.0 & 870.90 & 159.00 \\
\hline $865 \mathrm{~B}$ & $18^{\circ} 26.415^{\prime} \mathrm{N}$ & $179^{\circ} 33.349^{\prime} \mathrm{W}$ & 1527.0 & 1516.2 & 19 & 165.50 & 123.66 & 74.72 & 0.0 & 165.50 & 26.25 \\
\hline \multirow[t]{2}{*}{$865 \mathrm{C}$} & $18^{\circ} 26.425^{\prime} \mathrm{N}$ & $179^{\circ} 33.339^{\prime} \mathrm{W}$ & 1528.2 & 1517.4 & 15 & 136.30 & 114.11 & 83.72 & 0.0 & 136.30 & 12.75 \\
\hline & SITE ALL-A & TOTALS & & & 128 & 1172.70 & 369.84 & 31.54 & 0.0 & 1172.70 & 198.00 \\
\hline $866 \mathrm{~A}$ & $21^{\circ} 19.953^{\prime} \mathrm{N}$ & $174^{\circ} 18.844^{\prime} \mathrm{E}$ & 1372.6 & 1361.8 & 189 & 1743.60 & 268.98 & 15.43 & 0.0 & 1743.60 & 406.00 \\
\hline \multirow[t]{2}{*}{$866 \mathrm{~B}$} & $21^{\circ} 19.952^{\prime} \mathrm{N}$ & $174^{\circ} 18.870^{\prime} \mathrm{E}$ & 1357.1 & 1346.1 & 13 & 117.40 & 23.06 & 19.64 & 0.0 & 117.40 & 17.50 \\
\hline & SITE HUE-A & TOTALS & & . & 202 & 1861.00 & 292.04 & 15.69 & 0.0 & 1861.00 & 423.50 \\
\hline $867 \mathrm{~A}$ & $21^{\circ} 20.963^{\prime} \mathrm{N}$ & $174^{\circ} 18.550^{\prime} \mathrm{E}$ & 1363.2 & 1352.2 & 1 & 10.00 & 0.07 & 0.70 & 0.0 & 10.00 & 10.50 \\
\hline \multirow[t]{2}{*}{$867 \mathrm{~B}$} & $21^{\circ} 20.959^{\prime} \mathrm{N}$ & $174^{\circ} 18.561^{\prime} \mathrm{E}$ & 1363.2 & 1352.2 & 14 & 76.80 & 22.47 & 29.26 & 0.0 & 76.80 & 49.50 \\
\hline & SITE HUE-B & TOTALS & & & 15 & 86.80 & 22.54 & 25.97 & 0.0 & 86.80 & 60.00 \\
\hline \multirow[t]{2}{*}{$868 \mathrm{~A}$} & $21^{\circ} 21.171^{\prime} \mathrm{N}$ & $174^{\circ} 18.564^{\prime} \mathrm{E}$ & 1396.0 & 1384.9 & 5 & 20.30 & 9.40 & 46.31 & 0.0 & 20.30 & 40.00 \\
\hline & SITE HUE-B' & TOTALS & & & 5 & 20.30 & 9.40 & 46.31 & 0.0 & 20.30 & 40.00 \\
\hline $869 \mathrm{~A}$ & $11^{\circ} 00.091^{\prime} \mathrm{N}$ & $164^{\circ} 44.969^{\prime} \mathrm{E}$ & 4837.8 & 4826.7 & 18 & 166.50 & 129.27 & 77.64 & 0.0 & 166.50 & 41.00 \\
\hline \multirow[t]{2}{*}{$869 \mathrm{~B}$} & $11^{\circ} 00.093^{\prime} \mathrm{N}$ & $164^{\circ} 45.019^{\prime} \mathrm{E}$ & 4837.8 & 4826.7 & 69 & 656.20 & 252.04 & 38.41 & 140.0 & 796.20 & 260.00 \\
\hline & SITE SYL-3 & TOTALS & & & 87 & 822.70 & 381.31 & 46.35 & 140.0 & 962.70 & 301.00 \\
\hline $870 \mathrm{~A}$ & $11^{\circ} 20.829^{\prime} \mathrm{N}$ & $162^{\circ} 15.788^{\prime} \mathrm{E}$ & 49.8 & 38.6 & 1 & 0.20 & 0.19 & 95.00 & 0.0 & 0.20 & 10.75 \\
\hline \multirow[t]{2}{*}{$870 \mathrm{~B}$} & $11^{\circ} 20.833^{\prime} \mathrm{N}$ & $162^{\circ} 15.775^{\prime} \mathrm{E}$ & 48.7 & 37.5 & 3 & 31.30 & 0.41 & 1.31 & 0.0 & 31.30 & 6.75 \\
\hline & SITE ANE-1 & TOTALS & & & 4 & 31.50 & 0.60 & 1.90 & 0.0 & 31.50 & 17.50 \\
\hline & LEG 143 & TOTALS & & & 441 & 3995.00 & 1075.73 & 26.93 & 140.0 & 4135.00 & 1040.00 \\
\hline
\end{tabular}

1Seafloor depths given in meters from the driller's datum at the dual elevator stool (DES).

2 Seafloor depths given in meters below sealevel (mbsl). 
Leg 143

Preliminary Report

Page 78

\section{Leg 143 Time Distribution}

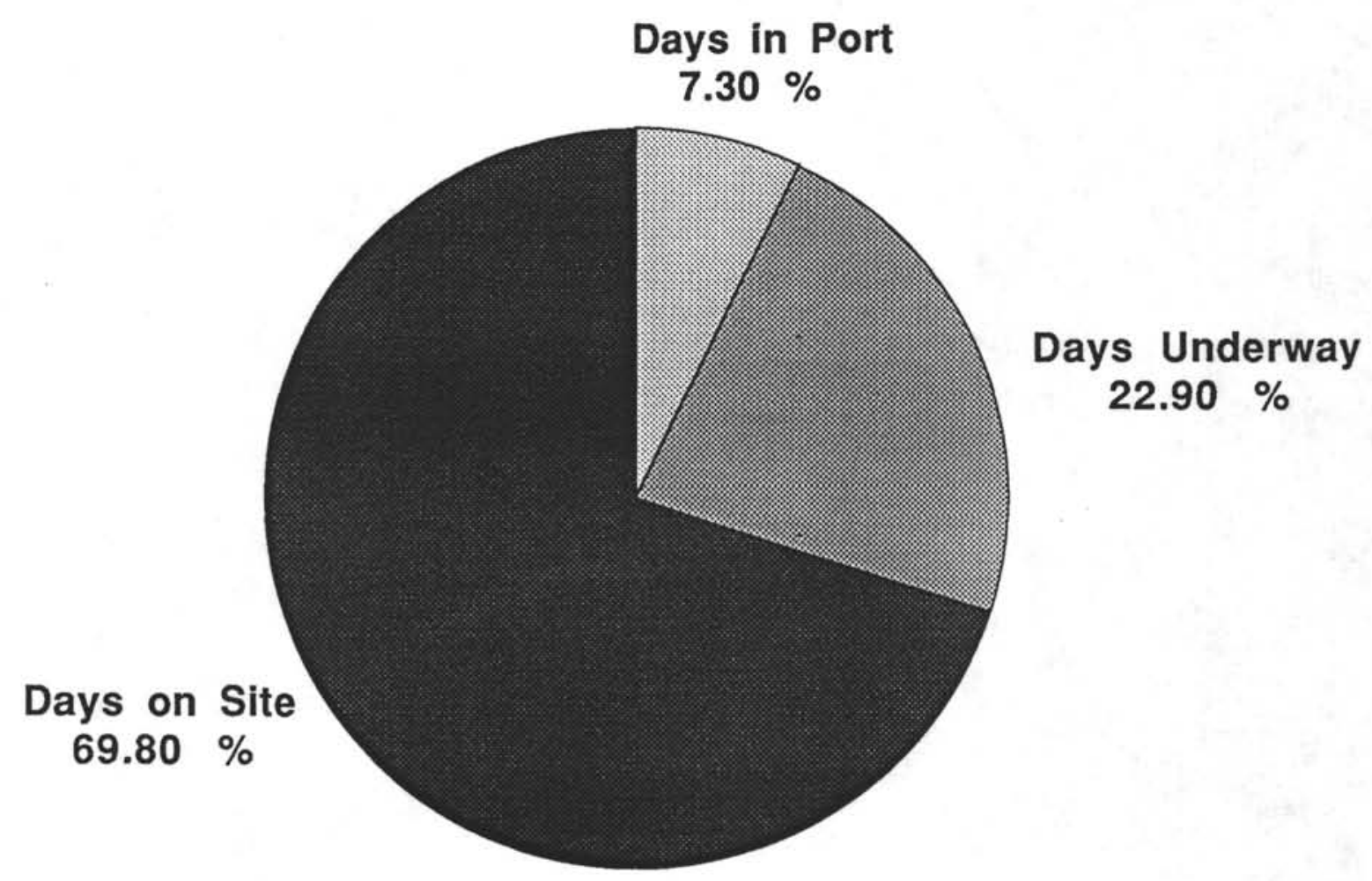


TECHNICAL REPORT 
Leg 143

Preliminary Report

Page 80

The ODP Technical and Logistics personnel aboard JOIDES Resolution for Leg 143 were:

$\begin{array}{ll}\text { Roger Ball } & \text { Electronics } \\ \text { MaryAnn Cusimano } & \text { X-ray } \\ \text { Edwin Garrett } & \text { System Manager } \\ \text { "Gus" Gustafson } & \text { Assistant L.O., Thin Section, DHT (WSTP), Fantail } \\ \text { Michiko Hitchcox } & \text { Yeoperson } \\ \text { Brad Julson } & \text { Lab Officer } \\ \text { Robert Kemp } & \text { Underway Geophysics } \\ \text { Ken McCormick } & \text { Chemistry } \\ \text { Jean Mahoney } & \text { Physical Properties } \\ \text { Jeff Millard } & \text { Storekeeper } \\ \text { Shan Pehlman } & \text { Photographer } \\ \text { Chieh Peng } & \text { Chemistry } \\ \text { Don Sims } & \text { Assistant L.O., FMS, DHT (WSTP) } \\ \text { Lorraine Southey } & \text { Curatorial Representative } \\ \text { Bill Stevens } & \text { Electronics, DHT (Adara) } \\ \text { Monica Sweitzer } & \text { Paleomagnetics } \\ \text { Barry Weber } & \text { System Manager }\end{array}$


Leg 143

Preliminary Report

Page 81

\section{SCIENTIFIC OBJECTIVES OF LEG 143}

Legs 143 and 144 constitute an integrated campaign of drilling Cretaceous carbonate-bearing guyots of the Western Pacific, with the objective of using them as monitors of relative sea-level changes and thereby of the combined effects of the tectonic subsidence (and uplift) history of the seamounts and of global fluctuations of sea level. By comparing records from widely separated guyots, tectonic effects may be separable from eustatic effects. Cores from the volcanic edifices under the limestone cap are providing data for estimating the paleolatitude of formation of the guyots and for assessing the long-term history of the Dupal isotopic anomaly in the Pacific.

\section{PORT CALL, HONOLULU}

The ship arrived in Honolulu on 18 March 1992, a day ahead of schedule. The offgoing crew immediately started unloading the DCS equipment. The oncoming crew arrived at the ship the morning of 19 March 1992. Because this is a U.S. port, there was a large schedule of events planned. After an extensive crossover, the DCS equipment continued to be taken off the ship. The removal of the equipment and packing it into containers and onto flatbeds took the rest of the port call. Divers were used to remove an isolation transformer from the sonar dome located on the ship's hull. This transformer was relocated to the forward thyrig room and temporarily fixed the problems with the $3.5-\mathrm{kHz}$ transducer. A dock crane was used to lift a levelwind to the starboard side of the fantail. The base was cut off and the levelwind welded to the deck just aft of the starboard winch. The photocopiers in the library and the main deck were replaced with new units. The old units were crated and sent off with the offgoing shipments. In the photolab, the old Wing Lynch processor was removed and a new processor set up in its place. A new "Seaphone" was installed in the conference room of the library. Unfortunately the installation team did not have the boards to connect the telephone to the MARISAT system. These boards were to have arrived at Majuro, making the system functional. There was an extensive microscope cleaning. It took most of the port call; all the scopes were cleaned, repaired, and realigned. There was a liquid-helium refill of the cryogenic magnetometer. Both Chuck Helsley and Bill Goree of $2 \mathrm{G}$ assisted. There was a Digital Equipment Corp. service call and a Shipboard Measurements Panel meeting. SMP met with the specialists from the different labs and discussed the equipment and methods of analysis. There were many tours by Hawaii Institute of Geophysics (HIG) students and staff as 
Leg 143

Preliminary Report

Page 82

well as TAMRF personnel. Also, several of the HIG staff and H. Hoskins brought a Sun computer aboard to test compatibility with our underway-geophysics system for use during Leg 146. The ship sailed the afternoon of 22 March 1992

\section{LAB OPERATIONS}

\section{Underway/Fantail}

We collected Geophysical data on five transit lines. Bathymetry and magnetics were collected routinely, and seismic gear was towed on all transits, except that from Anewetak to Majuro. The seismic gear was towed at $10.5-11$ kt. Two 80 -in. ${ }^{3}$ water guns were towed from Hawaii to the first site, and on the subsequent lines we used a single 200 -in. ${ }^{3}$ water gun. Due to a problem with the ship's compressors, we didn't have enough compressed air to use the second 200 -in. ${ }^{3}$ water gun simultaneously.

During the port call, divers removed the isolation transformer for the $3.5-\mathrm{kHz}$ transducer from the sonar dome. The transformer was replaced with a spare and permanently installed on the forward bulkhead of the forward thyrig room. The system worked again for about 3 days before it developed problems of alternating light and dark bands across the records. Attempts to troubleshoot were unproductive. In order to ensure decent $3.5-\mathrm{kHz}$ records, the Raytheon transceiver and processor were set up, and the aft $3.5-\mathrm{kHz}$ transducer array was used. It worked well over the shallow guyots. Troubleshooting of the EDO transceiver and booster revealed several problems, which were fixed by the ETs. Subsequent testing reveals that there is still a problem with the $3.5-\mathrm{kHz}$ transducer in the sonar dome.

Sonobuoys were used again after a hiatus of several years. Seven runs were produced from the sonobuoys. All sonobuoy tapes were recorded with two channels on HIGHRES. The sonobuoys use different frequencies to transmit their data. Each frequency corresponds to a different channel, and we received a complete listing of these channels.

A new GPS antenna was installed, and we requisitioned a new memory board as backup to the ailing memory board. The flutes on the lower stem of the Doppler sonar were modified to allow it 
Leg 143

Preliminary Report

Page 83

to be lowered through the gate valve and into position beneath the ship. Calibration and tests were performed.

There was routine maintenance performed on all the fantail gear, and XBTs were routinely dropped while on transits.

\section{Chemistry Lab}

Routine shipboard chemistry analyses were performed during the leg. Interstitial water was analyzed. Due to the amount of limestone recovered, it was difficult to extract pore water. A leaching method was used on samples that were too indurated to squeeze. Distilled water was added to the samples and then squeezed out again and analyzed. A new Eager 200 program was received for the NCHS instrument. This program is a noticeable improvement from its predecessor. It is very easy for the user to recalculate amounts if the user decides to change the calibration method or remove bad calibration points. A couple of new versions of LOTUS 1-2-3 for Windows arrived, and scientists can now easily transfer files between EXCEL and LOTUS $1-2-3$ on the MACs or PCs.

The new GEOFINA hydrocarbon meter (GHM) that was installed on Leg 141 was extensively tested this leg. A method was developed on LAS that used our standards as well as standards brought out by the geochemist. Calibration curves were developed for the $S_{1}$ and $S_{2}$ bulk peaks. Chromatographs were also obtained for the material in the individual $S_{1}$ and $S_{2}$ bulk peaks. This allows the investigator to identify the individual components in each of these bulk peaks.

A new hydrogen generator was received and installed as a replacement for the aging Milton Roy.

\section{$\underline{\text { X-Ray Lab }}$}

Few samples were analyzed on the XRF, but there was a lot of troubleshooting needed to keep both goniometers up and running well. One of the goniometers was calibrated during the leg and was used to analyze the samples. By the end of the leg, both goniometers appeared to be working again. Parts have been ordered to replace the damaged pieces. 


\section{Leg 143}

Preliminary Report

Page 84

The XRD was used quite a bit during the leg. A new CD ROM was installed on the PC486, and Philip's Total Access Diffraction Database (TADD) software was loaded. This program allows the user to identify minerals in the XRD trace. It is not user friendly, but the specialists are slowly learning how to use the program. The tube was changed in the XRD. A telex was received asking us not to use the alumina ceramic and agate shatter box rings and pucks because they are brittle and have been damaged lately.

\section{Thin Section Lab}

Over 420 thin sections were made of limestones, siltstones, basalt, and volcaniclastics. Due to the nature of the material, thin sections were vital for age dating the carbonates and limestones. The varicut saw was moved to the core lab to help the physical properties scientists cut parallel minicore faces.

\section{Paleontology Lab}

The paleo lab had a new, larger oven installed answering past suggestions that this lab needed more oven room for drying samples. The oven was never used this leg. Ducting to the HF fume hoods had deteriorated. The remnants were removed, and new ducting was ordered.

\section{Physical Properties Lab}

There were two scientists and a new specialist who learned the lab very quickly. Vertical and horizontal minicores were taken for one of the scientists. Two new printers were added to the lab. New thermcon thermistor needles were mounted and calibrated. The disc on the PC for the MST was defragmented, which decreased the time it took to save data.

\section{Paleomagnetics Lab}

This is the first leg on which the changes in the core lab and magnetics lab could be tried out. The magnetics lab worked quite well. The leg began with a liquid-helium refill of the cryogenic magnetometer. Bill Goree of $2 \mathrm{G}$ helped with the transfer and answered questions. A cardboard wall was constructed between the photo area and this lab to keep the photo flash from blinding 
Leg 143

Preliminary Report

Page 85

the scientists. A new oscilloscope was hooked up to the GSD to check the output and input of the AF demagnetizer. A Haskris heat exchanger, which uses the ship's chill water, was installed in the lab. This unit will be used to cool the compressor for the cryogenic magnetometer. This will give us more control of the cooling of the cryogenic magnetometer; if the ship's chill-water system is shut off, then the Haskris unit can be run using regular ship's water. The multishot core orientation tool was also used on most APC cores.

\section{Core Lab}

This was the first leg to recover significant amounts of core with the new core lab configuration. The modifications were completed on the way to the first site with the installation of three new cabinets and table tops along the outside bulkheads of the starboard side of the core lab. The aft end of this area is the future site of the core-integration area. The area just across from the description table is the future home for the split core MST. Microscopes and computers were distributed on both bench tops. The auxiliary sampling table was continuously used for labeling hard rocks and as a place to keep the cores waiting for the other shift. Thin-section billets were taken from the cores as soon as the cores came up so that thin sections could be quickly made for rapid age determination. A new Felker saw was set up, and a new plexiglass shield was made for it. Much of the core consisted of small amounts of limestone, and this was curated in a manner similar to that for hard rock.

\section{Computers}

All the PC computers were upgraded to DOS version 5.0 and Wordperfect for Windows. Thin-net ethernet was extended to the upper 'Tween decks and the downhole tools lab. We had a number of problems with MAC IIx boards, which had soldered batteries on the main boards. When the computer was turned off, there was not enough power to activate the electronic on/off switch. We got around the problem by jump-starting the computer, using another motherboard that had a working battery. This was the first time that Email was tried on an experimental basis. It is still in a testing and development phase. It had been requested by many previous scientists and was well received. A separate LO archive volume was created, using the MAC si's internal drive in the system manager's office. The LO files were transferred from the DRAKE SHARE VOLUME, so DRAKE SHARE is now used exclusively for data collection and distribution. 
Leg 143

Preliminary Report

Page 86

\section{Curatorial}

The shipboard scientific party selected cores representing each lithology encountered on Leg 143 and left these aboard for display purposes for the Leg 144 shipboard scientific party. A significant number of whole rounds were taken for a post-cruise macrofossil (rudist bivalve) study. These will be returned to the Gulf Coast Repository after being studied.

\section{Downhole Tools}

The WSTP water-sampling tool was used in conjunction with the last remaining Uyeda recorder. A water sample was collected, but the temperature measurement failed. Troubleshooting determined that there was a short caused by seawater in the thermistor probe tip. Thermistors are on order.

\section{Miscellaneous}

The entire lab stack and all the equipment were shut down for about 3 hours during the cruise in order to patch the main salt-water line that runs over the top of the gym.

A new core-catcher bench with a sink was made by the welders and installed on the catwalk with plans made for air and water to be piped to it. A new lock was placed on the table saw to limit access to trained personnel and three new acid cabinets were installed and filled on the upper 'Tween deck.

Damaged ceiling tiles were replaced throughout the lab stack as needed. 
Leg 143

Preliminary Report

Page 87

\section{Lab Statistics: Leg 143}

\section{General Statistics:}

Sites

Holes

12

Cored Intervals (m)

3995.0

Core Recovered (m)

1075.73

Total Penetration (m)

4135.0

Number of Samples:

Samples Analyzed:

Inorganic Carbon $\left(\mathrm{CaCO}_{3}\right)$

Total Carbon (NCHS)

Water Chemistry (the suite includes $\mathrm{pH}$,

Alkalinity, Sulfate, Magnesium, Calcium,

Chlorinity, Potassium, Ammonia, Silica)

Gas Samples

Thin Sections

XRD

$\mathrm{XRF}$

Majors

Traces

MST Runs

Cryomagnetometer Runs

856

Oriented Runs

Physical Properties Velocity

300

Thermal Conductivity

100

Index Properties

600

Underway Geophysics:

Bathymetry (nmi)

3390

Magnetics (nmi)

Seismics (nmi)

\section{Downhole Tools:}

WSTP 